\title{
A diplomacia da americanização de Salvador de Mendonça (1889-1898)
}

\author{
Gabriel Terra Pereira
}

\section{SciELO Books / SciELO Livros / SciELO Libros}

PEREIRA, GT. A diplomacia da americanização de Salvador de Mendonça (1889-1898) [online]. São Paulo: Editora UNESP; São Paulo: Cultura Acadêmica, 2009. 178 p. ISBN 978-85-7983-006-8. Available from SciELO Books $\langle$ http://books.scielo.org $>$.

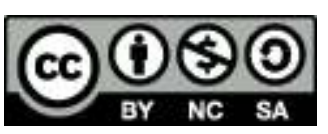

All the contents of this chapter, except where otherwise noted, is licensed under a Creative Commons Attribution-Non Commercial-ShareAlike 3.0 Unported.

Todo o conteúdo deste capítulo, exceto quando houver ressalva, é publicado sob a licença Creative Commons Atribuição Uso Não Comercial - Partilha nos Mesmos Termos 3.0 Não adaptada.

Todo el contenido de este capítulo, excepto donde se indique lo contrario, está bajo licencia de la licencia Creative Commons Reconocimento-NoComercial-CompartirIgual 3.0 Unported. 


\section{A DIPLOMACIA DA AMERICANIZAÇAO DE SALVADOR DE MENDONÇA (1889-1898)}

GABRIEL TERRA PEREIRA 
A DIPLOMACIA DA AMERICANIZAÇÃO DE SALVADOR DE MENDOnÇA (1889-1898) 



\section{GABRIEL TERRA PEREIRA}

\section{A DIPLOMACIA DA AMERICANIZAÇÃO DE SALVADOR DE MENDONÇA (1889-1898)}


(C) 2009 Editora UNESP

\section{Cultura Acadêmica}

Praça da Sé, 108

01001-900 - São Paulo - SP

Tel.: (0xx11) 3242-7171

Fax: (0xx11) 3242-7172

www.editoraunesp.com.br

feu@editora.unesp.br

CIP - Brasil. Catalogação na fonte

Sindicato Nacional dos Editores de Livros, RJ

P491d

Pereira, Gabriel Terra

A diplomacia da americanização de Salvador de Mendonça (18891898) / Gabriel Terra Pereira. - São Paulo : Cultura Acadêmica, 2009.

Inclui bibliografia

ISBN 978-85-7983-006-8

1. Mendonça, Salvador de, 1841-1913. 2. Brasil - Relações internacionais - 1889-. 3. Brasil - Relações exteriores - Estados Unidos - História. 4. Estados Unidos - Relações exteriores - Brasil - História. 5. Brasil Política e governo, 1889-. I. Título.

09-6047.

CDD: 327.81

CDU: $327(81)$

Este livro é publicado pelo Programa de Publicações Digitais da Pró-Reitoria de Pós-Graduação da Universidade Estadual Paulista "Júlio de Mesquita Filho" (UNESP)

Editora afiliada:

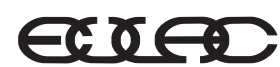

Asociación de Editoriales Universitarias de América Latina y el Caribe

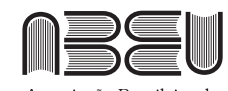

Associação Brasileira de Editoras Universitárias 
Para meus pais. 



\section{Agradecimentos}

Este livro não é fruto de um esforço individual. Muitas foram as pessoas que, ao longo de pouco mais de dois anos, nos indicaram caminhos, auxiliaram, ouviram, discutiram e aconselharam. E nem sempre essas atitudes ocorrem com a contrapartida do bom humor e da paciência. O que está escrito nas dezenas de páginas que compõem este trabalho tem, portanto, muito do sentimento alheio.

Sou extremamente grato à professora doutora Teresa Malatian, que me acompanha desde a graduação. Suas sugestões e seus ensinamentos combinados com o profissionalismo acabaram por sempre me dar segurança no que escrevia e propunha. O estímulo intelectual que me fez chegar ao presente momento se deve muito a ela. Agradeço também a todos os funcionários da Unesp, campus Franca, pela atenção e educação no tratamento aos alunos. Aos professores doutores Mariza Saenz Leme e Samuel Alves Soares, agradeço pelas sugestões e críticas ao trabalho.

Agradeço à Fundação de Amparo à Pesquisa do Estado de São Paulo (Fapesp), que, por meio da bolsa de pesquisa, me proporcionou os recursos indispensáveis à manutenção do projeto e às viagens necessárias ao enriquecimento profissional.

Nesses anos, o apoio de minha família e de meus amigos foi vital. Meus pais, Jademir e Maria Inês, e meus irmãos, Letícia e João 
Marcos, demonstram que nossa união cresce a cada dia, ouvindo, aprendendo e crescendo juntos. Sem eles, este trabalho não teria sentido. $\mathrm{O}$ agradecimento se estende a meu avô e minha avó, tios, tias e primos. São essas - muitas - pessoas que me lembram a cada dia da exata noção da palavra saudade.

Aos amigos presentes e ausentes, devo muito das conversas em momentos difíceis, permeados de dúvida e às vezes de insegurança. À Élidi, pelos sentimentos felizes construídos ao longo dos anos da graduação e pós-graduação. Ao Augusto, pela convivência tranquila e divertida, fazendo-me lembrar do irmão que tenho longe da casa de meus pais. Ao Rafael Prianti, pela profundidade com que consegue tocar os sentimentos das pessoas, sugerindo e apontando caminhos. Ao David, pelo companheirismo e pela força cada vez maiores para comigo.

Por fim, agradeço à universidade pública, gratuita e de qualidade. Formado em suas fileiras, compartilho com essa instituição o que me proporcionou: o conhecimento. Muito obrigado. 
"É apenas isto: se você vai ser humano, tem um monte de coisas no pacote. Olhos, um coração, dias e vida. Mas são os momentos que iluminam tudo. $\mathrm{O}$ tempo que você não nota que está passando... é isso que faz o resto valer."

Neil Gaiman 



\section{SUMÁRIO}

Introdução 13

1 O advento da República e a ação de Salvador de Mendonça 23

2 Relacionamento Brasil-Estados Unidos 67

3 A consolidação da República 107

Considerações finais 169

Referências bibliográficas 173 



\section{INTRODUÇÃO}

Segundo Eric Hobsbawm (1998, p.87-95), em obra referencial, era muito provável que no final do século XIX o ritmo de crescimento da economia mundial, determinado pelos núcleos desenvolvidos ou em desenvolvimento do capitalismo, viesse a ser "um mundo de império". O período compreendido entre os anos de 1875 e 1918 delimitou a inauguração, o auge e a decadência de um tipo de imperialismo visto como produto do capitalismo industrial voltado para a obtenção de matérias-primas e produtos agrícolas em geral, combinados com a expansão de mercadores consumidores.

Um dos significados desse imperialismo surgia da contradição entre as dimensões dos Estados nacionais europeus e as exigências do desenvolvimento produtivo decorrentes do início da produção em massa que instavam por novos mercados, com início na década de 1870. A acentuação dessa contradição, também o motor desse imperialismo, foi o crescente protecionismo econômico dos países dependentes dos europeus, desencadeando uma série de choques entre estes e - por exemplo - Inglaterra, França e Alemanha, que procuraram conquistar e resguardar novos mercados por todo o mundo, prevalecendo a tendência em assegurar o controle político direto ou indireto dos territórios vinculados a eles o mais amplamente possível (Bobbio et al., 2007, v.1, p.618-9). 
O processo foi sentido por todo o mundo e assumiu peculiaridades de acordo com a formação política e cultural de cada região em que ocorreu, ao contrário da dominação formal de países europeus sobre africanos e asiáticos, onde as hostilidades ante o indivíduo estrangeiro crescia rapidamente. No continente americano (com exceção dos Estados Unidos), a influência dos países desenvolvidos podia ser considerada informal à medida que aumentavam os negócios e as transações de empresas, participando na industrialização e na circulação de mercadorias, barateando o custo e facilitando o acesso a elas. No entanto, essa ligação cada vez mais forte entre os países não possuía um sentido restrito à economia. Os interesses econômicos também serviam diretamente como instrumento para atingir desígnios políticos, decorrendo desse objetivo uma série de choques que extrapolaram a retórica diplomática, culminando em conflitos armados como a Primeira Guerra Mundial, que matou milhões de pessoas. O frágil pilar de sustentação desse mundo era representado pelo imperialismo gestado no século XIX, que havia engendrado a dependência econômica e a fragilidade dos regimes políticos dos países que sofreram sua ação, somados à disputa interna entre os próprios europeus pela dominação direta ou indireta nessas regiões (Renouvin \& Duroselle, 1967, p.80).

Nesse cenário, observa-se que no Brasil as práticas imperialistas remodeladas não atingiram o País homogeneamente, mas foram sentidas em um momento importante de sua história enquanto Estado independente: a transição da Monarquia para a República.

Os representantes políticos do Brasil vinham, desde a segunda metade do século XIX, quando o País atravessava uma fase de crescimento econômico, relutando em abolir o trabalho escravo e forçando a permanência de estruturas econômicas e políticas que impediam maior entrada de capitais estrangeiros, além de restringir o estreitamento de laços com países vizinhos. No sentido contrário, grupos descontentes convergiram suas forças pela desestabilização do regime monárquico, utilizando o descontentamento momentâneo para arregimentar radicais e propagandistas em suas fileiras. $\mathrm{O}$ agravamento da contestação ao regime político e às crises internas, 
como a campanha pelo abolicionismo e sua concretização em maio de 1888, somado às transformações econômicas no sistema internacional, conduziram à fragilização da Monarquia, que pereceu em 1889.

A partir da configuração desse cenário, o presente trabalho elegeu como enfoque a noção de política externa como desdobramento da política interna, tratando-as como planos intercambiáveis (Milza, 2003, p.365-6). Dessa forma, o entendimento sobre o período torna-se mais rico, apresentando perspectivas diferentes, mas que sintetizam o funcionamento do Estado brasileiro e as ideias e práticas que o fundamentavam.

Essa operação insere-se no que se convencionou chamar de "retorno da história política" ou "nova história política", capitaneada pelo historiador francês René Rémond, que enxerga uma nova roupagem para tal perspectiva historiográfica, distinta da visão construída pelo grupo formado em torno da revista dos Annales. O entendimento de Rémond é o de que o campo político não possui limites ou é algo inflexível; nele não existem fronteiras naturais. Articulado intimamente com a ação estatal, o campo político se contrai e se dilata de acordo com necessidades econômicas, culturais ou sociais de cada país, figurando como uma poderosa força de expressão coletiva e condensação das práticas dos indivíduos, ao contrário da visão da tradicional história factual e exclusivamente elitista (Rémond, 2003b, p.443). ${ }^{1}$ Portanto, a nova história política contempla novos atores e novas abordagens, permitindo, ao fim, o surgimento de novos objetos de pesquisa. Essas ideias, além de revisitarem a definição de história (e) política, não podem ser entendidas sem a ideia de aproximação; aproximação esta de caráter epistemológico, efetivada pela prática da interdisciplinaridade.

O notável trabalho de Gabriela Nunes Ferreira (2006, p.17) pinça precisamente a questão, justificando que a abordagem do campo político desdobrado no plano interno e externo é fundamental para sua compreensão, além de alertar para os perigos de uma análise unilateral:

1 A noção de coletivo abordada aqui se restringe aos indivíduos ligados ao poder político, ou seja, aqueles que trabalham na esfera estatal. 
[...] a maioria dos estudos que enfocam episódios envolvendo relações internacionais tende a desvincular a análise da política externa dos países estudados da análise de suas respectivas estruturas e conjunturas políticas internas. Também não examinam de perto os recursos de poder internos (capacidade de promover alianças políticas, poder econômico, etc.) mobilizados na relação com outros países. $\mathrm{O}$ mais grave é que tal perspectiva traz em si o risco do anacronismo, já que muitas vezes trata como Estados prontos Estados em formação, empenhados ainda em firmar a ordem interna.

Outra importante noção apresentada neste trabalho é a ideia de campo político, retirada da obra de Pierre Bourdieu (2003, p.140-2) que analisa a estruturação do poder simbólico. ${ }^{2}$ Ao desenvolver a noção de campo atrelado ao poder simbólico, Bourdieu procura compreender o funcionamento das práticas sociais e dar significado às disputas entre determinadas visões de mundo em uma sociedade. Nesse sentido, o campo é a representação do terreno onde ocorrem as lutas pela formação do poder simbólico, e elas podem ser percebidas nas esferas econômica, social, cultural ou política, e para cada uma, segundo Bourdieu, há um campo autônomo e específico em que se dão as lutas.

A intenção de se aplicar a noção de campo neste trabalho decorre do significado que o cenário em que acontecem as lutas possui na prática diplomática. Para tanto, utiliza-se a ideia de campo político, um universo em que o simbólico tem alta importância, pois nele residem as forças atreladas aos interesses do Estado, aparecendo ações e representações em disputa pela primazia na formulação da política interna e externa.

Essas "lutas", travadas simbolicamente por meio de discursos, ofícios ou mesmo militarmente, demarcam visões de mundo que são selecionadas e legitimadas umas em detrimento de outras. No caso

2 Sumariamente, o chamado "poder simbólico" na obra de Bourdieu (2003) pode ser encontrado nas relações de poder estabelecidas entre os indivíduos que as exercem (dominantes) e os que lhe estão sujeitos (dominados), podendo tais relações ser de ordem econômica, cultural ou política. 
do campo político brasileiro, o momento de transição do regime se mostra extremamente rico ao se analisar a produção dessas visões de mundo, revelando os traços peculiares da cultura política do período. Portanto, a utilização do conceito de campo político se mostra pertinente à medida que se procura descobrir o modus operandi e as intenções dos atores do período.

A escolha de tal instrumental metodológico corresponde a uma necessidade: a de apontar quais eram as especificidades do regime político brasileiro posterior a 1889 e de que forma a política exterior, por meio da diplomacia, contribuiu para a formação dessas características.

Nesse sentido, o primeiro passo dado na pesquisa foi buscar a origem desse republicanismo, que se deu no movimento de 1870 . O grupo republicano fora formado por indivíduos com uma trajetória e experiências comuns, alijados do status quo político. Com a formação do Clube Republicano no Rio de Janeiro em 1870, o movimento passou a se estruturar e ganhou as províncias do Império. Para os homens que o compunham, os objetivos a serem perseguidos eram bastante claros: pôr fim à única Monarquia americana e, em seu lugar, instaurar uma República federativa com ampla autonomia das províncias. A inspiração do movimento vinha de muitas fontes externas, mas era, sobretudo, o paradigma norte-americano que iluminava as palavras de oradores e defensores da implantação de uma República no Brasil: consideravam que a situação de excepcionalidade do Brasil no continente somente o prejudicava política e economicamente. A compreensão de que era preciso reformar as instituições brasileiras não passava despercebidamente pelos homens do Império, que chegaram a propor efetivamente mudanças no sistema político vigente, mas acabaram barrados pelas estruturas conservadoras alocadas há décadas no poder.

Em meio a tal cenário de surgimento do republicanismo no país, encontrava-se Salvador de Mendonça, que, no período de sua formação em São Paulo (1859-1869), havia entrado em contato, em um primeiro momento, com os liberais radicais, depois com os republicanos, passando à propaganda já no final da década de 1860 . 
Na década seguinte, ajudou a compor o Manifesto Republicano que se apropriava do discurso de James Monroe, presidente dos Estados Unidos, em 1823: "Somos da América e queremos ser americanos". 3

O percurso de Salvador de Mendonça foi significativamente alterado no momento em que foi convidado a se juntar à legação do Império brasileiro nos Estados Unidos, o que notadamente representaria uma contradição em suas convicções políticas. Instado pela boa oportunidade de ascensão social, foi para os Estados Unidos, de onde voltaria apenas em 1898, já sob o regime republicano. Durante o Império, sua atuação diplomática incidiu sobre a importância crescente que a economia norte-americana possuía para a brasileira, principalmente no comércio de café, de que os Estados Unidos eram os maiores compradores.

O segundo passo dado nesta pesquisa foi demarcar a atuação de Salvador de Mendonça no período republicano, no qual as ideias de republicanização e americanização foram tomadas como sinônimos no campo político brasileiro. O processo de construção desse "par político indissociável” se deu a partir de 1870, porém foi colocado em prática somente a partir de 1889. Sumariamente, são três os momentos representativos da atuação do diplomata brasileiro que evocam o já exposto, pano de fundo da aproximação entre Brasil e Estados Unidos.

O primeiro momento se deu na Conferência de Washington (1889-1890), que reuniu grande parte dos países americanos para discutir as possibilidades de uma integração comercial continental, além de outras questões atinentes ao Direito Internacional. O Brasil Império, que jamais havia se interessado por tal iniciativa, era representado no certame por Salvador de Mendonça e mais dois diplomatas: Amaral Valente e Lafaiete Pereira. Durante as negociações, houve a mudança de regime no Brasil, uniformizando o cenário político americano: o continente era majoritariamente composto por países que adotavam o regime republicano. Salvador de Mendonça, então, passou a negociar nos Estados Unidos o reconhecimento do

3 A célebre frase de Monroe: "A América para os americanos". 
novo regime brasileiro, instado pela circunstância de que nenhum país europeu o faria antes da "grande República norte-americana". No início de 1890, o reconhecimento foi obtido, e ao diplomata brasileiro foi dado o crédito pela ação.

O desenvolvimento do republicanismo no país e o despontamento de Salvador de Mendonça na diplomacia, somados às características do plano interno e externo do novo regime no momento de realização da Conferência de Washington, estão presentes no Capítulo 1 deste livro.

As decisões deliberadas no certame internacional de 1889-1890 não resultaram em ações práticas para grande parte dos países americanos, com exceção do Brasil, à medida que envolvia questões de Direito Internacional (o arbitramento obrigatório e a abolição do direito de conquista), uniformização de pesos e medidas e ações em prol da aproximação comercial entre os países americanos. ${ }^{4}$

Fragilizado economicamente pela mudança abrupta do regime, o país priorizava o respaldo político dos Estados Unidos, que, por sua vez, procuravam se aproveitar da situação para alargar seus mercados no Brasil. Nesse aspecto, tem-se o segundo momento de atuação de Salvador de Mendonça, por ocasião da assinatura do Tratado de Reciprocidade, em 1891. O acordo previa a exportação e importação de produtos entre os dois países com isenção de tarifas fiscais, com o fito de aumentar o comércio, e foi longamente criticado, pois as tarifas eram uma importante fonte de renda do Brasil. Perdê-las seria fragilizar ainda mais a economia do país. Salvador de Mendonça defendeu a assinatura do Tratado, pois acreditava que a saída de mercadorias do Brasil para os Estados Unidos supriria perdas decorrentes da não taxação da importação, acreditando inclusive em uma reativação da economia açucareira do Nordeste.

Conseguindo a aprovação do governo brasileiro, o diplomata assinou o Tratado, mas foi duramente pressionado por não fazer

4 O Brasil adotou na Constituição Republicana, em 1891, o princípio do arbitramento obrigatório e, como se verá neste livro, procurou aproximar-se dos Estados Unidos por meio do comércio e do regime político similar. 
constar uma cláusula de exclusividade para o açúcar brasileiro contemplado no acordo. A questão que gerou polêmica foi a assinatura de acordo comercial semelhante dos Estados Unidos com a Espanha, que forneceria, via sua colônia de Cuba, açúcar mais barato e de melhor qualidade que o do Brasil, anulando os benefícios defendidos por Salvador de Mendonça. O processo de negociação do Tratado e as críticas à aproximação com os Estados Unidos estão detalhados no Capítulo 2.

O terceiro momento diz respeito à intervenção estrangeira na Revolta da Armada, entre 1893 e 1894, no Brasil. Permeado de lutas internas pela preponderância no campo político, o país via seu primeiro presidente renunciar, e seu vice, Floriano Peixoto, enrijecer diante das contestações. O descontentamento da Marinha brasileira culminou com a Revolta que bloqueou o porto no Rio de Janeiro, paralisando o comércio. Tal ação fez agir as potências estrangeiras, que procuraram regulamentar o conflito doméstico sem sucesso. Nos Estados Unidos, a pedido do governo brasileiro, Salvador de Mendonça organizou outra esquadra e negociou a intervenção armada para pôr fim ao conflito. A despeito de relutâncias oficiais e da opinião pública, ocorreu a intervenção direta dos Estados Unidos no conflito, na qual o contra-almirante Benham alvejou embarcações brasileiras e conseguiu fraquejar as forças rebeldes, pondo fim ao conflito em 1894. Não faltaram críticas aos Estados Unidos e ao governo de Floriano Peixoto, acusado de ter arranhado a soberania do país.

Após o conflito, a produção de versões acerca da intervenção estrangeira (especialmente a norte-americana) marcou a luta por visões positivas e negativas da Revolta da Armada, procurando julgar as ações do governo de Floriano Peixoto. Tais discussões e a correspondência atinente ao conflito encontram-se no Capítulo 3.

Esses três momentos marcaram o segundo passo da pesquisa, que não se encerra com a atuação de Salvador de Mendonça na Revolta da Armada. Eles são fundamentais para a compreensão de que a política externa brasileira nos primeiros anos republicanos buscou referências nos Estados Unidos, alterando o polo político, econômico e cultural tradicionalmente construído pela monarquia: a Europa. E, 
nesse sentido, a diplomacia representada por Salvador de Mendonça foi um agente fundamental nesse processo de construção de um novo paradigma político. A atuação do diplomata foi em grande medida omitida e/ou minimizada pela historiografia produzida sobre o período, certamente um fruto das críticas subjacentes às suas polêmicas defesas em prol do relacionamento do Brasil com os Estados Unidos.

Nascido em Itaboraí, na província do Rio de Janeiro, em 1841, Salvador de Mendonça cresceu e foi educado no ambiente politizado da Corte. Seguindo a costumeira marcha dos filhos de famílias de posses durante o Império, foi a São Paulo para formar-se bacharel em Direito, em 1869. Na capital paulista, teve contato com liberais radicais, participou de suas agremiações e colaborou em periódicos, escrevendo artigos contra o poder pessoal do imperador. A volta ao Rio de Janeiro foi traduzida na dedicação ao jornalismo político, cada vez mais iluminado pelas cores do republicanismo, característica que chegou a se estender à via literária, por ocasião da publicação de romances e poemas. A longa carreira diplomática teve início em 1875 , nos Estados Unidos, de onde saiu somente em 1898, participando de momentos fundamentais para a história do Brasil. Sua carreira foi interrompida em 1898 depois de uma transferência malsucedida para a legação de Lisboa não aprovada pelo Congresso brasileiro. Em 1903, passou à disponibilidade, mas não chegou a representar mais o país por causa de problemas de saúde.

Com o escopo de promover seu próprio julgamento, publicou uma série de artigos transformados em livro, em 1913, ano de sua morte: A situação internacional do Brasil. Na obra, analisada ao longo deste livro, o ex-diplomata revisitava os momentos em que defendeu os interesses brasileiros e criticava severamente os condutores da política externa brasileira à época: Rio Branco e Joaquim Nabuco. Ele acreditava ser o membro fundador da diplomacia pró-Estados Unidos, ao contrário do que a imprensa disseminava na época a favor dos outros representantes brasileiros. Apesar da existência de críticas consistentes ao longo da obra, percebe-se que seu rancor em relação ao esquecimento sobrepunha-se à análise apurada do contexto internacional, gerando, assim, as críticas a Joaquim Nabuco e a Rio 
Branco, que, de uma forma ou de outra, atuavam em momento completamente distinto ao que Salvador de Mendonça havia trabalhado. A comparação acerca do "peso" de cada trajetória pode remeter ao anacronismo, mas foi a partir de 1889, na Conferência de Washington, que o Brasil procurou se aliar politicamente aos Estados Unidos, aprimorando o relacionamento durante as décadas seguintes.

A compreensão de que a política externa e a diplomacia contribuíram para moldar o campo político brasileiro entre 1889 e 1898, realizada por meio da leitura da correspondência diplomática, mostrou-se trabalho instigante, pois tais informações combinadas com a leitura da bibliografia e de obras do período expõem o quão frágil se revelava o campo político brasileiro no momento da transição do regime e como essa fragilidade se estendeu a determinados indivíduos, como Salvador de Mendonça, que foi lançado ao ostracismo após 1898. Foi a partir de 1898 também que se iniciou uma nova fase republicana no país: o governo de Campos Sales, que conseguiu apaziguar o campo político brasileiro aplicando a "política dos governadores". Na política externa, era o período de transição para a ascensão de Rio Branco ao cargo de ministro das Relações Exteriores, que formou um novo paradigma diplomático no país e no cenário internacional.

Este livro procura clarificar determinadas características do período, expondo, sobretudo, a porosidade entre as políticas interna e externa do país, e como o intercâmbio entre elas moldou a ação de um diplomata e caracterizou o regime proclamado em 1889. 


\section{1 \\ O ADVENTO da República e a AÇÃo de Salvador de Mendonça}

A mudança da Monarquia para a República no Brasil sempre foi alvo de interpretações acaloradas. Logo nos primeiros momentos do novo regime, já existiam diversas versões que reivindicavam a veracidade do processo, indicando os interesses, os grupos e os indivíduos que seriam exaltados ou execrados daquele momento em diante. Nesse sentido, há uma dupla consequência com a qual depara o historiador, a saber, um paradoxo: lidar com um grande número de fontes que podem enriquecer o trabalho de pesquisa, mas que trazem, ao mesmo tempo, visões de mundo parciais e fragmentárias, que concorrem para dificultar o estabelecimento da síntese necessária à compreensão do passado. Diante de tal realidade em que cada grupo explica a realidade à sua maneira, o historiador precisa procurar além dos fatos, estudando o que escapa à consciência dos contemporâneos (Costa, 1994, p.266-7).

Nesse sentido, o estudo da trajetória de Salvador de Mendonça, que ocupou o posto de diplomata do Brasil nos Estados Unidos durante o Império e sob a República, revela-se representativo. Atuando no campo da política externa, Mendonça esteve exposto a críticas durante toda sua carreira, motivando debates que expunham os conflitos entre as facções políticas nos anos republicanos (1889-1898). 


\section{O republicanismo no Brasil e o início da carreira diplomática de Salvador de Mendonça}

Antes de adentrar nos quadros da burocracia imperial, Salvador de Mendonça esteve ligado ao grupo de republicanos do Rio de Janeiro e de São Paulo que nortearam o movimento republicano na segunda metade do século XIX. Também acompanhou a crise do Império e a mudança do regime, processos políticos que tiveram como pano de fundo o desenvolvimento de uma visão de mundo sintonizada com o campo político e econômico dos Estados Unidos. Do período de fundação do Clube Republicano, em 1870, do qual Salvador de Mendonça era membro, à proclamação da República, em 1889, o movimento republicano assumiu diversas feições e graus de difusão na sociedade. Atraiu liberais radicais e militares descontentes, certamente pela capacidade de apontar um profundo desequilíbrio entre o poder político e o poder econômico, gerando demandas por reformas estruturais no Estado brasileiro.

Esse desequilíbrio fundamentava-se nas contradições que o próprio sistema político brasileiro possuía no desenrolar do século XIX, tal como a existência de um sistema carente de uma verdadeira representação e a persistência da mão de obra escrava como sustentáculo da economia do país. A existência do poder moderador e sua "pessoalidade" na distribuição de recursos entre as províncias levavam, por um lado, à manutenção dos traços de poder econômico e político construídos nas províncias ao longo do século XIX; por outro, perpetuavam a ausência participativa da maioria da população nos assuntos públicos, pautando a hierarquização da sociedade entre os que tinham acesso ou eram excluídos do campo político, ainda que houvesse representação por intermédio de deputados e senadores. A existência da mão de obra escrava, sistematicamente criticada após a década de 1850 e fortalecida na década de 1880 com o movimento abolicionista, sinalizava a urgência de mudanças estruturais de que carecia o País, dependente de uma "classe" de trabalhadores que tendia ao desaparecimento, seja pela pressão externa (inglesa) ou interna (opinião pública). 
A tais contradições somou-se a profunda transformação da economia brasileira em meados da década de 1850, quando novas atividades e investimentos estrangeiros adentraram o País, ocasionando maior diversificação do comércio, e impulsionaram relativa industrialização. Do choque entre o desenvolvimento econômico e as contradições do sistema político, saiu o grupo republicano, que representava a síntese do descontentamento em relação às dificuldades atravessadas pelo país. O grupo era formado pelos indivíduos que se situavam à margem do poder, ou seja, que não tinham acesso direto aos cargos e às posições de destaque na sociedade política imperial. No entanto, suas motivações não se justificavam unicamente pela vontade de participação política, mas também na possibilidade de, gradativamente, mudar o regime brasileiro da Monarquia para a República (Holanda, 2005, p.81-4).

A origem do movimento republicano remontava ao ano de 1868 , marco cronológico no agravamento desse desequilíbrio, quando o imperador destituiu o já eleito gabinete liberal para dar lugar aos conservadores, engendrando a formação de uma ala radical proveniente do grupo alijado da qual posteriormente saíram os primeiros republicanos (Lyra, 1964, p.81), ao mesmo tempo que as pressões externas pela substituição da mão de obra escrava cresciam forçando o debate no campo político (Pinto, 1984, p.137-8).

A preponderância conservadora na formação do gabinete imperial não estava desconectada ao todo das mudanças recentes da economia, pelo contrário, revelava um modo de atuação peculiar dos grupos no poder, constantemente utilizado: a capacidade de conciliação perante situações que lhes eram adversas, remetendo-se a uma tradição não escrita. A maioria dos grupos assentados no poder político possuía sustentação financeira suficiente para patrocinar medidas favoráveis à manutenção do status quo, implicando a legitimação tanto dos mecanismos de distinção social quanto da hierarquia existente. Tal ação acabava por fechá-los no campo político, barrando o acesso daqueles que não pactuassem o mesmo pensamento.

Para seus detentores, a organização da sociedade brasileira, calcada na diferenciação entre os que eram ou não livres, e entre estes 
os aristocratas, mostrava-se como um sinal afirmativo da herança cultural europeia que demarcava a organização social e política do Império. Quando havia situações que questionavam a exclusividade brasileira quanto ao seu regime político no continente, por exemplo, evocavam-se a ligação estreita do imperador e do Brasil com a Europa e a "superioridade" adjacente ao comportamento do indivíduo europeu, civilizado e fortemente ligado às suas tradições (Alonso, 2002, p.78).

Apesar de esse comportamento permear a atuação política de parlamentares e conselheiros imperiais durante parte do século XIX, o que de fato marcou o período de destituição do gabinete liberal e da fundação do Clube Republicano no Rio de Janeiro em 1870 foi exatamente o descumprimento dessa tradição imperial, que deu margem ao surgimento de reivindicações radicais acerca da organização das eleições, da autonomia das províncias e da excessiva autoridade do imperador. Em outras palavras, houve um agravamento das disputas políticas no seio do Estado que não permitiu que o equilíbrio com o setor econômico voltasse à normalidade, ocasionando sua própria ruína em novembro de 1889.

A facção radical dos liberais foi organizada de forma independente e ainda mantinha suas ligações com o regime monárquico, conforme expunha Saldanha Marinho, cinco vezes eleito deputado e presidente das províncias de Minas Gerais e de São Paulo. Marinho também era jornalista, profissão de importância no grupo que utilizava a imprensa como meio de criticar os gabinetes imperiais e suas atitudes, como na Guerra com o Paraguai (1865-1870), que, para esses indivíduos, representava o quão despreparado e frágil era o contingente militar brasileiro diante de tão grave situação. A crise já existente foi adensada pelos próprios militares que, ao fim da guerra, passaram a reivindicar mais atenção do Estado. Eles se ressentiam da contínua redução de seu contingente, de seus salários cada vez mais baixos e das escassas verbas concedidas à manutenção de seu material. Assim,

Depois da guerra, muitos oficiais brasileiros não ficaram satisfeitos em retornar ao antigo padrão de um Exército menor e menos 
conspícuo. O Exército sentia-se enganado por políticos civis tanto durante quanto depois da Guerra e ficou mais propenso a questionar a ordem. De acordo com um observador simpatizante contemporâneo, o que retornava vitorioso "já não era aquele Exército de uma passividade absoluta" dos dias anteriores à guerra. Depois de suportarem "privações de toda espécie", eles encontraram a "ingratidão" do governo. Os militares estavam prontos a "discutir os atos dos governos prepotentes", como eles haviam aprendido a fazer na região do Prata (Hahner, 1975, p.26-7).

Diante de tamanhas turbulências, foi fundado o Clube Republicano no Rio de Janeiro, em dezembro de 1870. Entre seus fundadores, estavam Saldanha Marinho, Quintino Bocaiúva, Aristides Lobo, Lopes Trovão e Salvador de Mendonça, que, com exceção do primeiro, não faziam parte das hostes imperiais. ${ }^{1}$ Eram jovens jornalistas com formação em Direito ou em Medicina que procuravam aproveitar as oportunidades apresentadas pela conjuntura política e ampliar esferas de influência e reconhecimento social, fertilizando o terreno para a crise por meio da propaganda escrita e de discursos públicos (Alonso, 2002, p.51, 162). A existência de um clube com rótulo republicano criava uma estratégia de diferenciação identitária em um cenário polarizado por dois partidos políticos tradicionais, criando meios de canalização das reivindicações dos setores descontentes com a política imperial e aprimorando ideias que orientaram seu comportamento até a queda da monarquia. Contudo, em 1870 não se "inaugurava" o movimento republicano com uma grande obra política, pois a maioria dos integrantes do clube era composta por jovens recém-formados e inexperientes, além do que a ideia não era arraigada no campo político brasileiro: sua revitalização era fruto de uma radicalização política (Lyra, 1964, p.54). O movimento republicano da década de 1870 era o produto do descontentamento dos

1 Saldanha Marinho foi presidente das províncias de Minas Gerais, entre 1865 e 1867, e de São Paulo, entre 1867 e 1868, além de eleger-se deputado pelo Rio de Janeiro (1861-1866) e pelo Amazonas (1878-1881). 
radicais liberais que fizeram críticas objetivas ao poder moderador e ao imperador, que os havia destituído do poder em 1868 (Alonso, 2002, p.100-5).

O espaço de atuação do grupo era inicialmente o Rio de Janeiro, centro das atenções internas e externas do país, que sobrepunha o comércio, a política e a intelectualidade da época, tornando-a singular: na cidade localizava-se o Parlamento, as legações estrangeiras e a grande imprensa, que formava uma opinião pública não partidária. Desse lócus urbano, emergiu o grupo republicano que, a partir de 1870, se esforçaria em criticar a decadência do Império e de D. Pedro II, delineando o início do processo de remodelagem da cultura política existente.

As transformações dos anos 1870 fincaram uma cunha na história política do Segundo Reinado. A modernização material do país e a decadência das instituições centrais do Império feriram o coração da obra saquarema, abrindo uma crise apenas concluída com a queda do regime. Tinham sinalizado as possibilidades de mudança e identificado precisamente obstáculos a ela: o apego às formas de um mundo em dissolução, como bem ilustra o costume de Itaboraí de seguir de coche ao Senado quando os jovens deputados tomavam o bonde; um reacionarismo destituído de projeto, a alimentar-se de uma economia morta (Alonso, 2002, p.95).

Foram essas brechas que os indivíduos da década de 1870, marginalizados pela elite política, souberam aproveitar. A incompletude das reformas conservadoras, que tentaram em vão aproveitar-se do período de prosperidade, e uma inédita mobilidade social, ainda não absorvida pelo Estado, abriram perspectivas de alianças e permeabilidade do sistema político, possibilitando tanto o acesso de indivíduos marginalizados politicamente quanto o debate de questões fora do horizonte possível do Império. Essa trajetória comum autorizava a formulação de um repertório ou ainda de formas de pensar e agir articuladas com as lutas políticas desse contexto. O grupo fundador do Clube Republicano possuía essa feição emergente, pois não era 
decorrente do tradicional meio de aristocratas do Império, que formavam quase que um estamento senhorial. Assim, investiram suas forças na crítica ao regime político, aperfeiçoando seus argumentos proporcionalmente à difusão de suas ideias.

Foi organizado o periódico intitulado A República, que serviria à causa republicana, do qual saiu em sua primeira edição, em três de dezembro de 1870, o Manifesto do Clube, amplamente conhecido, redigido por Quintino Bocaiúva e Salvador de Mendonça (Bandeira, 1973, p.120). No texto, ficava exposto o principal foco de atuação do grupo: a necessidade de reformas que deveriam abranger toda a sociedade, sustentadas basicamente pela ideia de federação, o que, em outras palavras, significava dar autonomia às províncias muitas vezes obstaculizadas pelo excesso de controle da Corte, que centralizava suas arrecadações e sua administração. Sua simplicidade argumentativa tocava no ponto defendido por certos segmentos liberais que viam parte de sua plataforma política lapidada e identificada com o republicanismo. Apesar de ser a carta ideológica do movimento inaugurado, o Manifesto de 1870 não compunha um programa político-partidário. Era mais um ensaio histórico com fragmentos de teoria política combinados com os pecados da Monarquia, trazendo o republicanismo como uma alternativa à sua decadência (Boehrer, s. d., p.216-7). Nesse primeiro momento, tanto o federalismo quanto a República eram ideias advogadas pelos republicanos a serem conquistadas por vias eleitorais no Parlamento e sem mudanças abruptas no campo político brasileiro. $\mathrm{O}$ abolicionismo não fazia parte do programa republicano, pois, em suas fileiras, figuraram grandes fazendeiros escravocratas. Nesse sentido,

O movimento intelectual da geração de 1870 não foi nem popular nem revolucionário. Foi reformista. [...] Os contestadores negavam a forma violenta do exemplo de mudança mais tenazmente brandido no Império: a Revolução Francesa. Apostaram na propaganda e na persuasão. [...] Embora elitista, o movimento intelectual recorreu a uma estratégia inédita no Segundo Reinado: a mobilização coletiva fora das instituições políticas (Alonso, 2002, p.262). 
Tal mobilização possuía e comportava novas formas de pensar, fruto do diálogo com novas ideias advindas do exterior e traduzidas à realidade brasileira: o ímpeto reformista, ao contrário das revoluções que há pouco tempo assombravam a burguesia europeia, no Brasil era o sinal afirmativo para aqueles que desejavam galgar os degraus do espaço político, ou seja, alcançar o poder, ainda que por vias não convencionais. Decorria dessa ambição tácita a crítica severa ao poder moderador, incompatível com a soberania do povo, porém adequado à nobreza e à sacralidade do imperador, que, na visão dos republicanos, era inviolável e isento de responsabilidades. A ele eram atribuídos os grandes males da centralização política (Azêdo, 1975, p.69-70).

O Manifesto e o jornal A República constituíram a primeira realização importante do republicanismo no Brasil. ${ }^{2}$ Com o formato objetivo, o Manifesto conseguiu ampla popularidade no Rio de Janeiro, logo também pelas províncias de São Paulo, Minas Gerais, Rio Grande do Sul e Pernambuco, chegando à circulação de dez mil exemplares, um marco para o grupo que apenas iniciava suas atividades sob a bandeira do republicanismo. A propaganda subjacente a ele, desenvolvida em comícios e conferências públicas e principalmente por meio da imprensa, contribuiu para criar em certos meios intelectuais uma opinião pública favorável à ideia republicana que, no decorrer das décadas de 1870 e 1880, adaptou-se às especificidades regionais (Costa, 1994, p.331).

Na província de São Paulo, a trajetória desse republicanismo foi de fundamental importância para o movimento em nível nacional. Organizados, os paulistas conseguiram, logo nos momentos iniciais, que no texto do Manifesto fosse contornado o problema da escravidão, pois alguns de seus representantes eram grandes proprietários de cativos. Em São Paulo, republicanismo e abolicionismo não eram causas complementares, e, dessa maneira, foi adotada uma solução

2 Para Sérgio Buarque de Holanda (2005, p.139), o rótulo de radical, ligado aos liberais, não faz mais sentido já no início da década de 1870, pois a fundação do Clube Republicano marcava o rompimento com o campo político tradicionalmente composto por liberais e conservadores. 
conciliadora: os republicanos não se opunham à ideia da escravidão, mas também não se pronunciavam contra ela. O problema da escravidão era para eles considerado social e não político, algo que admitia soluções regionais e descentralizadoras, cabendo aos proprietários resolver acerca de sua mão de obra e de sua incorporação na sociedade. Paradoxalmente, a deliberação do grupo republicano era mais política do que social (Lyra, 1964, p.83-5; Boehrer, s. d., p.73-6).

A província de São Paulo era, noutro sentido, historicamente importante para o movimento republicano: muitos de seus representantes haviam se formado na tradicional Faculdade de Direito da capital e, depois, retornado à Corte. Era o caso de Salvador de Mendonça, que se mudou em 1859, entrou em contato com os segmentos radicais do partido liberal e ingressou no jornalismo político, retornando ao Rio de Janeiro para compor com Bocaiúva, Marinho e Aristides Lobo o Clube Republicano em 1870.

Em São Paulo, a ascensão da lavoura de café como força motriz da economia provincial encontrou na centralização monárquica o impedimento para o desenvolvimento urbano e material de suas camadas dominantes. Os estudantes, que vivenciavam os choques entre a elite da província e o governo central, viram na propaganda radical o meio para formar sua visão de mundo e descarregar as críticas ao Império, que parecia "impedir o progresso" do País. Desse cenário, a propaganda radical evoluiu com rapidez para o tom republicano.

A imprensa republicana da província possuiu ao longo de duas décadas periódicos representativos, como a A Província de São Paulo, que oscilava entre a declaração formal de não ser republicana, porém defendendo a completa descentralização administrativa, e o apoio sem limites à plataforma do partido republicano estadual, fundado em 1873 na Convenção de Itu. Em 1876, surgia, por iniciativa dos estudantes de Direito, o periódico A República, homônimo do Clube do Rio de Janeiro e que trazia em seus textos a defesa da via evolucionista, advogando a chegada ao regime republicano por meios eleitorais. No final da década de 1880, chegou inclusive a defender a separação de São Paulo do País caso a pressão centralizadora dos gabinetes imperiais persistisse. O movimento republicano em São 
Paulo tornou-se significativo porque havia atingido a posição de partido, era rígido quanto à disciplina e forte em unidade, ao contrário do Rio de Janeiro, onde o grupo era pequeno e limitado quanto às forças políticas (Boehrer, s. d., p.89-119).

Em Minas Gerais, o movimento não se mostrou tão forte como em São Paulo, mas, por causa de sua importância política junto ao Império, foi um espaço de visibilidade das reivindicações republicanas, conseguindo enviar à Câmara dos Deputados, Joaquim Felício dos Santos, um dos poucos republicanos eleitos no período monárquico. Logo após a publicação do Manifesto do Clube carioca, diversas publicações de tendência liberal e radicais se converteram ao republicanismo, como o periódico O Jequitinhonha. A figura de destaque no período da propaganda republicana na província foi Lúcio de Mendonça, irmão de Salvador de Mendonça, que residiu por alguns anos em São Gonçalo do Sapucaí, exercendo o cargo de vereador. Lúcio possuía postura mais rígida quanto ao republicanismo: era contra qualquer tipo de aliança com os liberais e conservadores, pois tal atitude não era nada mais que o enfraquecimento e a desmoralização do republicanismo no país (Lyra, 1964, p.90-4).

No Rio Grande do Sul e em Pernambuco, o movimento republicano também adquiriu importância em contraste com as demais províncias. A imprensa, campo de debate privilegiado, contribuiu para que Francisco Cunha, Carlos Barbosa, Assis Brasil e Júlio de Castilhos formassem o Estado-maior do republicanismo gaúcho, ao ponto de constituírem, no final da década de 1880, o segundo grupo político da província, atrás somente dos conservadores. Em Pernambuco, despontaram as figuras de Silvio Romero e Tobias Barreto, que partiam de uma teoria evolutiva da sociedade e da política, solapando e criticando a dominação dos conservadores (ibidem, p.95-100). Ambos defendiam a República como a forma moderna de governo e apostavam na criação de uma elite ilustrada para implementar as reformas necessárias ao estabelecimento gradual do regime no País (Alonso, 2002, p.221-2). Mas, como no Rio Grande do Sul, em Pernambuco o republicanismo foi comprometido pela diversidade de posicionamentos políticos, variando entre temas gerais: o 
positivismo, o abolicionismo e o federalismo. Nesse sentido, a fragmentação de ideias contribuiu para enfraquecê-los regionalmente, ainda que em âmbito nacional tais dissensões tendessem somente a avolumar as críticas à Monarquia.

Oito anos após a publicação do Manifesto Republicano, subiu ao poder o gabinete Sinimbu, o primeiro desde a ação interventiva de D. Pedro II em 1868, que contribuiu para o descontentamento liberal e a formação do grupo republicano. A propaganda republicana nesse momento vinha marcada pelas diversas alterações nos cargos diretivos dos órgãos de imprensa dos partidos provinciais, como o ocorrido no Rio de Janeiro com A República, que em 1872 passou das mãos de Quintino Bocaiúva para as de Salvador de Mendonça e outros jornalistas. Bocaiúva vinha sendo sistematicamente atacado por colegas e adversários políticos por tornar o jornal do clube, agora partido, ${ }^{3}$ uma propriedade privada, impedindo a manifestação de outras tendências do republicanismo. De fato, até 1878 muito se tentou para unir os republicanos do País que não hesitavam em preterir diretrizes de uma "União Republicana Federal" proposta por Quintino em favor de necessidades locais, como notadamente o fizeram os paulistas. As divergências internas do partido fizeram alguns de seus membros retornarem às hostes do Império, como foi o caso de Lafaiete Rodrigues Pereira, que integrou o gabinete Sinimbu como ministro da Justiça e que comprometia os republicanos quanto às alianças que haviam feito (Lyra, 1964, p.87; Boehrer, s. d., p.38-9). Era o período de recrudescimento do movimento republicano com novas características, que iria sair de um período de quase dez anos de letargia. Durante todo esse período, não só as disputas internas pela proeminência no partido, que não cessaram até 1889, contribuíram para minar seu crescimento, mas também a atuação de sucessivos gabinetes liberais com caráter reformista, que incorporaram a discussão acerca do abolicionismo, temática implicitamente vetada nas fileiras republicanas.

3 O Clube Republicano, fundado em 1870, deu lugar ao Partido Republicano Federal em janeiro de 1875. 
Em 1887, foi realizado um congresso que reuniu os partidos republicanos de algumas províncias, empreendendo nova tentativa de organização do republicanismo, fundando-se um comitê executivo e uma assembleia constitucional. Ao contrário do esperado, a aparente desarmonia existente entre os segmentos republicanos não foi contornada, mas sim agravada a partir desse encontro, pois atingir o consenso entre eles não era mais possível à medida que vivenciavam realidades completamente diferentes, como os paulistas, que cresciam materialmente a passos largos, fortalecendo a ideia da autonomia provincial, ao contrário da decadência da economia nordestina, ancorada na produção do açúcar. A adoção do "federalismo partidário" acabava, enfim, por enfraquecer o movimento. Aliados a tal circunstância, dois fatores contribuíram para a divisão interna no partido republicano. O primeiro foi a presença gradativa do Exército nas reuniões de civis republicanos, o que demonstrava interesse em participar não só das críticas ao governo imperial, mas também do movimento republicano na imprensa e no ativismo político. Foi no congresso de 1887 que a chefia do partido passou a considerar o Exército como grupo fortalecedor do movimento e capaz de auxiliar no estabelecimento da República, tendo de deparar com a possibilidade de rever os meios para a mudança do regime, de forma lenta e gradual ou rápida, via mão armada (Lyra, 1964, p.134-8; Boehrer, s. d., p.193-8).

Após a Guerra do Paraguai, o clima de insatisfação no seio das Forças Armadas colocou os militares em uma posição suscetível de receber a influência de ideologias radicais, como o positivismo de Augusto Comte, por causa de sua insatisfação em relação ao governo imperial. Ao longo da década de 1880, a politização dos militares cresceu exponencialmente, passando a defender sua classe na imprensa e no campo político, aproximando-se de setores contestatórios, como o movimento abolicionista. Tais posturas renderam exonerações e transferências de militares pelo país, avolumando cada vez mais as críticas à Monarquia.

A consequência direta dessa posição e da radicalização política dos militares foi a fundação do Clube Militar, em 1887, sob liderança ideológica de Benjamin Constant, que defendia a implantação do 
positivismo por meio da discussão "calma e bem dirigida". Constant ministrava aulas na Escola Militar da Praia Vermelha desde a década de 1870 e havia tornado o local um reduto positivista na Corte. Em suas palestras, transmitia a necessidade de participação dos militares na política, despertando o sentimento contestatório na referida classe (Castro, 1995, p.66, 113).

Nesse período de debates internos do partido, veio à tona a divergência de opiniões entre Quintino Bocaiúva e Silva Jardim, republicanos atuantes, entusiasmados pelo alto número de adesões que o movimento vinha obtendo nos últimos anos. Bocaiúva defendia uma teoria evolucionista e democrática que se traduzia na transição gradual do regime monárquico para o republicano por meio de eleições e reformas no Estado. Essa teoria era predominante no grupo do Rio de Janeiro e de São Paulo, que não pretendiam ser identificados como agentes sediciosos. Como os próprios "evolucionistas" argumentavam, seria pela educação e pelo Parlamento que a República seria feita no Brasil. O contraponto ao evolucionismo era a corrente ditatorial ou revolucionária, veementemente defendida por Antônio Silva Jardim, que acreditava em um republicanismo baseado nas ideias de Auguste Comte, teoria relativamente aceita nos segmentos republicanos do Sul e do Nordeste do País. O conflito entre os dois republicanos logo tomou a cena política, e Bocaiúva e Jardim passaram dos laços de amizade ao total rompimento, denotando as disputas pela liderança do movimento e do partido em âmbito nacional (Costa, 1994, p.354; Boehrer, s. d., p.206-10, 233-9). Em maio de 1889, a questão foi resolvida sob inúmeros protestos: Quintino Bocaiúva foi indicado à chefia do partido, e a via pacífica ou eleitoral era adotada na propaganda republicana.

A trajetória do movimento republicano até 1889 apontava que, a despeito das lutas internas que serviram somente para enfraquecêlo, o federalismo constituía o grande laço que unia seus segmentos, a despeito das opções metodológicas por ele adotadas. Era a pedra de toque que pautava os discursos, os manifestos e as referências a outros países, como os Estados Unidos, que em sua história recente corroborava as ideias defendidas pelo grupo: o republicanismo democrático calcado no federalismo e na evolução política. 
O movimento não havia implantado a ideia da federação, pois era o argumento utilizado para justificar e defender a unidade imperial em contraposição à descentralização dos países de colonização espanhola. Antes de estar presente na fala dos republicanos, foi arvorada por segmentos liberais que viam problemas na administração imperial, prejudicada pela dificuldade de comunicação entre as províncias e um centro distante e ignorante perante as realidades regionais. Sua figuração nos discursos monarquistas estava associada ao temor frequente do separatismo, engendrando proposições reformistas de deputados liberais sobre a alteração da Constituição do país, tornando-o uma Monarquia federativa. Tal projeto, discutido no final da década de 1880, logo arrefeceu. Ouro Preto apresentou à Câmara dos Deputados um projeto que previa a ampliação da representação eleitoral e da cidadania, a autonomia das províncias e dos municípios, a liberdade de culto e ensino, a temporariedade do Senado e a elaboração de um Código Civil.

Às vésperas do 15 de novembro, as críticas dos militares ao Império, unidas ao descontentamento dos fazendeiros do oeste paulista e dos republicanos, se mostravam mais abertas do que os membros do campo político imperial, incapazes de se unir e de aplicar mudanças no edifício imperial (Costa, 1994, p.343-60). ${ }^{4}$ Esse fato se mostrava na luta entre os favoráveis à Monarquia federativa e os monarquistas defensores do status quo. Posteriormente à proclamação da República, em 1889, os primeiros foram derrotados, permanecendo o caráter conciliatório do campo político imperial.

Internamente, a análise dos dezenove anos que delimitaram o nascimento e a proclamação da República no Brasil autoriza dizer que as formas de pensar do movimento republicano estavam intimamente articuladas às suas formas de agir na sociedade. Ainda que a coerência entre sua forma de pensar e agir não fosse absoluta, eles utilizaram esse repertório comum para colocar na ordem do dia a discussão

4 José Murilo de Carvalho (1990, p.39) entende que os militares não tinham uma visão elaborada de República, buscando apenas maior prestígio e poder decorrentes da participação na guerra contra o Paraguai. 
sobre as relações e a disputa de poder no Brasil imperial, sobretudo por se verem excluídos da participação do poder. Dessa forma, esse conjunto de ideias e ações era eminentemente político, concebido e divulgado pela propaganda nos diversos jornais que surgiram nesse espaço de tempo (Alonso, 2002, p.36-45).

Durante esse período, foi primordial o contato desse grupo com ideias e teorias advindas do exterior. Em seus momentos iniciais, o republicanismo já se esboçava a partir de três vertentes ou referenciais, as quais cada grupo defendia como legítimas e que, após o golpe de 15 de novembro, foram aglutinadas e sintetizadas na republicanização do regime. Dizia-se que os indivíduos (ligados ao movimento de 1870) eram republicanos por causa de Comte e do positivismo, da França e, por fim, dos Estados Unidos.

O exemplo mais conhecido, o positivismo comtiano, foi gradativamente incorporado pelos oficiais de patentes inferiores brasileiros, alunos da Escola Militar, alterando seu comportamento de modo a defender a hipótese de que a participação militar no campo político seria mais eficaz do que a civil, corrupta e desconhecedora dos interesses nacionais (Costa, 1994, p.332). Para José Murilo de Carvalho (1990, p.136-8), o positivismo à brasileira propunha certo "bolchevismo de classe média”, isto é, um voluntarismo político que acreditava poder forçar a marcha da história pela ação de uma vanguarda política bem organizada e homogênea. Não somente como berço das ideias positivistas, a França, em 1870, iniciava o período conhecido como "Terceira República”, que acabava de conter o movimento de restauração monárquica e significou alto fortalecimento do grupo republicano do país. Na prática, o paradigma francês de República foi relegado a um segundo plano pelos republicanos brasileiros, que se polarizaram efetivamente nas referências positivistas e ao continente americano, posicionamento este que estava presente no Manifesto do Clube em dezembro de 1870 (Lyra, 1964, p.52).

Somos da América e queremos ser americanos. A nossa forma de governo é, em sua essência e sua prática, antinômica e hostil ao direito e aos interesses dos Estados americanos. A permanência dessa forma tem 
de ser forçosamente, além da origem de opressão no interior, a fonte perpétua da hostilidade e das guerras com os povos que nos rodeiam. Perante a Europa passamos por ser uma democracia monárquica que não inspira simpatia nem provoca adesão. Perante a América passamos por ser uma democracia monarquizada, aonde o instinto e a força do povo não podem preponderar ante o arbítrio e a onipotência do soberano. Em tais condições pode o Brasil considerar-se um país isolado, não só no seio da América, mas no seio do mundo (Pessoa, 1973, p.39-62).

A referência ao continente americano era, para esse segmento republicano, a condição primordial do estabelecimento do federalismo, para eles bem aplicado no caso norte-americano, que se aproximava do Brasil por causa de sua geografia e, guardadas certas proporções, sua história. Para além dessa questão, a presença de uma Monarquia na América era encarada pelos demais países, especialmente os de origem hispânica, como uma séria ameaça à sua soberania, posição que dificultava a aproximação e cooperação entre os países (Azêdo, 1975, p.74-5). Ao fim, a América propagava um modelo político a ser seguido: o regime republicano, cujo exemplo maior eram os Estados Unidos. Tal como o país da América do Norte, a forma de governo do Brasil deveria ser apropriada às suas dimensões territoriais e à sua composição populacional, tornando o conceito de republicanismo cada vez mais próximo da conotação de americanismo. Essa associação entre a perspectiva política com a geográfica ganhava força porque era justamente o argumento rebatido pelos agentes da política exterior do Império que procuravam estabelecer padrões baseados na cultura política europeia, em grande medida conectada ao monarquismo (Magnoli, 1997, p.205).

A política externa do Império possuía princípios gerais que nortearam suas ações durante a segunda metade do século XIX e estavam articulados com o papel econômico que o Brasil exercia no contexto regional e mundial (Bueno, 1995, p.22). O crescimento da produção e exportação de café foi um fator essencial na desestabilização da política monárquica, que não soube se adaptar às transformações decorrentes da complexificação da economia internacional. 
O primeiro princípio baseava-se no controle da política alfandegária e comercial do País, consequência imediata dos diversos acordos efetuados com a Inglaterra, França e países europeus, de onde provinham altas rendas para o Brasil, portanto um local de grande interesse estratégico.

O segundo princípio não foi permanente, mas desenvolvido de acordo com as circunstâncias: o estímulo à imigração, prática intensificada com a abolição do tráfico de escravos em 1850 e o movimento abolicionista na década de 1880, processos que indiretamente auxiliaram a circulação e a discussão de novas ideias acerca da mão de obra empregada nas lavouras de café, notadamente na província de São Paulo, de onde saíram republicanos que se destacaram nacionalmente, como Prudente de Morais e Campos Sales.

O terceiro princípio pode ser nomeado de política de limites, na qual o país procurou agressivamente consolidar seu território. Esse conjunto de ações, espalhado ao longo do século XIX, agravou-se no Segundo Reinado, gerando conflitos com Uruguai (1851 e 1864), Argentina (1852) e Paraguai (1865-1870). A unidade territorial do país foi um traço fundamental da imagem do Império e intensificada após a dissolução da hipoteca diplomática representada pelo tráfico negreiro. A delimitação do território estava ligada a duas condições essenciais para a construção da nação brasileira: a tradição, ou seja, a pátria no tempo, e o território, a pátria no espaço. Assim, o Império buscava na união da história com a geografia (por meio de sua política externa) a definição da nação e da nacionalidade.

O último desses princípios era a pretensão de hegemonia regional, sustentáculo das ações brasileiras no enfrentamento político, econômico e cultural com seus vizinhos sul-americanos. As intervenções na Cisplatina e a guerra com o Paraguai afiliavam-se a tal tendência, vista como ameaça pelos países vizinhos à medida que uma casa dinástica com origem europeia as comandava, o que literalmente significava a presença do fantasma repelido durante o processo de independência (Magnoli, 1997, p.110, 125).

Na manutenção desse conjunto de práticas da política externa, o Império do Brasil enfrentou pressões de ordens diversas, como a 
contenda acerca da livre navegação de embarcações de outros países em rios brasileiros como o Amazonas e o São Francisco. Com o intuito de preservar o suposto "legado colonial", a Monarquia adotava uma postura rígida no que tangia à exploração estrangeira do País, desejando ser exclusiva na navegação nos rios que tinham acesso ao interior do País. Manteve tal postura até 1866, quando cedeu às influências externas, permitindo a navegação e o acesso estrangeiros nos rios mais importantes. À época, especulava-se que os temores brasileiros apoiavam-se em um suposto plano de colonização da região amazônica, encabeçado pelos Estados Unidos, que traria aventureiros com o fito de conquistar territórios e a simpatia da população local, semelhante ao ocorrido no território do Texas, antes território mexicano, incorporado à União norte-americana em 1845. Ainda que tal plano não fosse concreto, havia interesse real e estratégico pela importância econômica que a região amazônica adquiria por meio da extração da borracha. Contudo, no ano de abertura dos rios pela Monarquia brasileira, os norte-americanos pouco podiam fazer na região, pois ainda sentiam os efeitos devastadores da guerra civil que terminara em 1865 e que havia destruído cidades inteiras e matado quase setecentas mil pessoas (Bandeira, 1973, p.87-97).

A confluência dos interesses norte-americanos com os brasileiros sofria com a falta de diálogo efetivo, por meio da diplomacia ou do comércio. As divergências existiram durante alguns momentos, como a guerra civil, na qual o Império brasileiro tendeu a apoiar os confederados, escravistas e defensores da produção agrícola, um quadro econômico e social que se aproximava do Brasil e o ligava aos Estados Unidos, ao contrário dos unionistas, voltados essencialmente para a industrialização. A diplomacia norte-americana acusava o Brasil de romper a neutralidade, ao ponto de o secretário de Estado norte-americano William Seward e o general Watson Webb, ambos unionistas, negarem ao Brasil o direito de reconhecer como beligerantes os confederados, seus adversários (Bandeira, 1973, p.100-1; Eisenberg, 1999, p.65-7). A retaliação diplomática viria logo em seguida, por ocasião da Guerra do Paraguai, quando o representante norte-americano naquele país se colocou à disposição das forças de 
Solano López em nome de seu país, levando Caxias, comandante das forças brasileiras, a impedir a saída e a entrada de norte-americanos por meio do contingente militar brasileiro, terminando com a suspensão das relações entre os dois países (Bandeira, 1973, p.105-14).

Os anos subsequentes à guerra civil foram de intensa modernização e incremento da economia norte-americana, ao mesmo tempo que os Estados Unidos iniciavam a revitalização de sua política exterior, comprometida com o desejo de aumentar sua presença física (por meio de seus produtos industrializados) e ideológica no exterior. Desse comprometimento surgia uma nova leitura da declaração de James Monroe, em 1823, que ficara conhecida como Doutrina Monroe.

Originalmente declarava que os Estados Unidos não admitiriam nenhuma intervenção na América, seja para a criação de colônias, seja para a resolução de conflitos domésticos, o que, ao fim, era a manifestação contra os interesses europeus no continente, em um momento de estruturação e organização do País. A declaração possuía muito mais uma carga ideológica e moralista do que uma demonstração de força militar no cenário internacional, apesar de os norte-americanos se encontrarem à frente da economia e da sociedade das ex-colônias hispânicas recém-independentes. A fragilidade dos Estados Unidos por volta de 1823 limitava o alcance do discurso do presidente Monroe à porção da América do Norte, sem as claras pretensões de conquista que surgiram nas décadas seguintes. Curiosamente, a GrãBretanha foi beneficiada com a declaração, pois minou os interesses de outros países europeus no continente e conseguiu manter seus privilégios (Magnoli, 1997, p.188). A revisão da Doutrina utilizou o conteúdo do discurso, porém adaptou-o às circunstâncias internacionais, completamente distintas de 1865 em diante.

Assim, foi constantemente trabalhada pelos políticos norte-americanos como uma ideologia de segurança nacional, servindo para a manutenção e a expansão territorial e também como fundamento da política do país para a América Latina, determinando sua ação na região. As ações monroístas se multiplicaram no final do século XIX, sendo efetivadas nas regiões do Caribe, como em Cuba (em 1869 e 1877), e a anexação da República Dominicana, vetada 
pelo Senado norte-americano também na década de 1870, sendo considerada "a mais importante ação de política externa norte-americana no século XIX, constituindo uma vigorosa afirmação de seus interesses" (Schoults, 2000, p.5-13; Pecequilo, 2003, p.67).

A visão de mundo norte-americana sobre a América Latina era negativa: via-se a herança social, cultural e política dos ibéricos na América como uma síntese dotada de inferioridade e ignorância, ao contrário de seu progresso e desenvolvimento autônomos, afinal era talhada pela imprensa do País e na política interna, repercutindo nas ações de política externa (Schoults, 2000, p.111). Ao mesmo tempo, desejava-se a estabilidade da região para que as interferências não norte-americanas fossem anuladas. A Doutrina Monroe revista era complementada pelo Destino Manifesto, expressão frequentemente utilizada pelos mesmos segmentos de opinião - oficial e público - para designar que o povo norte-americano era eleito por Deus, o que justificaria o intervencionismo em outros territórios e a posterior conquista. Nas décadas de 1830 e 1840, ele foi bastante utilizado na conquista do Texas, posteriormente Estado da União norte-americana. Décadas mais tarde, seu emprego foi desaparecendo nos discursos e em jornais, mas não deixou de ser praticado. Em síntese, os norte-americanos chegavam à década de 1880 sustentando uma política externa firmada na predestinação geográfica e no direito divino, sendo temidos pelas repúblicas latino-americanas e impelidos para o exterior graças ao crescimento de sua produção interna.

A simples contraposição da trajetória do Brasil e dos Estados Unidos no século XIX evidencia o quão contrastantes eram suas sociedades, para além da constatação óbvia da diferença do regime político adotado. A visão de mundo dos brasileiros em relação aos norte-americanos era definida pela desconfiança e, do lado norte-americano, tratada como uma relação de superioridade/inferioridade. $\mathrm{O}$ ponto comum entre as visões desses países era o crescente interesse em ampliar suas áreas de influência na América: o Brasil no âmbito regional, e os Estados Unidos no âmbito continental. Contudo, mesmo que as ações de política externa fossem essencialmente distintas uma da outra, existiam relações entre os 
países que tendiam ao crescimento. Na década de 1870, o Brasil produzia 49,09\% da produção mundial de café, e os Estados Unidos já eram o maior comprador do produto, o que conferia à esfera de atuação situada entre os interesses internacionais de cada país - a diplomacia - um elevado grau de importância (Pinto, 1984, p.139).

No caso brasileiro, esse processo se tornava representativo, caso se notasse o desequilíbrio entre o campo político e o econômico, ou o período de demandas por reformas estruturais no Estado, do qual surgiu o grupo republicano que se espalhou com relativa rapidez pelas províncias, ainda que permanecesse um grupo minoritário.

A ligação do movimento republicano com a política exterior do Brasil foi exposta no Manifesto Republicano em 1870, que entendia ser a Monarquia incompatível com o espaço ocupado pelo Brasil. Em um continente inteiramente republicano, o País era uma fonte de hostilidade permanente aos seus vizinhos, ciosos de seus territórios ante um Brasil conquistador. Ao mesmo tempo, os partidários da Monarquia atacavam a República norte-americana - o paradigma político utilizado pelos republicanos brasileiros - como a fonte de instabilidade no continente, servindo-se dos conflitos estimulados por ela e suas conquistas subjacentes.

A desarmonia entre o crescimento da economia e a necessidade de transformações políticas evocada pelos republicanos chegou até à diplomacia no mesmo período de seu surgimento. A trajetória de Salvador de Mendonça, analisada à luz de tais considerações, insere-se de forma representativa no período de enfraquecimento do edifício imperial, permeado de contradições e oportunismo político.

Salvador de Menezes Drummond Furtado de Medonça nasceu em Itaboraí, na província do Rio de Janeiro, em 1841. Depois de iniciar seus estudos na Corte, foi para São Paulo, em 1859, iniciar o tradicional curso de Direito, tendo por colegas de turma Prudente de Morais, Campo Sales e Américo Brasiliense. Na faculdade, o clima reformista na ordem do dia levou-o a se unir aos liberais radicais na escrita de textos que criticavam o predomínio conservador e a Monarquia. No mesmo ano, escreveu no folheto A legenda, sobre o campo político: 
Liberais em extremo, mas sustentadores ainda do sistema monárquico constituicional representativo, havemos de mostrar os vexames e as privações que sofre o povo, enquanto os cortesãos e os parasitas se atropelam junto ao trono fazendo luzir os seus galões de ouro nas librés que servem nos dias de mascaradas nacionais. Escrevemos para brasileiros: eles nos hão de ouvir (Mendonça apud Azevedo, 1971, p.38).

O discurso em tom de conciliação, comum no campo político imperial, alterou-se significativamente em 1869, ano em que Salvador de Mendonça formou-se em Direito. ${ }^{5}$ As dificuldades financeiras, agravadas pela morte dos pais, e a orfandade de numerosa família obrigaram-no a estender o tempo de seu curso e voltar ao Rio de Janeiro, fato que contribuiu para sua aproximação com a imprensa e a literatura. $\mathrm{Na}$ década em que se formava, selou laços de amizade com Saldanha Marinho, diretor do Diário do Rio de Janeiro, e passou a colaborar com o periódico, escrevendo artigos a fim de custear as despesas da família. Na correspondência entre Salvador de Mendonça e Marinho, observa-se que aquele considerava esse político liberal seu "padrinho político", cuidando para que se atentasse à crise que atravessava a política brasileira. Nesse ínterim, substituiu Joaquim Manuel de Macedo (que o havia indicado), para ministrar aulas de História do Brasil no prestigiado Colégio Pedro II, na Corte. Entre os melhores alunos, estavam Joaquim Nabuco e Rodrigues Alves, "grandes promessas" conforme observação de Salvador (Azevedo, 1971, p.50, 445-55).

Salvador de Mendonça retornou definitivamente à Corte entre 1869 e 1870, objetivando ater-se à profissão e ao jornalismo. Em meio ao clima contestatório dos liberais radicais, entre eles Saldanha Marinho e Cristiano Ottoni, juntou-se ao grupo, o qual organizava a fundação do Clube Republicano; este teria órgão de imprensa próprio, local em que poderia colaborar efetivamente e colocar em prática as ideias com as quais teve contato em São Paulo. Nas reuniões que

$5 \mathrm{Na}$ Academia Brasileira de Letras, pasta 2, encontra-se um exemplar manuscrito do jornal O Ypiranga, editado por Salvador de Mendonça e Ferreira de Menezes em 1869. As críticas ao poder "pessoal" do imperador estão disseminadas por todo o jornal, além de referências ao regime político norte-americano. 
antecederam a fundação do Clube, foi eleita a comissão que elaboraria o programa do futuro Partido Republicano. Compunham-na Salvador de Mendonça, Quintino Bocaiúva e Saldanha Marinho. Foi desse grupo que saiu redigido o Manifesto, publicado na primeira edição do jornal A República, órgão do Clube Republicano e escrito a quatro mãos: a autoria fora dele e de Bocaiúva (Mendonça, 1960, p.69-71).

Os anos sequentes ao periódico foram determinantes para a carreira jornalística de Salvador de Mendonça como propagandista republicano. A República havia aumentado o número de exemplares em circulação e sobrevivia com a renda de assinaturas e publicidade dos integrantes do Clube, apesar de ser em grande medida custeada por Luis Barbosa da Silva, que vinha dos Estados Unidos animado pela ideia republicana. Com a saída de Barbosa da Silva, em 1872, em razão das disputas pela direção e sobre o formato das publicações do jornal, resolveram se retirar também Salvador e Quintino Bocaiúva, expondo os primeiros sintomas de uma crise no grupo do Rio de Janeiro.

No ano seguinte, uma comemoração realizada na sede do Clube em prol da proclamação da República na Espanha ocasionou a intervenção da polícia e a interrupção da publicação, que se arrastou até fevereiro de 1874, quando deixou de existir definitivamente (Mendonça, 1960, p.79-82; Azêdo, 1975, p.35-6). Com o fim da folha, Salvador de Mendonça passou a se dedicar à literatura, relacionando-se com Machado de Assis e José de Alencar, que prefaciou seu primeiro e único romance, intitulado Marabá: romance brasileiro, publicado em 1875. A obra, apesar do conteúdo romântico, continha implicitamente os elementos da plataforma republicana de sua época, apostando no elogio ao sistema federalista, e o entusiasmo pelos Estados Unidos. ${ }^{6} \mathrm{O}$ diálogo entre dois personagens da obra descrevia as características dos indivíduos de alguns países - França, Inglaterra e Estados Unidos - narrando que os franceses, apesar de se esforçarem pela emancipação dos povos, não o fizeram a si próprios, e os ingleses

6 O romance é a história de uma família aristocrática falida no interior de São Paulo que pretendia obter a recuperação financeira com o casamento da filha, que havia ido estudar na Corte. A solução dada por Salvador de Mendonça é a chegada de um antigo morador da fazenda da família que viajou o mundo e ficou rico nos Estados Unidos, trazendo a referência ao self-made-man. 
tinham uma aristocracia anacrônica ao mesmo tempo que sabiam conquistar e manter suas liberdades. Quanto ao norte-americano,

- Nenhuma liberdade lhe falta. Está de posse quanto é necessário para a expansão de sua atividade prodigiosa. Mas por quê? Porque não há, talvez, no mundo, cidadão que melhor o saiba ser. A instrução pública não tem mais severo fiscal, nem mais dedicado contribuinte. Escolhe o seu talante o seu culto e possui fé convicta. [...] Respeita as leis e as autoridades constituídas, porque as fez e as constituiu, e não tem escrúpulo em reformá-las ou substituí-las, quando são ou se tornam más.

- É o que também devemos fazer aqui, porque leis e autoridades não podem ser piores, acudiu José Alves, que até aí ouvira atento seu interlocutor. [...]

- Mudem-se as instituições! Disse José Alves, com calor. (Mendonça, 1875, p.87-91)

Adiante, as falas dos personagens possuem forte relação com o mundo político:

- Olhem: os Estados Unidos dão lições ao mundo nestes assuntos. Quem observa, de fora, aquela poderosa nação, supõe que o princípio descentralizador proferiu a sua última palavra: é um erro. A Grande União possui a descentralização administrativa, possui descentralização política, mas só em parte possui a descentralização econômica, e essa pequena falha da armadura democrática pode trazer-lhe ainda grave perigo, nada menos que o enfraquecimento da liberdade de expansão na política e na administração. [...] Felizmente começamos com a lição da experiência. Mas os que assim começam não podem ser republicanos à francesa ou à espanhola; devem ser antes de tudo, republicanos práticos, Sr. José Alves. Demasiada liberdade temos nós para sê-lo: o que não temos ainda é toda a força de iniciativa que a empresa requer (ibidem).

Salvador de Mendonça não havia se afastado por completo da propaganda republicana. Desde que saíra de A República, que se 
encontrava em crise, Quintino Bocaiúva estabelecera outro periódico nomeado $O$ Globo, folha para qual colaborou entre 1874 e 1875, encarregando-se das matérias sobre a Câmara dos Deputados, até ser convidado por José Carlos Rodrigues a escrever para o Novo Mundo, periódico brasileiro com correspondentes no exterior. Comunicou o convite ao amigo João Cardoso de Meneses e Sousa, poeta, jornalista e político imperial. ${ }^{7}$ As relações entre os dois era o sinal de que havia certo cavalheirismo entre republicanos e monarquistas tanto quanto entre liberais e conservadores: Lúcio de Mendonça contava que a sala de editoração do órgão de imprensa republicana no Rio de Janeiro era frequentada não somente por seus membros, mas também por Joaquim Nabuco, Machado de Assis e Francisco Otaviano, que, na década de 1870, já era senador do Império.

De outra perspectiva, os republicanos dependiam dessa relação amistosa para com o campo político, oficial para a manutenção da via evolutiva do processo de mudança do regime, que ainda se firmava nas ideias do grupo. A existência aberta de tais relações não passava despercebida pelos segmentos conservadores que estavam no poder em um momento de entusiasmo republicano, por mais que o crescimento da propaganda e do número de adeptos fosse fragmentado pelas províncias. A reação frente perante situação foi dupla: a violência ou o aliciamento. E, nesse sentido, os irmãos Mendonça sentiram as duas práticas: Lúcio foi suspenso da Faculdade de Direito em São Paulo por ter participado de protestos a favor da República, e Salvador foi convidado a ser cônsul do Império do Brasil em Baltimore, nos Estados Unidos (Alonso, 2002, p.110).

A estratégia imperial de cooptação era geralmente bem-sucedida e não vista com descontentamento pelos republicanos. Conforme narrativa de Salvador de Mendonça (apud Azevedo, 1971, p.50-1):

Procurei um por um dos companheiros do primeiro Diretório Republicano: Saldanha Marinho, Quintino Bocaiúva, Lafayette e

7 João Cardoso de Meneses e Sousa foi deputado pela província de Goiás entre 1873 e 1876 e, posteriormente, nomeado barão de Paranapiacaba, em 1883. 
Aristides Lobo; a este não encontrei por ausente na cidade; os três consultados responderam-me uniformemente que, no regime que vigorava os cargos administrativos não pertenciam ao Imperador, mas ao Gabinete responsável; que os republicanos não podiam ser deles excluídos; que não era sequer lugar de confiança política o que me fora oferecido e que conseguintemente não haveria quebra nem derrogação do credo republicano em aceitá-lo. Aceitei-o e fui nomeado para o Consulado de Baltimore até que houvesse vaga no de New York.

O movimento republicano iniciava seu período de letargia e via seu contingente esvaziar, especificamente na Corte, onde era composto por forças individuais, ao contrário de São Paulo ou no sul do país, que tinha força coletiva e trabalhava de forma consensual. $\mathrm{O}$ golpe mais duro foi dado por Lafaiete Rodrigues Pereira, que havia assinado o Manifesto do Clube em 1870 e aceitava integrar o gabinete liberal de 1878, chefiado pelo visconde de Sinimbu (Lyra, 1964, p.125). Salvador, por sua vez, insistiu que ia aos Estados Unidos tão republicano quanto o era antes, mas não negava os elogios ao amigo Paranapiacaba, que lhe conseguiu a indicação e a tolerância do imperador que aprovara sua nomeação. Ao partir, recomendou ao irmão Lúcio de Mendonça que professasse a fé republicana com moderação, o que não seria obstáculo algum para que todo brasileiro em que os adversários reconhecessem algum mérito prestasse serviços ao País (Mendonça apud Azevedo, 1971, p.103-4). ${ }^{8}$

Sua nomeação foi feita em 23 de junho de 1875, como cônsul privativo do Império do Brasil em Baltimore, Estados Unidos. ${ }^{9}$ Ao

8 José Afonso Azevedo (1971, p.50) defende a hipótese de que o barão de Paranapiacaba foi o "padrinho" de Salvador de Mendonça. Na ocasião de seu ingresso na diplomacia, argumenta que, por intermédio do visconde do Rio Branco, à revelia de Mendonça, obteve sua nomeação para cônsul em Baltimore.

9 Durante o Império, o Ministério de Negócios Estrangeiros não previa uma carreira diplomática organizada, como durante a República se estabeleceu. Os cargos se davam por nomeação, e havia três classes de agentes diplomáticos (em ordem crescente de importância): a) os secretários e adidos de legação, b) ministros residentes e encarregados de negócios, e c) enviados extraordinários e ministros plenipotenciários (Castro, 1983, p.144). 
se apresentar para receber as credenciais em Nova York, recebeu a notícia do falecimento do cônsul-geral do país naquela cidade, sendo nomeado para exercer o cargo desocupado de forma interina até ser nomeado oficialmente, o que ocorreu em outubro do mesmo ano. Os primeiros relatos sobre a estrutura do consulado brasileiro eram negativos, parecendo haver certo descaso para com tão importante representação diplomática. Importante não só porque Mendonça nutria simpatias políticas para com os Estados Unidos, mas porque o País viria a ser o maior comprador do café brasileiro.

Os Estados Unidos já são o maior consumidor do nosso primeiro produto agrícola, assim como nos fornecem quase exclusivamente um dos gêneros de importação de primeira necessidade para nós. Estas relações comerciais, já muito dignas de atenção, podem ser consideravelmente melhoradas, desde que se lhes ligue o interesse que estão reclamando. Outros produtos nossos além do café podem ser exportados para estes Estados, donde poderemos também receber vários gêneros que ainda importamos da Europa por serem aqui bem pouco conhecidos dos nossos mercados. [...] Além destes assuntos, outro de não menor importância e que lhes é conexo pede acurado zelo: refiro-me à imigração. Raro não é o dia em que se não apresentem neste Consulado indivíduos que desejam seguir para o Brasil (Mendonça apud Azevedo, 1971, p.124).

Próximos comercialmente do Brasil, os Estados Unidos completariam o centenário de sua independência no ano seguinte, 1876, organizando na Filadélfia a Exposição Universal, que pela primeira vez seria realizada fora do continente europeu, o que poderia, por meio da participação brasileira no evento, incrementar o número de exportadores de produtos brasileiros. O Império atentou-se para a ocasião, e D. Pedro II resolveu ir até os Estados Unidos, causando impressão positiva perante os norte-americanos, que o admiraram pela discrição com que percorria as cidades do País, segundo relatos do diplomata brasileiro. Salvador de Mendonça (1913, p.100-1) tratou com ironia a visita comparada à importância da diplomacia 
brasileira naquele país, julgando que, após a visita do imperador, as relações comerciais entre os dois países melhoraram, "tudo isso, porém, não era devido à nossa importância diplomática, sinão [sic] ao valor pessoal do velho Imperador". Para Oliveira Lima (1927, p.210), havia um aspecto importante a considerar na imagem que o imperador possuía: ele representava, como um cônsul do País, a transição do referencial de política externa brasileira da Inglaterra para os Estados Unidos.

De começo o Império tinha contado muito com a simpatia britânica porque a cisão do Reino Unido favorecia os interesses comerciais ingleses e da Inglaterra se importou o constitucionalismo como sistema de governo; mas a tendência de aproximação política foi mais profunda para o lado da América do Norte. Das repúblicas neo-espanholas distanciavam o Brasil antipatias peninsulares herdadas e transplantadas e prevenções filiadas na sua natureza imperial que parecia prenunciar absorções e emulações [...] as duas grandes uniões do Novo Mundo, a americana e a brasileira, entenderam-se sempre perfeitamente e não melhor agente dessa "entente cordiale" do que D. Pedro II (Magnoli, 1997, p.204).

Até o fim da década, Salvador de Mendonça se dedicou a inspecionar e requisitar modificações nos consulados e nas agências comerciais brasileiras nos Estados Unidos com vistas a aperfeiçoar o contato com as instituições e produtos norte-americanos, procurando não se afastar do jornalismo nos elogios impressos nos artigos que enviava aos jornais $O$ Cruzeiro, entre 1878 e 1883, e ao Diário da Bahia, de 1880 a $1881 .{ }^{10}$ Mesmo longe do Brasil, Salvador de Mendonça não deixava de receber informações acerca das lutas políticas no Império. Em carta ao representante brasileiro, Francisco Otaviano Rosa, senador, contava sobre o certame liberal-conservador em 1878:

10 A correspondência de O Cruzeiro foi compilada por Salvador de Mendonça sob o título Cartas americanas, já os artigos do Diário da Bahia tornaram-se Cartas dos Estados Unidos (Azevedo, 1971, p.331-46). 
[...] meu Salvador, não nos iludamos! Se os liberais não puderem fazer o bem, agora depois de nove anos de balbúrdia conservadora, se eles caírem para substituir os conservadores, o país entra em convulsão: a luta não será mais entre liberais e conservadores, será entre republicanos e monarquistas; ou os republicanos se prepararão com talento para serem os fortes, e então a monarquia ruirá; ou, os ambiciosos precipitam as coisas, e os monarquistas vencem, atrasando por muitos anos, o progresso desta nossa pátria. E ouve aqui no teu ouvido, meu republicano da Ma . Escola; se acaso houver luta armada e os monarquistas vencerem, a única garantia de moderação será o Imperador! Nesse caso é pedir por sua vida (Rosa apud Azevedo, 1971, p.409).

Para os integrantes do campo político oficial, o gabinete liberal era a grande esperança de comandar as reformas na Constituição do país, ao mesmo tempo que o movimento republicano recrudescia pela proximidade de alguns pontos defendidos pelos dois grupos, a disputa interna, e pela evasão de seus membros.

Em 1880, foi criada a Sociedade Brasileira contra a Escravidão, por Joaquim Nabuco e José do Patrocínio, ativando o debate sobre o abolicionismo, com o qual o Estado já era abalado. Atentando-se para a questão, o governo brasileiro requisitou uma série de estudos sobre alternativas de imigração de trabalhadores. Na prática, Salvador de Mendonça (1879) escreveu nos Estados Unidos uma série de estudos acerca da imigração chinesa e norte-americana, que guardava uma dupla "solução": os orientais seriam direcionados à agricultura, e os norte-americanos, à colonização do norte do País (Alonso, 2002, p.112).

Foi dada, então, prioridade ao conhecimento e às possibilidades da imigração chinesa, que poderiam servir como alternativa ao trabalho escravo. Em documento enviado em 28 de abril de 1879, Mendonça se preocupou em descrever a história geral da China e os acordos firmados com outros países com a mesma finalidade: levar trabalhadores para suas lavouras portando novas técnicas de produção e maior produtividade. 
Os Estados Unidos haviam consolidado o processo desde a segunda metade do século XIX, e a presença oriental no País diversificou não somente a produção agrícola, mas o mundo urbano, trazendo novos conceitos arquitetônicos e de organização social, o que, em contrapartida, fazia amainar o preconceito contra eles. Salvador de Mendonça não via dificuldades na adaptação dos chineses no Brasil, pois seu país de origem era semelhante em relação às terras e, em parte, ao clima, o que facilitaria a produção de café e de outros produtos agrícolas. O diplomata brasileiro também atribuía, em seu estudo, algumas características psicológicas e físicas dos prováveis imigrantes quanto à capacidade e disposição ao trabalho, a inteligência e inclinação ao descumprimento da lei, indicando a imigração oriunda da região do Cantão como a geradora dos chineses mais adaptados ao trabalho requerido pelo Império brasileiro.

À frente, discutia como seria feito o transporte dos imigrantes, ressaltando que viviam apenas com a quinta parte do que empregava um trabalhador europeu, barateando o custo dos produtos para os produtores. Por fim, julgava que caso o Brasil se interessasse pela questão, o primeiro passo seria abrir consulados na região e aderir ao acordo sobre imigração de 1866, assinado por países europeus e pelos Estados Unidos (Mendonça apud Azevedo, 1971, p.361-79).

No mesmo período, no continente sul-americano, pendências acerca do controle sobre recursos naturais entre o Chile, o Peru e a Bolívia, sendo os dois últimos aliados, iniciaram-se com uma querela comercial, mas acabaram em um conflito armado conhecido como Guerra do Pacífico, que aconteceu entre os anos de 1879 e 1881. Os norte-americanos tentaram, em 1880, fazer a mediação do conflito por meio da diplomacia, mas não obtiveram sucesso, tendo a guerra terminado com Bolívia e Peru derrotados pelo Exército chileno, que anexou a saída boliviana para o mar. O mal-estar diplomático causado no continente perdurou até o fim da década de 1880, quando se realizou em Washington a I Conferência Internacional Americana, prevista inicialmente para acontecer em 1882, porém adiada em razão pelo conflito. 


\section{A Conferência de Washington e o reconhecimento da República}

Nas décadas finais do século XIX, os políticos norte-americanos haviam chegado à conclusão que, se desejavam enfrentar o problema das crises em sua economia saturada pelo excesso de produtos que não encontravam consumo no mercado interno, o problema deveria ser direcionado pelo aumento das exportações, ainda que tivessem que tomar clientes da Grã-Bretanha (Schoults, 2000, p.108). Portanto, promover um encontro com os países americanos seria um momento oportuno para discutir os escassos acordos comerciais e de cooperação existentes entre eles, a despeito da proximidade geográfica.

Em 24 de maio de 1888, pouco tempo depois da assinatura da Lei Áurea, o Brasil era convidado pelos Estados Unidos, bem como os demais países da América, para participar da Conferência Internacional Americana, a realizar-se no fim do ano de 1889 e início de 1890. No documento que promovia o encontro, oito pontos eram propostos para a discussão, englobando: medidas que visassem conservar a paz e a prosperidade entre os Estados americanos; medidas tendentes à formação de uma união aduaneira americana, base de fomento do comércio entre as nações, ponto do qual se desdobravam outros concernentes à união das tarifas alfandegárias, pesos e medidas adotados, e uma moeda comum a ser usada nas transações comerciais. O sétimo ponto referia-se à confecção de um plano definitivo de arbitragem para todas as questões que suscitassem a discórdia entre os Estados presentes para que a guerra fosse evitada, buscando sempre a solução pacífica (Azevedo, 1971, p.186-9).

O gabinete do Império (que se encontrava em transição dos conservadores para os liberais), em relação ao recebimento do convite, não era uma novidade: repetiu-se a postura de hesitação, justificada pela diferença do regime político, que delineava todas as conferências anteriores (Santos, 2004, p.31-2).

A história das conferências interamericanas esteve, de uma forma ou de outra, articulada com a construção social, econômica e cultural de cada região do continente, remontando ao período colonial e ao 
contraste entre os diferentes processos de colonização e os rumos tomados pelas sociedades que se desenvolveram, dadas as influências espanhola, anglo-saxã e portuguesa, que determinaram sua aproximação ou o seu distanciamento. Enquanto a América espanhola foi marcada pela fragmentação territorial e pelo fortalecimento das elites regionais, no norte do continente, a postura pragmática dos anglo-saxões engendrou a racionalização da política e o fortalecimento do regime republicano, ao contrário da instabilidade dos hispânicos, marcados pela instabilidade política ocasionada pelas lutas por predominância política e econômica na região.

Ao sul do continente americano, a colonização portuguesa produziu um fruto distinto dos casos anteriormente mencionados, na medida em que o pacto entre segmentos de elite no processo de independência garantiu a manutenção do regime monárquico e solidificou o paradigma europeu de civilização. ${ }^{11} \mathrm{O}$ Brasil independente passou, então, a mirar na Europa as referências de sua sociedade política, porém conservando o traço arcaico do trabalho escravo.

Se, para nossos vizinhos americanos o "outro" era a Europa e o Antigo Regime; para o Império esse "outro” era justamente o conjunto das repúblicas americanas. O Império construiu sua auto-imagem a partir da concepção de superioridade da civilização que seu regime político representava, ao aproximá-lo das monarquias europeias. Ainda que escravista, atrasado e distante, o Império via-se como distinto e superior a seus vizinhos, os quais entendia como anárquicos e instáveis (Santos, 2004, 134-5).

Unidas ao redor de traços culturais comuns oriundos da conquista europeia, as ex-colônias espanholas promoveram diversas

11 Apesar de Santos (2004) não conceituar "civilização", sua intenção incide no significado moral que o termo adquiriu na França iluminista do século XVIII: ser civilizado era ser bom, culto e educado, em contraposição à ideia de barbárie e selvageria. Este é, segundo Kalina Silva (2006, p.59-62), seu significado mais constante na história ocidental. Em um sentido contemporâneo, ser civilizado acabou por significar superioridade cultural. 
tentativas de integração com o fito de se fortalecer contra agressões externas e assim assegurar sua independência. A primeira dessas iniciativas ficou a cargo de Simón Bolívar (1783-1830), que convocou representantes dos países americanos de origem hispânica para participar de um evento coletivo em 1826, sem muito sucesso. No Congresso do Panamá, como ficou conhecido o encontro, a escassa participação dos novos países dissolveu a ideia de Bolívar, retomada anos mais tarde, mas sem sua presença (Santos, 2004, p.78-80; Souto Maior, 1993, p.332-3). Paralelamente ao evento, era disseminada a declaração em 1823 do presidente norte-americano que se tornou anos mais tarde a Doutrina Monroe, delineando o discurso deste país que, a seu modo, procurava livrar-se das arbitrariedades europeias. Ainda que o discurso estivesse circunscrito ao território norte-americano, logo se espalhou pelo continente, interpretado como proteção a todos os países e evocado pelo movimento republicano brasileiro em 1870. Era o nascimento de um princípio de política externa norte-americana perante o continente, ainda que não estivesse pronto para exercê-lo (Souto Maior, 1993, p.335; Santos, 2004, p.59).

Alijada desse certame, a Monarquia brasileira era um símbolo de distinção em um continente majoritariamente republicano. $\mathrm{O}$ Brasil foi visto de outra forma, se comparado aos demais países do continente, no tocante à legitimidade de seu regime político, certamente um fenômeno que contribuiu para o afastamento e o surgimento de conflitos entre eles. As intervenções em território estrangeiro ao longo do século XIX representam essa diferença, em que a política externa do país se baseava em um "imperialismo consciente", sustentado pela crença na superioridade civilizacional brasileira em face das turbulências hispânicas (Ribeiro Júnior, 1984, p.157). Nesse esteio, a diplomacia exerceu papel representativo ou ainda significou o suporte institucional para a escrita de uma história que tinha padrões civilizacionais europeus, no caso do Instituto Histórico e Geográfico Brasileiro, nas lutas pela unidade territorial e no simbolismo da dinastia e do poder moderador, todos fundamentos do campo político brasileiro (Malatian, 2001, p.10). 
Mesmo recebendo o convite para participar do encontro interamericano em 1826, o governo brasileiro resolveu não comparecer, pois desconfiava de um plano contra seus interesses em relação ao tráfico de escravos, e tal postura se manteve ao longo de todos os encontros promovidos: 1847, 1855 e 1864. Os congressos interamericanos e as propostas formuladas ao longo do século XIX possuíram pontos permanentes de debate, como a proposta de união dos Estados americanos, a criação de uma coordenação geral, a busca por uma solução pacífica para as controvérsias entre eles e a defesa coletiva contra agressões externas. O Brasil não se interessava por essas questões, eminentemente políticas e antieuropeias, recusando-se a participar e oscilando de uma postura reticente, temendo a formação de alianças contra seus interesses, a uma atitude notadamente desinteressada, ainda que estivesse mais preocupado com suas questões internas (Santos, 2004, p.74, 101). Já em meados da década de 1880, os conflitos ideológicos entre o bolivarismo, posicionamento derivado da iniciativa de Bolívar, e o monroísmo norte-americano, que passou a intervir nos conflitos fora de seu território, contribuíram para que o posicionamento brasileiro se solidificasse à parte desses. A visão de mundo da diplomacia brasileira em relação ao seu continente fazia-se mostrar nos momentos que antecederam a participação na Conferência de Washington, em 1889, traçando o receio ao americanismo e seguro quanto à manutenção das relações com a Europa. As palavras a seguir são do conselheiro João Alfredo, ministro da Fazenda em 1889:

A Conferência é exclusivamente americana e o seu plano parece conduzir até certo ponto a uma limitação das relações políticas e comerciais dos Estados independentes da América com os da Europa, dando ao Governo Americano o começo de protetorado que poderá crescer em prejuízo dos outros Estados. O Brasil não tem interesse em divorciar-se da Europa; bem ao contrário, convém-lhe conservar e desenvolver as suas relações com ela, quando mais não seja para estabelecer um equilíbrio exigido pela necessidade de manter a sua forma atual de Governo (apud Azevedo, 1971, p.189). 
A Monarquia era a antítese do americanismo disseminado no continente, mesmo que este vestisse roupagens não homogêneas, e, apesar do aceite ao alvitre interamericano, a relutância e o desconforto brasileiros eram notáveis, produzindo uma série de ambiguidades. A primeira delas era o desejo brasileiro de se aproveitar da fase de alta industrialização pela qual atravessavam os Estados Unidos, considerando que a Conferência seria uma oportunidade de diversificação das importações e das exportações, além de o País poder afirmar a solidez da Monarquia em meio ao ressurgimento do republicanismo e do descontentamento militar, que engrossavam as críticas a um governo não aberto a mudanças (Magnoli, 1997, p.195; Santos, 2004, p.112-4).

Salvador de Mendonça, à época cônsul do Brasil em Nova York, foi designado para organizar a missão especial do país na Conferência, composta também por Amaral Valente e Lafaiete Rodrigues Pereira, este último o chefe da delegação. O Brasil chegava à Conferência tendo o Chile como parceiro, ambos resistindo à aprovação do ponto relativo ao arbitramento obrigatório. $\mathrm{O}$ vizinho andino havia vencido o conflito contra o Peru e a Bolívia, conquistando áreas importantes, e temia uma rediscussão da questão, defendendo, como o Brasil, o arbitramento facultativo, algo contrário aos objetivos do encontro interamericano (Mendonça, 1913, p.106). A mesma postura pode ser observada nos demais pontos presentes na pauta do evento: o primeiro, concernente à prosperidade comum dos países americanos, não encontrava respaldo no Império receoso e conservador, que não toleraria assistir a uma República restringindo sua liberdade de negociação internacional, conduzindo ao segundo ponto, de uma possível união aduaneira americana. Ainda que a opinião de Salvador de Mendonça fosse minoritária e pró-integração, a diplomacia brasileira não via complementaridade entre as economias americanas, o que impedia um acordo de âmbito continental. Nos próximos pontos, tocantes à comunicação portuária, à adoção de um sistema uniforme de pesos e medidas, à extradição de criminosos, aos direitos autorais e a uma moeda comum interamericana, a estratégia do Império era não negociar multilateralmente, pois a atual configuração do Direito 
Internacional satisfazia o Brasil (Santos, 2004, p.119-22). O sétimo e último ponto, ${ }^{12}$ referente ao plano de arbitramento obrigatório, era bem claro para a diplomacia brasileira:

O arbitramento, que se apresenta no ato do Congresso logo em primeiro lugar, como se fosse o assunto mais importante, não constitui realmente o objeto principal da Conferência, como depois se verá, mas é importante, e será de muita gravidade, se o Governo Americano, que tende de algum tempo a assumir uma espécie de protetorado sobre os Estados da América, tiver a pretensão de ser escolhido como árbitro perpétuo (Alfredo apud Azevedo, 1971, p.189).

O grande promotor do evento era James Gillespie Blaine, secretário de Estado dos Estados Unidos em 1881 e de 1889 a 1892. Blaine havia redirecionado a política externa norte-americana, retirando o país do isolamento e aproveitando a discussão das iniciativas interamericanas pela imprensa, que cunhava, em 1882, uma nova expressão para designar a união dos países americanos: "pan-americanismo" (Santos, 2004, p.64; Bueno, 1995, p.15-9). O pan-americanismo, a essa altura, não possuía um sentido acabado, ou seja, de uma representação ideológica e uma prática política que significavam a transição da hegemonia britânica para a norte-americana na América. A cunhagem da expressão baseava-se na unidade hemisférica fundada sob influência dos Estados Unidos que determinou a inserção do continente no sistema internacional de Estados (Magnoli, 1997, p.198-9). À luz dessas considerações, o enquadramento da política externa brasileira na moldura do pan-americanismo não pode ser associado ao período da proclamação da República, pois o significado que a expressão assumiu, como uma visão de mundo e doutrina diplomática, somente foi vigente nos anos em que Rio Branco esteve à frente do Ministério das Relações Exteriores, entre 1902 e 1912.

12 Havia um oitavo ponto na pauta que trataria dos "assuntos que digam respeito à prosperidade dos diversos Estados presentes à Conferência e qualquer deles julgue oportuno submeter à sua apreciação” (Azevedo, 1971, p.187). 
Antes desse período, o que ainda valia era a releitura da Doutrina Monroe (Magnoli, 1997, p.207; Pecequilo, 2003, p.65).

Na prática, a Conferência de Washington adquiria um sentido diferente das outras iniciativas interamericanas. Blaine compartilhava do receio de uma intervenção europeia na América depois de diversos conflitos continentais e desejava ampliar as áreas de influência econômica dos Estados Unidos, carentes de mercados para o escoamento da alta produção manufatureira. No discurso de abertura da Conferência (Azevedo, 1971, p.190-2), em 2 de outubro de 1889, Blaine ressaltou que a larga extensão geográfica do continente americano e a diversificada condição produtiva deveriam despertar simpatias e deveres comuns aos Estados, mas até então poucas medidas haviam sido tomadas. O secretário ainda destacava que a existência de interesses comuns e firmados por meio da diplomacia permitiria conduzir a um equilíbrio de poder entre a Europa e a América, e seu contrário poderia fomentar os conflitos e sentimentos de inimizade entre as duas áreas. ${ }^{13}$

A leitura do discurso de Blaine permite entrever parte do posicionamento norte-americano sustentado pelo monroísmo, que se camuflava nas ideias de igualdade e cooperação, mas que visava, sobretudo, criar um mercado para seus produtos utilizando tanto a arbitragem como os tratados de reciprocidade comercial. Assim agia o imperialismo norte-americano na ocasião, procurando naturalizar a ideia de autonomia e separação irreparável dos sistemas europeu e americano de Estados, o que, ao fim, era a diferenciação entre o Novo e o Velho Mundo (Pecequilo, 2003, p.68-70).

Logo que as primeiras discussões foram travadas, a delegação brasileira recebeu o telegrama anunciando a proclamação da República, tornando o Brasil o centro das atenções da Conferência (Bandeira, 1973, p.130). Salvador de Mendonça, tendo recebido a notícia por

13 Magnoli(1997, p.150, nota 15) elucida a ideia: "Do ponto de vista metodológico, é importante sublinhar que o equilíbrio de poder não constitui uma meta dos atores envolvidos, que buscam sempre, por considerações de segurança, a própria hegemonia. O equilíbrio de poder estabelece-se, eventualmente, como consequência da incapacidade dos oponentes em imporem uma hegemonia". 
intermédio de James Blaine, chegou a hesitar sobre a verdade dos fatos e o modo pelo qual a mudança havia sido conduzida. De acordo com suas palavras, relutou porque preferia que a República viesse efetivamente pela via eleitoral, feita no Parlamento e com o voto da maioria da nação, expondo seu posicionamento republicano "evolucionista" (Mendonça, 1913, p.112-3).

Com a notícia em mãos, o chefe da delegação brasileira, Lafaiete Rodrigues Pereira, demitiu-se do cargo, ocupado por Salvador de Mendonça a pedido do ministro das Relações Exteriores do governo provisório, Quintino Bocaiúva. ${ }^{14}$ Em 19 de novembro, enviou um telegrama saudando o novo regime: "Saúdo governo provisório. Aguardo ordens em relação à Missão Especial e Congresso. Providência quanto a Congresso Urgente" (Mendonça apud Azevedo, 1971, p.193). Ele acreditava que as instruções dadas pelo gabinete imperial à missão brasileira estavam em desacordo com os demais países da América (com exceção do Chile) e os Estados Unidos, isolando-a no âmbito do Congresso, levando-o a perguntar se poderia "dar interpretação republicana às instruções monárquicas e notadamente se podia aceitar e trabalhar pelo arbitramento obrigatório", obtendo resposta positiva (Mendonça, 1913, p.135-6). O pedido de Salvador de Mendonça representava algo presente no segmento republicano brasileiro, simpático às instituições dos Estados Unidos, tendência à qual ele próprio era filiado.

Se à época de publicação do Manifesto do Clube Republicano já se faziam reivindicações em prol da união do elemento geográfico (o continente) com o elemento político (o regime republicano) para o futuro do país, em 1889, quando o regime foi proclamado, tal visão de mundo foi imediatamente colocada em prática: era a "correção necessária dos males do passado”, na visão dos republicanos (Bueno, 1995, p.28).

Entretanto, para que o Brasil continuasse a deliberar na Conferência, foi preciso lutar para obter o reconhecimento do novo

14 A partir de 1889, com a mudança de regime, o antigo Ministério dos Negócios Estrangeiros passa a se chamar Ministério das Relações Exteriores (Castro, 1983, p.4). 
regime pelos países ali representados, o que o fragilizou no certame, se considerado que o advento da República não havia sido acolhido com fervor e unanimidade pelos países europeus e por determinados segmentos da opinião pública norte-americana. A imprensa dos Estados Unidos, por exemplo, simpática ao imperador D. Pedro II desde sua visita ao país em 1876, considerou o banimento da família real uma arbitrariedade e passou a atacar sistematicamente o governo provisório, criticando o caos e a desorganização dominantes desde então. Tanto a imprensa da França como a da Inglaterra criticaram severamente os riscos que uma mudança de regime político traria para o Brasil, que, por sua vez, não poderia arcar com os compromissos econômicos internacionais caso a instabilidade perdurasse (Bueno, 1995, p.42; Vinhosa, 1993, p.282).

Observa-se que a busca pelo reconhecimento do regime proclamado se sobrepunha a outro objetivo: a formação de um novo comportamento político que passasse a distinguir o país de seu passado recente, antiamericano e monarquista. $\mathrm{Na}$ visão dos republicanos, até então a Monarquia havia colocado o Brasil na contramão de um movimento histórico de construção dos Estados nacionais cujos governos seriam a representação das vontades coletivas e não da vontade dos soberanos. O momento agora era de reconciliação com o continente, e, para tanto, colaborar com a perspectiva dos Estados Unidos era indispensável para o desenvolvimento de uma cultura política republicana (Santos, 2004, p.133).

Apoiando-se nesse processo de criação de novas referências políticas, Salvador de Mendonça lutou com James Blaine para obter o reconhecimento da República brasileira pelos Estados Unidos, a "República-mãe". ${ }^{15}$ Contudo, uma série de desentendimentos impediu que tal ação fosse imediata, trazendo à tona a falta de diálogo entre os representantes brasileiros e os receios norte-americanos. A correspondência de Amaral Valente ao Ministério das Relações Exteriores é ilustrativa nesse sentido:

15 A expressão é de Quintino Bocaiúva em entrevista a um repórter norte-americano em 31 de dezembro de 1889 (Bueno, 1995, p.109). 
Em uma entrevista que tive ontem com o Sr. Secretário de Estado a respeito dos recentes acontecimentos políticos do Brasil [...] Ao terminar deu-me S. Ex. a a perceber que o seu desejo de reconhecer o Governo Provisório, consultando-me quanto à sua oportunidade [...] O Sr. Blaine, avistando-se comigo mais tarde, disse-me que tendo pensado sobre o caso, resolvera expedir instruções ao Sr. Adams para manter com o Governo Provisório relações diplomáticas, acrescentando em seguida que esperava continuar, como dantes, as nossas relações de perfeita cordialidade $[\ldots]^{16}$

Paralelamente, Salvador de Mendonça relatou que, após conferenciar com Blaine, comunicou ao Ministério das Relações Exteriores que poderia obter o reconhecimento formal da República pelos Estados Unidos, fato prontamente respondido por Quintino Bocaiúva, dizendo que isso já tinha sido feito pelo representante norte-americano no Brasil, Robert Adams. Dias depois, Blaine declarou a Salvador de Mendonça que Adams havia se excedido quanto às instruções dadas pelo Departamento de Estado e que o presidente Harrison não o acompanhava na decisão de reconhecer formalmente a República brasileira, o que seria feito somente após a manifestação da maioria do povo brasileiro por sua manutenção (cf. Mendonça, 1913, p.118). O Congresso norte-americano receava uma reviravolta na situação, agravada pelo fato de a chefia do governo provisório estar nas mãos de um militar que poderia se aproveitar para encabeçar uma ditadura, como ocorria com frequência nos países sul-americanos (Bandeira, 1973, p.129). ${ }^{17}$ Internamente, a perspectiva do governo provisório era negativa, acreditando que a demora no reconhecimento poderia fomentar projetos restauradores organizados pelos monarquistas. Nos Estados Unidos, Salvador

16 Carta de Amaral Valente a Quintino Bocaiúva, em 20 de novembro de 1889 (cf. Azevedo, 1971, p.177).

17 Bandeira (1973) mostra que o desejo pelo reconhecimento era exclusivo de Blaine, que só arrefeceu quando Adams passou a não ver mais segurança no regime, que passava por problemas internos, demonstrando pouco respeito à opinião do povo. 
de Mendonça (1913, 132-3) se encarregou de defender o regime brasileiro, como o fez na reunião da União Comercial HispanoAmericana, em dezembro de 1889:

A transformação do Império brasileiro em Estados Unidos do Brasil não é um mero acidente da vida dos partidos políticos, produto inesperado de um pronunciamento militar: é o resultado lógico (era preciso então que por honra nossa, dizer isso lá fora), da evolução histórica do progresso de uma nacionalidade na estrada ascendente da liberdade e da civilização. [...] Era chegado o momento em que a evolução política, iniciada havia quase um século, se completava [...] encerrou-se um ciclo histórico com essas portas de bronze que nenhum esforço humano poderá jamais abrir. A República do Brasil está feita e ninguém a poderá desfazer.

Nesse discurso, percebe-se a ideia que o diplomata brasileiro tinha acerca do regime como um republicano evolucionista: enxergava a República como resultado lógico da história do País, o que tornava a mudança algo natural. Essa concepção trazia em si uma dupla resposta: a defesa da irreversibilidade do regime e o esforço em fragmentar os temores norte-americanos e europeus acerca de sua instabilidade. A ideia de que a evolução política havia se iniciado havia quase um século garantia, por fim, o acúmulo de experiência necessário à boa condução do regime republicano.

Em janeiro de 1890, Salvador de Mendonça foi informado que nenhuma potência europeia reconheceria a República brasileira antes que os Estados Unidos o fizessem, atitude que corroborava o reconhecimento da Europa sobre a alocação da América do Sul como órbita de influência dos Estados Unidos e, por consequência, legitimava a ação monroísta (Bueno, 1995, p.109). Ele voltou-se, então, à delegação norte-americana presente na Conferência, mostrando-lhes a oportunidade que eles teriam de ser os "padrinhos do batismo político brasileiro" e conferenciou com Blaine, que atentava para a fragilidade brasileira e gerenciava a necessidade política (o reconhecimento) somente com Salvador de Mendonça. A leitura da 
correspondência entre Blaine, Charles Flint (delegado dos Estados Unidos na Conferência) e Salvador de Mendonça permite inferir que havia preferência pelo diplomata residente nos Estados Unidos desde 1875, o qual Blaine conhecia desde seu primeiro mandato como secretário de Estado, ao contrário de Amaral Valente, que possuía as credenciais necessárias para fazê-lo (cf. Mendonça, 1913, p.120-2).

O reconhecimento dos Estados Unidos viria após muitas hesitações e lutas políticas internas e externas. A missão brasileira no Rio da Prata era o sintoma de como o novo regime carecia de experiência política e de um processo de racionalização, ao contrário do romantismo que inspirava muitos diplomatas e republicanos. Não bastasse o Brasil estar presente na Conferência de Washington e a monarquia ruir, havia uma disputa territorial com a Argentina que se arrastava desde 1880, referente à região de Palmas (ou Missões) situada entre Santa Catarina e o Paraná. Em visita a Montevidéu, Quintino Bocaiúva declarou que a região, na visão brasileira, poderia ser dividida em duas partes iguais para que a política na região fosse marcada pelo amplo espírito de fraternidade americana.

A recepção da notícia na Argentina foi de vitória diplomática. Já no Brasil, as críticas da imprensa (sobretudo a monarquista) ao governo provisório multiplicaram-se, acusando-o de irresponsabilidade e inexperiência diplomática. Esses fatos persistiram até a formação da Assembleia Constituinte em 1890, que não aprovou o acordo proposto por Bocaiúva, o qual, mais tarde e certamente pressionado pela declaração inoportuna, postou-se contrariamente à sua proposta (Bueno, 1995, p.97-8). ${ }^{18}$ A querela internacional foi retomada sob responsabilidade de Rio Branco e arbitrada favoravelmente ao Brasil pelo presidente norte-americano Grover Cleveland em 1895. ${ }^{19}$

18 O tratado que dividiu a região em duas partes iguais entre Brasil e Argentina ficou conhecido como Tratado de Montevidéu, celebrado em 25 de janeiro de 1890 (Magnoli, 1997, p.206).

19 Essa questão será retomada no Capítulo 2, pois foi argumento utilizado na manutenção do acordo comercial com os Estados Unidos que tendia a ser desfavorável ao Brasil. 
Em 29 de janeiro de 1890, Salvador de Mendonça enviou telegrama a Quintino Bocaiúva informando-lhe acerca do reconhecimento:

[...] Governo Americano reconheceu República Brasil fomos hoje recebidos em audiência solene. Congratulo-me convosco pelo reconhecimento das novas instituições de nossa Pátria pelo Governo dos Estados Unidos da América. Peço-vos que aceitei a segurança de meu profundo respeito e subida consideração. - Salvador de Mendonça (apud Azevedo, 1971, p.180).

Após o reconhecimento, o Brasil retomou intensamente sua participação na Conferência Internacional Americana. Salvador de Mendonça já havia inquirido se poderia dar interpretação republicana às ações da delegação brasileira, e, para tanto, a primeira ação foi reverter o posicionamento em relação ao arbitramento obrigatório que vinha sendo discutido conjuntamente a um projeto de abolição de conquista (Santos, 2004, p.125). Nessa fase da Conferência, os delegados brasileiros passaram a colaborar intimamente com os argentinos e norte-americanos na elaboração do projeto de arbitramento, salvo que os últimos eram tenazmente contrários à abolição da conquista, arranjo que a representação brasileira, na pessoa de Mendonça, teve que lutar para a aprovação. Em reunião com Salvador, Blaine mostrou sua insatisfação em relação a tal ponto, ao passo que o brasileiro se dirigiu aos representantes de outros países que sugeriram a retirada da Conferência e a recusa na assinatura de qualquer ponto (cf. Mendonça, 1913, p.144-5).

Insistindo pela votação liderada pelas delegações do Brasil, composta por Salvador de Mendonça e Amaral Valente, e da Argentina, integrada por Manuel Quintana e Roque Sáenz Peña, a sessão da Conferência aprovou o projeto de arbitramento obrigatório em 18 de abril de 1890, incluindo a cláusula de abolição de conquista. Esse projeto seria recomendado para aprovação aos congressos dos países americanos que assinariam e ratificariam o documento. O prazo para confirmação do tratado era de um ano, quando as delegações deveriam entregar os pareceres de suas casas legislativas, o que não 
ocorreu. O posicionamento das delegações americanas mostrava o quão relativo era o sentimento de união dos Estados americanos, que à época já haviam visto o poder de intromissão norte-americana em seus territórios e receavam toda e qualquer atitude vinda da potência do norte, as quais eram encaradas como imposições e ações imperialistas.

Os representantes presentes na Conferência reconheciam que a não assinatura de um projeto de arbitramento e abolição de conquista poderia refletir em políticas intervencionistas, porém escolheram o afastamento, certamente sob temores de formação de um protetorado norte-americano no continente, tal como previa o conselheiro João Alfredo de Oliveira nas instruções dadas à delegação do Império do Brasil que se dirigia ao evento em 1889.

Entusiasmado pelo "espírito de solidariedade americana", o Brasil aproveitou, em parte, essas deliberações da Conferência em sua primeira Constituição republicana, promulgada em 1891, recomendando o arbitramento como recurso para as questões litigiosas (Mendonça, 1913, p.150-2).

A questão discutida no certame e que permaneceu na agenda da política exterior brasileira e norte-americana foi, contudo, outra. Como as propostas para a intensificação do comércio interamericano por meio de tratados não atingiram o plano prático, resolveu-se criar um bureau com sede nos Estados Unidos que reuniria informações dessa ordem sobre os países do continente, a fim de que taxas e produtos exportados fossem conhecidos e seus mercados expandidos. O obstáculo na deliberação de acordos bilaterais na Conferência era justificado pelo fato de que o não pagamento das tarifas aduaneiras, previstas nos acordos, retiraria uma importante fonte de renda dos países sul-americanos. Não por acaso alguns dos mais veementes combatentes ao ponto foram os argentinos Quintana e Peña (Santos, 2004, p.126).

O significado da realização da Conferência no âmbito americano, e especialmente para o Brasil, foi que, do lado norte-americano, sua aproximação com o restante do continente não seria explicada pela simpatia política ou geográfica, pois a necessidade de alargamento dos 
mercados de seus produtos era urgente, dada a alta produtividade e a saturação do mercado consumidor interno. Paralelamente, centralizavam a aplicação de seus recursos no crescimento do contingente militar, que teria um efeito vital sobre o comércio, expandindo-o e o fiscalizando (Schoults, 2000, p.109).

As ações da política externa norte-americana para a América Latina se moldaram a partir dessas circunstâncias e não abandonaram os argumentos políticos monroístas, camuflados no imperialismo econômico que se objetivava nos acordos comerciais. No horizonte brasileiro, a participação no encontro como uma Monarquia já era novidade depois das recusas anteriores, e a mudança de regime criou um cenário favorável aos Estados Unidos e de fragilidade para os brasileiros, que, por intervenção de Salvador de Mendonça, interpretaram a situação de forma idealista, sem se atentar para as dificuldades que o advento da República poderia trazer naquele momento.

Uma das dificuldades era a inexperiência dos homens que compunham o governo provisório, que ascenderam ao poder abruptamente, sem nenhum planejamento ou estratégia para o País, deixando tão somente a cargo dos diplomatas a "formulação" da política exterior. Ao perder a peculiaridade de única Monarquia no continente, o Brasil passou a ver a ideia republicana firmemente associada à americana, tornando-as um par político indissociável. Passando de uma posição defensiva à estreita cooperação com norte-americanos e argentinos, Salvador de Mendonça foi destacado pelos representantes de outros países e pela imprensa dos Estados Unidos não somente pela atuação em prol da votação dos pontos acerca do arbitramento e abolição de conquista, mas, sobretudo, pelo reconhecimento da República do Brasil pelos Estados Unidos (cf. Mendonça, 1913, p.126; Bueno, 1995, p.111). Seu discurso de encerramento na Conferência permite compreender como a diplomacia brasileira interpretava aquele momento de forma idealista:

Não se pode negar que a Causa Suprema dos direitos humanos chame-se causa providencial ou lei histórica [...] esse Poder Supremo que ao resplandecer da alvorada do próximo século, que apenas nos 
separa uma década, não se descubra já nenhuma possessão na terra livre da América; que as colônias que a conquista encadeou deste lado do Atlântico se tenham transformado em Estados independentes.

Temos ouvido algumas vezes no recinto de nossas reuniões frases talvez demasiado altivas, porém sempre reveladoras fiéis da livre opinião dos povos livres por nós outros representados. Nunca, no entanto, viu-se em perigo sequer por um momento, a solidariedade do pensamento com que todos nós, cheios de aspirações generosas e elevadas, e com a mira fixa no futuro, trabalhou à porfia para que nossas Pátrias pudessem dar ao mundo o maravilhoso espetáculo da concórdia de um continente inteiro, dedicando às artes da paz e sem outra rivalidade senão a de alcançar o primeiro posto no Panteão da Democracia (apud Azevedo, 1971, p.204).

Nos anos seguintes, a aproximação com os Estados Unidos se efetivaria por intermédio de Salvador de Mendonça, que não poupou esforços em levar ao Brasil as referências econômicas e políticas necessárias à estabilização do regime. Iniciava-se o período em que a expressão "a América para os americanos", originária do discurso de Monroe em 1823 e aproveitada no Manifesto de 1870, era colocada em prática, e as circunstâncias determinariam sua aplicação. 


\section{2 \\ ReLACIONAMENTO BRASIL-ESTADOS UNIDOS}

\section{As negociações e a assinatura do Tratado de Reciprocidade de 1891}

A expansão econômica dos Estados Unidos no final do século XIX foi sentida pelo Brasil, que procurava novas bases de sustentação política. A partir da característica fundamental de sua economia, a exportação de produtos agrícolas, o Brasil procurou buscar o apoio necessário para a manutenção das novas instituições políticas, indo ao encontro dos interesses estratégicos norte-americanos de alargamento dos seus mercados consumidores e fornecedores. A diplomacia brasileira, na figura de Salvador de Mendonça, vivenciou momentos peculiares e delimitadores dessa iniciativa, gerando posicionamentos de defesa e ataque por parte da imprensa e intelectuais do Brasil, denotando a fragilidade do novo regime.

A aproximação com os Estados Unidos datava do início do século XIX e não foi, ao todo, harmoniosa (Bandeira, 1973, p.11; Magnoli, 1997, p.178-9). Pelo contrário, a relação com o Brasil atendeu a interesses estratégicos nos sentidos econômico e político, desenrolando-se, às vezes, em posturas diplomaticamente agressivas, como quando os norte-americanos desejaram a abertura à livre navegação do Rio Amazonas e durante a Guerra do Paraguai, posicionando-se 
a favor do governo paraguaio. O primeiro exemplo, já abordado no Capítulo 1, era o ponto de partida no campo sul-americano da "diástole colonialista" dos Estados Unidos, e a diplomacia brasileira encarava as pressões norte-americanas como tentativas camufladas de anexação daquela porção territorial, tal como havia ocorrido alguns anos antes no Texas e na Califórnia (Bandeira, 1973, p.87). No conflito brasileiro com o Paraguai entre 1865 e 1870, o representante dos Estados Unidos no governo paraguaio colocou-se à disposição de López, fato que levou à suspensão temporária das relações com o Brasil, que, por sua vez, havia apoiado tacitamente os confederados na Guerra de Secessão norte-americana e que foram derrotados em 1865 (Mendonça apud Azevedo, 1971, p.380).

O expansionismo territorial passou a ser perseguido pela política externa norte-americana, sustentada pela doutrina do Destino Manifesto. Interpretando-o como um repertório ideológico que aliava o enriquecimento material à ideia de povo "eleito por Deus", o Destino Manifesto norte-americano se configurava também como uma doutrina de predestinação geográfica e uma base de legitimação para as conquistas territoriais e violações de soberania no restante do continente. Em outras palavras, a aplicação dessa ideia de predestinação à conquista implicava a sublimação da história, ou seja, a sua inscrição em tempos indefiníveis, revelando sua fragilidade legal. O intervencionismo característico da política externa dos Estados Unidos no século XIX, representado pela conquista de territórios no México e na América Central, poderia estar justificado, em parte, pelo Destino Manifesto na medida em que dispensava a argumentação lógica e remetia a uma "lei natural, anterior à existência de uma sociedade política” (Magnoli, 1997, p.21-4).

Portando, a diplomacia norte-americana encontrava obstáculos ao se aproximar do Brasil no sentido político, apesar de o comércio entre os dois países, focados na exportação brasileira de café, encontrarse em fase de crescimento desde a década de 1860 (Bandeira, 1973, p.116; Pinto, 1984, p.142). Esse afastamento político encontrava sua fundamentação possivelmente na estruturação dos regimes políticos de cada um dos países, que possuíam bases de legitimida- 
des distintas. Os Estados Unidos definiram, no final da década de 1860, portanto, após a Guerra Civil, seu território e a concepção de união norte-americana, integrada a partir da política e da economia (agropecuária e a industrialização) e colocada em prática sobretudo pela revitalização da Doutrina Monroe, que passou a balizar seu comportamento ante os demais países americanos, tratados como inferiores culturalmente. Esse tipo de atitude encontrava aquiescência do povo norte-americano, que alegava serem piores todas as alternativas de dominação que não fossem as dos Estados Unidos (Schoults, 2000, p.111). Assim, a formação de um discurso comum entre opinião pública e poder político, entre ideias e práticas voltadas à intervenção, legitimava a postura exterior norte-americana, criando a imagem de país-ameaça nos governos sul-americanos, inclusive no Império brasileiro.

A despeito da semelhança do dilatado território com os Estados Unidos, o Brasil trilhava outro caminho na construção de uma identidade específica a si e para seu povo. O Império dava continuidade a um Destino Manifesto luso-brasileiro herdado do período de colonização e que significava a priorização das ações estratégicas de manutenção do território nos estuários do Rio da Prata e amazônico, posição que gerou conflitos diretos com Paraguai, Argentina e Uruguai (Magnoli, 1997, p.84-90).

O Destino Manifesto aplicado à realidade brasileira é utilizado por Demétrio Magnoli (1997) para comparar as ações de conquista e intervenção brasileiras na região sul-americana. De forma similar aos Estados Unidos, os políticos brasileiros se utilizavam de argumentos ideológicos para a interferência nas bacias hidrográficas do Rio da Prata e do Amazonas com o fito de prover a manutenção e o alargamento territorial. As semelhanças param nesse ponto, pois essa postura diferia profundamente dos norte-americanos, que valorizavam a descontinuidade com o passado colonial no momento da independência.

No Brasil, a elaboração do nacionalismo, realizada no ambiente histórico do Império manipulou os signos da continuidade, construindo uma identidade nacional e um sentido de destino ampara- 
dos no passado. Sob esse aspecto, os mitos fundadores brasileiros distinguem-se radicalmente dos americanos, cuja fonte é a ideia de ruptura. A distinção reflete trajetórias históricas e geopolíticas contrastantes (Magnoli, 1997, p.94).

Nos Estados Unidos, três pilares davam significado à ruptura: o geográfico, com a separação entre o Novo e o Velho Mundo; o ideológico, pela instalação do contrato social ao invés das dinastias; e, por fim, o institucional, pela fundação da República, em oposição à Monarquia. No Brasil, a continuidade advinda da independência foi a conclusão do ato de transferência da sede do Império da Europa para a América. Nesse sentido, o Brasil independente sustentava-se na afirmação do Brasil português.

A posição brasileira ante a região definia-se coberta com um suposto manto de superioridade cultural, que se sustentava principalmente na figura do imperador e da Monarquia, elementos associados pelas elites imperiais à estabilidade política do Brasil, em contraste com a difícil trajetória das ex-colônias espanholas na América, permeadas de inúmeros conflitos internos. Esses segmentos de elite, membros do campo político, procuraram, por fim, consolidar a noção de um Estado que preservasse intacto o território nacional, sustentando-se na fidelidade ao governante e ao governo (Lessa, 2008, p.243).

A trajetória distinta entre Brasil e Estados Unidos não permitiu uma aproximação que não no sentido comercial, em que a exportação de café adquiria cada vez mais importância para a economia brasileira, passando inclusive a refletir nas decisões da Monarquia: a livre navegação no Rio Amazonas foi permitida em 1866, e a entrada de imigrantes dos Estados Unidos passou a crescer na mesma época (Bandeira, 1973, p.118-21). ${ }^{1}$

A referência aos Estados Unidos e à sua República como paradigmas somente foi apontada na década de 1870, pelo movimento republicano. Seus membros priorizaram a constituição de uma pauta

1 Em 1872, o Congresso norte-americano isentou o café brasileiro do pagamento de direitos na entrada no país. 
alternativa às referências europeias e se voltaram para seu próprio continente. Por meio da retórica da solidariedade americana, os republicanos brasileiros indicavam que os Estados Unidos poderiam ser utilizados como exemplo na organização de um governo federalista pautado na autonomia das províncias.

Anos mais tarde, o movimento republicano brasileiro amainava em razão das disputas internas pelo controle do partido e pela ascensão dos gabinetes liberais, que procuravam aplicar reformas na organização do Estado monárquico e na discussão sobre o abolicionismo. Nesse ínterim, a política externa imperial em relação aos Estados Unidos conheceu uma relativa aproximação por ocasião da visita do imperador à exposição da Filadélfia em 1876, presença que havia resultado em troca de elogios de ambas as partes, cada vez mais próximas em relação ao comércio do café. $\mathrm{O}$ viés econômico foi diretamente explorado no governo de Grover Cleveland, já sob a atuação de Salvador de Mendonça, quando o presidente norte-americano propôs o estabelecimento de um zollverein ${ }^{2}$ em 1887. Levando ao conhecimento do diplomata brasileiro o amplo desequilíbrio das relações comerciais entre os dois países a favor do Brasil, o presidente declarou a Salvador de Mendonça que "[...] as duas maiores nações deste continente não podiam manter esse estado de coisas". Completou dizendo que os bons negócios faziam os bons amigos e que sua intenção era ampliar a amizade entre os países, indo além da Doutrina Monroe (Mendonça, 1913, p.82; Bueno, 1995, p.118). A intenção do presidente norte-americano traduzia interesses de industriais e produtores agrícolas de todo seu país. Com o mercado interno saturado e carente de consumidores, uma alternativa viável seria o Brasil, que centralizava suas importações na Europa.

Salvador de Mendonça descrevia que o Brasil importava dos Estados Unidos apenas uma oitava parte da mesma ação por parte

2 Zollverein é o termo (em alemão) para designar um tipo de união aduaneira, que tem por objetivo a constrição de uma área de comércio comum entre territórios, Estados ou bloco de países. Nesse tipo de associação internacional, estabelece-se uma tarifa aduaneira (proveniente do comércio) comum entre seus membros. 
deles, implicando severa desigualdade. No entanto, era sabido que os norte-americanos já se encaminhavam para se tornar o maior mercado consumidor de café do mundo, e o Brasil, seu maior produtor. ${ }^{3}$

Ainda na reunião com Cleveland, o diplomata brasileiro ouviu do presidente que a intenção dos Estados Unidos de estabelecer um tratado de comércio com o Brasil poderia servir de modelo a outros acordos que possivelmente seriam discutidos em uma reunião de representantes de países americanos. Perguntado sobre os "termos" do tratado, Cleveland respondeu a Salvador de Mendonça que desejava a mais absoluta liberdade de comércio entre os dois povos, de modo a serem trocados todos os nossos produtos sem nenhum imposto ou taxa, como já sucedia com o café e a borracha (cf. Mendonça, 1913, p.83). Salvador de Mendonça contrapôs o presidente dizendo que tal acordo privaria o Brasil das rendas aduaneiras, ao passo que o norte-americano mostrou os benefícios da substituição das importações brasileiras da Grã-Bretanha e da Europa pelas norte-americanas, cujas manufaturas se equivaliam (cf. Azevedo, 1971, p.147-8).

O diplomata encontrou-se com o imperador e expôs-lhe a proposta, a qual foi recebida com simpatias. O imperador havia visitado os Estados Unidos em 1876 e se tornou simpático ao povo norte-americano, fato salientado pelo presidente Cleveland, que viu benefícios políticos na efetivação de um tratado comercial bilateral. No Brasil, Salvador de Mendonça reuniu-se com o barão de Cotegipe, ministro dos Negócios Estrangeiros, e Francisco Belisário, da Fazenda, a fim de discutir a proposta norte-americana e elaborar estudos que engendrariam uma declaração a ser incluída no orçamento imperial, figurando no artigo $2^{\circ}$ da Lei n⿳‥ 3.396, de 24 de novembro de 1888:

Fica o Governo autorizado:

A rever as tarifas da Alfândega relativamente aos gêneros importados dos Estados Unidos, nos termos do tratado que porventura

3 Na década de 1880-1890, o Brasil produzia 56,63\% do café mundial, representando $61,5 \%$ das exportações do país, aproximadamente 52.000 sacas do produto (Pinto, 1984, p.139). 
celebrar com esta nação para obter vantagens pelo menos recíprocas para gêneros de produção nacional por ela importados (Azevedo, 1971, p.149).

A comissão formada para analisar o comércio com os Estados Unidos publicou, em 2 de janeiro de 1889, um ofício que serviu de base para a minuta do acordo. A avaliação feita pelo grupo indicava que a importação de alguns produtos, como o algodão manufaturado, a farinha de trigo e o querosene, sem taxação, poderia concorrer com a produção brasileira e beneficiar outras nações. No quadro da exportação, os produtos brasileiros que entravam em abundância nos Estados Unidos eram o café, a borracha, o açúcar e o cacau, e somente o terceiro pagava direitos alfandegários. Nesse sentido, a comissão indicava que, se fosse cumprir a disposição legislativa de 24 de novembro de 1888, o Brasil poderia oferecer isenção de direitos sobre o querosene norte-americano, escasso no País, pela livre entrada do açúcar brasileiro naquele mercado. A minuta elaborada continha e admitia as atividades de exportação e importação dos produtos livres de direitos mencionados previamente, considerando que o acordo duraria até que uma das partes manifestasse com um ano de antecedência a intenção de denunciá-lo. Em 19 de março de 1889, João Alfredo de Oliveira, ministro da Fazenda do Império, comunicou por meio de ofício a Rodrigo Augusto da Silva, da pasta de Negócios Estrangeiros, que Salvador de Mendonça, com estudos especiais na matéria de que se ia tratar, seria autorizado a acompanhar e ajudar as negociações do acordo (cf. Azevedo, 1971, p.150-1). Seguiu-se que o tratado foi duramente atacado pelo próprio Ministério dos Negócios Estrangeiros e no Parlamento, onde a reunião de Salvador de Mendonça com o presidente norte-americano foi até mesmo colocada em dúvida (cf. Mendonça, 1913, p.91).

A rejeição brasileira ao zollverein remetia à postura praticada ao longo de todo o século XIX, de afastamento em relação aos vizinhos e aos Estados Unidos, ainda que no final da década de 1880 tentasse apresentar-se não oficialmente como a "mais republicana das realezas", dando atenção à conjuntura internacional, demonstrando 
certo compromisso com a modernização econômica e os avanços de sua época. Entretanto, os abalos internos na estrutura imperial provocados pelo recrudescimento das críticas e das fileiras de republicanos faziam força no sentido contrário, de conservação da postura hermética perante qualquer iniciativa que extrapolasse a tradição imperial, de controle e autonomia comercial (Santos, 2004, p.143).

$\mathrm{O}$ aceite ao convite dos Estados Unidos para a I Conferência Internacional Americana marcou certa concessão da parte brasileira. Salvador de Mendonça, cônsul em Nova York, indicou o ex-republicano histórico Lafaiete Rodrigues Pereira para ser o chefe da missão e J. G. do Amaral Valente para completá-la.

Quatro meses antes do início dos trabalhos da Conferência, Salvador de Mendonça enviou ao governo brasileiro um longo memorando (cf. Azevedo, 1971, p.380-8) ${ }^{4}$ que detalhava e historiava suas ideias acerca da aproximação comercial do País com os Estados Unidos, salientando que, a partir da economia, a maciça importação de produtos europeus poderia ser prontamente equilibrada com produtos oriundos dos Estados Unidos, bons compradores dos produtos agrícolas brasileiros. Narrava também que algumas das queixas dos norte-americanos, fundadas em uma provável antipatia ao regime político do Brasil, foram dissipadas em 1876 por ocasião da visita do imperador, mas outras persistiam à medida que as relações comerciais eram unilateralmente favoráveis a este país, que exportava dois terços da sua produção de café e quatro quintos da borracha extraída para os Estados Unidos.

A tal "estado de coisas", ele apresentava os seguintes argumentos: a) havia uma rotina comercial do Império brasileiro que se encontrava engessada desde a época colonial com a Europa; b) as manufaturas europeias tinham custo menor em relação às norte-americanas; c) havia um sistema de crédito acessível dos fabricantes europeus aos importadores brasileiros; d) os norte-americanos se negavam e difi-

4 O original desse memorando encontra-se na Academia Brasileira de Letras, nos Arquivos de Salvador de Mendonça, pasta 2, com cerca de quinze páginas manuscritas. 
cultavam a venda de seus produtos a prazo; e e) não havia transportes regulares entre os portos dos dois países.

Para Salvador de Mendonça, a livre entrada de produtos agrícolas brasileiros nos Estados Unidos garantiria um amplo mercado de consumo, além de sustentar a transformação da mão de obra de seu país do elemento escravo para o livre. Os Estados Unidos já eram os maiores compradores do café brasileiro a essa época, e a ampliação da exportação de outros produtos, como o açúcar, seria capaz de restaurar a riqueza de várias províncias do norte e nordeste do país. O mercado norte-americano consumia anualmente cerca de 1.400.000 toneladas de açúcar, ao passo que produziam somente 200.000 toneladas, importando a diferença majoritariamente das colônias espanholas. Notadamente favorável ao entendimento dos dois países, Salvador de Mendonça avaliava que o tratado de comércio não deveria ficar reduzido a um acordo restritivo, como desejava o gabinete imperial, mas deveria rever convenções antigas do Direito Internacional e atribuições consulares que poderiam permitir maior flexibilidade na negociação bilateral e promover a unificação da moeda de prata dos dois países, que fixaria o câmbio e as transações alfandegárias. Por fim, considerou que caso houvesse a assinatura do tratado, este deveria ser feito antes ou em separado dos debates que ocorreriam na Conferência de Washington, pois negociá-lo em âmbito geral poderia despertar mal-estar entre os demais países ali presentes.

O memorando era claro quanto à indicação ao acordo com os Estados Unidos: para o diplomata, havia certa desconfiança da parte brasileira quanto à importação de produtos norte-americanos, e a assinatura de um tratado que permitisse a entrada desses produtos no Brasil torná-los-ia mais baratos ao consumidor brasileiro, acostumado aos produtos europeus. Como o tratado previa a cláusula de reciprocidade, a livre entrada de produtos brasileiros nos Estados Unidos não representaria dificuldades aos produtores brasileiros, pelo contrário, estimularia a produção e reativação de setores deficientes da economia brasileira. Pode-se entrever que o documento apresentado por Salvador de Mendonça ao governo brasileiro possuía 
certa dose de simpatia ao governo norte-americano e se sustentava na importância que este país vinha adquirindo perante a economia mundial. A recomendação do representante brasileiro de a negociação ser realizada fora do âmbito da Conferência indicava a busca por exclusividade pelo Brasil, que não queria se ver - mais uma vez - em meio aos turbulentos países hispânicos.

No Brasil, as diretrizes do gabinete Ouro Preto seguiram a tradição imperial e desconsideraram as recomendações de Salvador de Mendonça. Em um ofício reservado a Lafaiete Pereira, expôs a visão do Império acerca da aproximação com os Estados Unidos:

[...] vou declarar a V. Exª . quais são as minhas idéias sobre essas questões e como desejo que elas se resolvam. Os benefícios que podem produzir as associações aduaneiras, tais como a uniformidade das tarifas com a redução dos direitos de entrada e saída de despesas do porto e trânsito, um código comum, a proteção de indústrias e a conformidade nos pesos e medidas, interessam mais particularmente aos países centrais rodeados por nações que disponham de portos e rios navegáveis por onde se fazem a importação e a exportação. [...] não sendo os povos confederados, têm política e aspirações diversas e raramente podem adotar idênticas medidas financeiras. [...] Não descubro conseguintemente, grande conveniência em entrar o Brasil em uma associação aduaneira $[\ldots]^{5}$

A documentação que instruía a delegação brasileira expunha a resistência imperial em relação a uma aproximação aos demais países americanos e aos Estados Unidos, em que a negociação só era vislumbrada em termos específicos, como no caso do querosene e do açúcar (Bueno, 1995, p.119).

A proclamação da República forçou a alteração nas diretrizes da política externa brasileira, atitude justificada em nome da fraternidade republicana e americana. Os representantes do País na Confe-

5 Ofício reservado do visconde de Ouro Preto à chefia da missão brasileira à Conferência Americana, de 15 de julho de 1889 (cf. Azevedo, 1971, p.151-2). 
rência de Washington, que havia se iniciado cerca de um mês antes da mudança do regime, solicitaram instruções ao governo provisório e logo tiveram novo posicionamento para deliberar no certame. Os republicanos no poder desejavam que o novo regime rompesse com as referências políticas que lembrassem o passado monárquico, inaugurando um período de progresso, democracia e distante da herança colonial e na busca por tais objetivos; os dirigentes do campo político brasileiro depararam com uma série de problemas institucionais que se prolongaram na diplomacia.

A proclamação da República, antes que ecoasse no plano externo e fosse buscado seu reconhecimento internacional, demandou uma série de ações por parte dos republicanos, que assumiram o poder no sentido de modificar o funcionamento do aparato político existente, deflagrando um processo nomeado de republicanização. $\mathrm{O}$ decreto de 15 de novembro de 1889 instalava o sistema federativo no país e autorizava as províncias, transformadas em Estados, a eleger suas respectivas assembleias constituintes (Carone, 1969, p.14-6). Na prática, o que se via era a instalação de uma ditadura, pois não havia órgão legislativo funcionando no País depois da dissolução do Parlamento Imperial, o que comprometia a estabilidade interna e externa do País.

Internamente, em relação à recepção da República nos Estados onde o movimento republicano fora atuante, como Minas Gerais, São Paulo, Rio de Janeiro, Rio Grande do Sul e Pernambuco, o que se viu foram soluções heterogêneas, que não conseguiram arrefecer as disputas entre grupos locais. Por indicação dos membros do governo provisório, foram nomeados os presidentes dos Estados: Cesário Alvim ocupou o cargo em Minas Gerais sem protestos, até que conflitos entre republicanos e monarquistas, que insistiam em não deixar os cargos do antigo regime, emergiram, provocando uma cisão que chegou ao governo federal, na busca por apoio de Deodoro, chefe do governo provisório, e do almirante Wandenkolk, ministro da Marinha, que liderava os protestos contra a autoridade do marechal.

Em São Paulo, a República chegou sem protestos organizados contrários ao seu estabelecimento e foi liderada por um partido que possuía tradição organizatória: Prudente de Moraes e Rangel Pestana 
assumiram o governo do Estado de forma conjunta com Campos Sales, que ofereceu aos monarquistas, certamente um foco de instabilidade, participação na vida administrativa, conseguindo adesões e diminuição de problemas. Já no Rio de Janeiro, Francisco Portela foi indicado presidente, governando no epicentro do republicanismo do país, que logo o conduziu para fora do cargo em virtude de disputas sobre a eleição de candidatos aliados a setores majoritários do partido. No Rio Grande do Sul, a situação tornou-se bastante conturbada logo no momento de transição, deflagrando radicalismos e lutas armadas pelo poder, tendo como líder Júlio de Castilhos, que tendia para a constituição de uma República positivista e presidencialista.

Em Pernambuco, os conflitos eram anteriores à mudança do regimee, após a proclamação, ganharam mais força. Liberais (resquícios do partido monárquico) e republicanos passaram a disputar e se alternar no poder até a nomeação do barão de Lucena pelo governo provisório, que ficou no cargo até a saída de Deodoro da Fonseca. Nos demais Estados, a República instalou-se sem problemas graves, mas não anulou querelas que preexistiam (Carone, 1971a, p.18-26).

A falta de unidade do movimento republicano era sentida na prática, pois, se desde seu surgimento era discutido como seria feita a República, ocasionando profundas divergências, agora instalado o novo regime, as lutas pela proeminência política começaram a crescer exponencialmente. $\mathrm{O}$ significado dessas lutas residia na dificuldade de os grupos republicanos convergirem a heterogeneidade ideológica e as brigas individuais em estabilidade política, resultando em um período de incerteza geral. Tanto que o ponto comum das disputas se centrava no principal tópico do republicanismo no País: o federalismo, que não fora absorvido quanto ao seu modo de aplicação à realidade brasileira. Os grupos que imediatamente assumiram o poder não conseguiram oferecer uma resposta "republicana" aos critérios monárquicos de organização do espaço público, ocasionando, por exemplo, divergências acerca da nomeação dos indivíduos que iriam compor a Assembleia Constituinte federal (Lessa, 1988, p.50-1).

Essas características não se restringiam aos Estados, mas estavam unidas ao redor do campo político brasileiro, carente de uma 
ideia homogênea de República, que consequentemente afetava o processo de republicanização do País, que ainda não possuía base constitucional. Com esse objetivo, foi convocada e depois reunida a Assembleia Constituinte um ano após a proclamação da República, convergindo as disputas estaduais em suas deliberações. O período de elaboração da Constituição republicana foi marcado pela intervenção do governo provisório nos assuntos legislativos representados pelos congressistas, que, insistentemente, negavam qualquer tipo de subordinação, fortalecendo o desentendimento e o confronto entre os poderes e grupos, representando interesses regionais, como o caso de São Paulo, que reivindicava maior participação e autonomia de sua vida política desde os tempos do Império e que agora não queria ver tolhidos seus esforços a despeito de querelas entre militares e civis (Monteiro, 1986, p.36-43).

Em 24 de fevereiro de 1891, foi promulgada a primeira Constituição da República brasileira, e, no dia seguinte, Deodoro da Fonseca e Floriano Peixoto foram eleitos presidente e vice-presidente da República, respectivamente, pelo Congresso Constituinte. Floriano Peixoto formava oposição a Deodoro na chapa com Prudente de Morais, candidato derrotado à presidência. Nas Forças Armadas, dissensões internas clarificavam as disputas pelo poder, ao passo que, do lado civil, criticava-se a participação intensa dos militares nas questões políticas. Floriano Peixoto e Deodoro situavam-se em campos opostos na política, mas mostravam que o elemento militar manteria importante papel no governo nos anos seguintes, apesar das hostilidades mútuas (Hahner, 1975, p.53-7). Deodoro não tinha popularidade e havia sido recebido de forma fria pelo Congresso na data de sua posse, ao contrário de Floriano Peixoto. A antipatia vinha desde o governo provisório, quando deliberou medidas centralizadoras que fragmentaram o consenso entre elites e governo, enfurecendo os defensores da autonomia estadual. Dirigentes paulistas chegaram a discutir a separação da federação caso houvesse, no governo, quem tentasse fundar uma República unitária. Os atritos entre paulistas defensores da candidatura de Prudente de Morais e deodoristas cessaram temporariamente após a eleição presidencial, ainda que 
os primeiros saíssem fortalecidos com o apoio dos partidários de Floriano Peixoto.

O imperativo político requisitava a organização institucional e, no campo econômico, a estabilidade da moeda e dos negócios com outros países. No tocante ao segundo aspecto, na tentativa de estimular a industrialização do País, Rui Barbosa, então ministro da Fazenda, adotou uma política de emissão de linhas de crédito, mas logo deparou com o que se convencionou denominar "encilhamento". Sem se preocupar com o lastro da moeda brasileira, o governo provisório viu a inflação crescer e provocar o fechamento de várias empresas, engendrando uma recessão econômica no país conectada com sonegação fiscal e contração de empréstimos para fins diversos do estabelecido pela lei. Ao mesmo tempo, a imprensa estrangeira denunciava a má gestão da economia brasileira, que não conseguiria cumprir os compromissos internacionais caso a ingerência persistisse (Bandeira, 1973, p.133-4). ${ }^{6}$ No campo político, a Constituição de 1891 seria a ferramenta que colocaria em prática ideias existentes desde o Manifesto Republicano de 1870, como o federalismo, a liberdade de culto e de educação e as eleições diretas. Ainda que as divergências não cessassem após sua promulgação, a Constituição previa que a União seria a "fiação" que ligaria as diversas realidades regionais, permitindo a gestão de recursos e políticas de forma independente. E "ao instituir o regime representativo democrático, as leis republicanas abriam - formalmente - a participação no processo político a um grande contingente eleitoral antes marginalizado" (Souza, 1984, p.162-3). Outro ponto que figurava na Constituição era o princípio do arbitramento (capítulo IV, artigo 34, número 11) para as questões controversas ou de disputa com outros países, herança da Primeira Conferência Americana.

6 Em apenas um ano de regime republicano e sob o "encilhamento", apareceram mais empresas no País do que em sete décadas de Império. Segundo Carvalho (1990, p.29-30), a política emissionista estava diretamente ligada com o modo como fora implantada a República: predominavam a (nova) mentalidade predatória e o espírito do capitalismo, sem a ética protestante. 
A efetivação da Constituição deu-se paralelamente à disputa entre os poderes Executivo e Legislativo, que se arrastou por todo o ano de 1891, agravando-se quando a oposição ao presidente da República aprovou uma lei que limitava seus poderes. O contra-ataque veio em forma de golpe. Em 3 de novembro de 1891, Deodoro da Fonseca decretou estado de sítio no País e suspendeu a Constituição. O presidente divulgou longa nota justificando o ato, argumentando que a diminuição das atribuições do Poder Executivo era fruto da ação de grupos radicais que não respeitavam as tradições nacionais e que queriam lhe incutir os traços de tirano sem que ele os possuísse; no âmbito da política externa, Deodoro comentou que a Assembleia Constituinte havia rompido os laços de solidariedade internacional cultivados pelo Brasil com as principais potências da Europa, suprimindo legações em um momento em que o Brasil mais precisava tornar estimadas as novas instituições (Carone, 1969, p.19-21). Vinte dias após o golpe de Deodoro, Floriano Peixoto, articulado com os setores dissidentes do Congresso, acionou o almirante Custódio de Melo, que organizou a Armada no Rio de Janeiro e ameaçou bombardear a cidade caso o presidente não renunciasse. Melo conseguiu a renúncia do presidente, queda imputada pelas dissensões em torno das medidas tangentes à ordem federativa e dificultadas pelo presidente da República no apreço à fortificação da unidade política. Privilegiando minorias em Estados importantes, a política governamental estava fadada ao fracasso, encontrando seu algoz no Congresso. Floriano Peixoto chegava ao poder deparando com as forças militares divididas (ele próprio e Deodoro eram exemplo) e um país institucionalmente desorganizado.

A Constituição de 1891 revelava-se, portanto, incapaz de definir com precisão um "pacto político" suficiente para instituir os novos limites da comunidade política e suas relações internas, pelo menos nos primeiros anos do novo regime, nos quais a incerteza foi elemento dominante (Lessa, 1988, p.66). Baseada claramente no paradigma constitucional norte-americano, a Constituição do Brasil, elaborada em grande medida por Rui Barbosa, revelava a tentativa de vincular o país ao certame continental, americano e republicano, mas trope- 
çava por desconhecer os fundamentos do regime. O Brasil queria romper com tudo que lembrasse o passado monárquico, inclusive no campo econômico, no qual se pretendeu expropriar companhias estrangeiras e expulsar do País o capital europeu. O País passava a se chamar Estados Unidos do Brasil, e a bandeira, em um primeiro momento, era uma clara inspiração na grande República da América do Norte (Bandeira, 1973, p.134). A inspiração dos Estados Unidos como paradigma era dominante no campo político brasileiro, mas não se revelava unânime. Voltava-se para uma americanização da República aliada à ausência de um projeto de política externa (Malatian, 2001, p.116).

Entre a formulação da Constituição e a subida de Floriano Peixoto ao poder no final de 1891, foi discutido e assinado o Tratado de Reciprocidade entre Brasil e Estados Unidos, no qual a interlocução de Salvador de Mendonça com o secretário de Estado norte-americano não deixou de expor as dificuldades internas pelas quais atravessava o Brasil naquele período. Nesse sentido, a articulação entre política interna e externa foi determinante para a formulação de críticas à diplomacia pela opinião pública brasileira, principalmente pela atuação do diplomata, favorável ao acordo com os Estados Unidos.

As primeiras instruções para a formulação de um acordo aduaneiro não ultrapassaram o limite da Conferência que se realizara em Washington. Escolhido como árbitro da Questão das Missões entre Brasil e Argentina, o presidente dos Estados Unidos não poderia assinar convênio que favorecesse o comércio com um dos países reclamantes, ainda mais em um certame em que se discutia tal ação, portanto a ideia de uma "aliança íntima” sugerida por Quintino Bocaiúva não foi levada adiante (Bueno, 1995, p.112). ${ }^{7}$

Contudo, textos de Salvador de Mendonça revelam que novos planos foram discutidos nesse sentido, sendo, inclusive, referendados por James Blaine, secretário de Estado dos Estados Unidos entre 1889 e 1892. Segundo o diplomata, o objetivo era que Brasil e Estados Unidos sondassem os governos do centro e ao sul da América para

7 Para Mendonça (1913, p.168), "não era lícito tornar o juiz em aliado”. 
o fim de se reunirem em uma Segunda Conferência Internacional Americana, que ocorreria no Rio de Janeiro, discutindo sobre o Tratado de Arbitramento, aprovado em 1890, e negociando sua sanção, obtendo um instrumento de regulação das relações entre os povos americanos. Nesse sentido, a maior dificuldade a ser enfrentada era o quesito condizente aos votos de cada país, que não poderiam ter o mesmo número por causa da importância política e econômica exercida individualmente, caso do Brasil e dos Estados Unidos. Para tanto, a União Internacional das Repúblicas Americanas, o bureau de comércio criado após a Conferência de Washington, estabeleceria cotas para cada país de acordo com sua população, favorecendo os norte-americanos, que contavam à época com cerca de cinquenta milhões de habitantes, o que lhes daria onze votos; ao passo que o Brasil, o segundo país mais populoso da América, com aproximadamente quinze milhões, teria apenas quatro votos.

O plano conjunto de Mendonça e Blaine se estendia para a organização de um Tribunal Internacional Americano de natureza permanente e que permitiria a gestão de conflitos entre os países integrantes, garantida a soberania de cada um. As decisões desse Tribunal seriam submetidas a um juizado composto por representantes de três países, que ficariam encarregados de analisar e emitir o parecer sobre as questões (Mendonça, 1913, p.173-9).

Dissertando sobre o assunto, o representante brasileiro parecia encantar-se com a ideia de aliança com os Estados Unidos, colocando o Brasil, ao contrário do que acreditava, exposto a críticas e intervenção norte-americanas, que certamente olhavam a criação de um Tribunal Interamericano com desconfiança, pois ele seria o instrumento que bloquearia suas ações militares ou não no continente. Ele julgava que, caso o Tribunal fosse estabelecido, a Doutrina Monroe poderia ser substituída por um órgão jurídico que impediria o controle norte-americano, tendo como princípios a divisão de responsabilidades e o auxílio interamericano.

O plano era originário das convicções de Salvador de Mendonça, que enxergava o relacionamento com os norte-americanos de forma horizontal e temia que o afastamento da postura de aproximação a 
eles poderia engendrar planos restauradores da Monarquia. O diplomata brasileiro acreditava que, com Blaine à frente da presidência dos Estados Unidos, as chances de o Tribunal se efetivar cresceriam, porém Blaine foi derrotado, jogando por terra seu sonho (ibidem, p.181-5). A perspectiva do diplomata traduzia o entusiasmo dos momentos subsequentes à mudança do regime, percebido na crença em uma fraternidade americana camuflada pelos interesses econômicos dos Estados Unidos e dos políticos do Brasil. Conforme argumenta Clodoaldo Bueno (1995, p.120):

Com a Novel República, a impressão que se tem é de que o governo brasileiro perdeu um pouco de altivez internacional e da consciência da posição do país no concerto internacional. Associava-se o estreitamento de laços comerciais com os Estados Unidos como um dos instrumentos para a consolidação das novas instituições. Esquecia-se que aos olhos da Europa, e mesmo dos Estados Unidos, o que realmente contava era a solidez das instituições políticas aferida pela normalidade político-institucional e pela seriedade na condução das finanças nacionais.

A própria desorganização do Brasil, abalado pela disputa interna nos Estados e na esfera federal, não permitia a formulação de estratégias sólidas em termos de política externa. A diplomacia atuava incisiva e independentemente pelo reconhecimento e respaldo à República no exterior, não possuindo diretrizes quanto ao relacionamento com os Estados Unidos por causa da inexperiência e da falta de planejamento político. Em um cenário de gradativa importância geopolítica norte-americana, tal postura somente contribuía para criar situações que iludiam a diplomacia brasileira, como as percebidas na negociação do tratado bilateral em 1891.

A conversação acerca de um acordo bilateral voltou à baila no final de 1890, quando uma nova lei de tarifas foi aprovada pelo Legislativo dos Estados Unidos, prevendo o estabelecimento de acordos a fim de beneficiar a entrada de produtos estratégicos e de alto consumo, como o café brasileiro. Em carta a Rui Barbosa, ministro da Fazenda, 
de 17 de setembro de 1890, Salvador de Mendonça (cf. Azevedo, 1971, p.153-5) expôs a proposta norte-americana (Bueno, 1995, p.120-2). Para o diplomata, a União (norte-americana) não podia levar vantagem em uma provável guerra de tarifas, pois esse país dependia da importação do produto brasileiro e uma sobretaxação tornaria o produto mais caro, algo nada interessante a seus consumidores. Também recomendava ao ministro que aproveitasse a oportunidade de o Brasil aumentar as exportações do açúcar para aquele mercado, desde que tratados semelhantes não fossem assinados com países exportadores do produto, como a Espanha e a Inglaterra; o primeiro país principalmente, pois possuía colônias diretamente interessadas em acordos que favorecessem a produção açucareira. Mendonça declarava, ainda, que a maior dificuldade com que o país poderia deparar era a mudança na administração norte-americana e uma consequente alteração na lei de tarifas, o que colocaria abaixo os termos de um acordo que favorecesse os produtos brasileiros. A resposta de Rui Barbosa demorou e veio em 20 de outubro de 1890, recomendando que se continuassem as negociações nos termos que Mendonça havia relatado (cf. Azevedo, 1971, p.153).

Bueno (1995, p.121) nota que o representante brasileiro contradizia-se ao fazer tais considerações. Os Estados Unidos já eram o maior mercado do café brasileiro, posição que o acordo não mudaria em termos significativos, o que constituía um ponto frágil em sua argumentação. Quanto à criação de um "monopólio virtual do açúcar brasileiro naquele país" e à ideia de que o intento das colônias espanholas nas Antilhas era a possibilidade de serem incorporadas aos Estados Unidos, o representante brasileiro esquecia-se de que, caso tal fato ocorresse, quebraria tal privilégio.

Mas se, como se deve esperar, o Brasil dentro de poucos anos aumentar a sua produção, graças às condições privilegiadas do seu produto neste mercado, ao ponto de suprir quase toda ou toda a demanda aqui, nenhuma reclamação surgirá, pois o preço do açúcar baixará inevitavelmente. Quem reclamará nesse caso será Cuba por ver perdido seu melhor mercado, e os Estados Unidos esperarão 
pacientemente que as colônias espanholas das Antilhas percam a paciência e se proclamem independentes com o fito de se agregarem à Grande União. Isto está na mente do Governo americano eéa melhor garantia da continuação de um tratado que façamos com esta gente (cf. Azevedo, 1971, p.155).

No mês seguinte, o ministro da Fazenda autorizou a continuação da negociação do acordo, e Salvador de Mendonça continuou a dialogar com Blaine, obtendo do secretário norte-americano a declaração de que o Poder Executivo do País aprovara o estabelecimento do acordo. Em carta ao representante dos Estados Unidos no processo de transação, John Foster, Blaine aprovava o arranjo que o convênio tomaria "em seu conjunto e em detalhe" (cf, Azevedo, 1971, p.155). Salvador de Mendonça foi comunicado imediatamente da resolução de Blaine em 3 de novembro de 1890. Na carta, Blaine comentava que, de acordo com a nova lei de tarifas aprovada pelo Congresso norte-americano, o país deveria buscar a assinatura de acordos de reciprocidade comercial sob pena de sobretaxar os produtos importados. Nesse sentido, Blaine acreditava que o Brasil poderia ser aliado dos Estados Unidos no empreendimento, firmando a troca de produtos importantes para ambas as partes e lhe informando as tarifas a serem cobradas na importação/exportação de outros produtos que entrariam no acordo. Os produtos que poderiam gozar de livre entrada nos Estados Unidos seriam, sumariamente, diversas modalidades de açúcares, café e couros. Por fim, assegurava ao diplomata brasileiro seu entusiasmo com relação a tal acordo, que teria vigência enquanto nenhuma das partes contratantes o denunciasse, ou seja, pedisse sua anulação (ibidem, p.156).

Salvador de Mendonça dirigiu-se, então, ao Brasil para levar as informações do governo dos Estados Unidos e receber instruções quanto aos produtos que estariam incluídos no tratado. Em ofício de 17 de dezembro de 1890, levou ao conhecimento do governo brasileiro que, em virtude da tarifa MacKinley, caso não fosse assinado o acordo, o Brasil teria um ônus de 16,5 milhões de dólares somente entre o café (dois terços do valor) e o açúcar. O representante brasileiro 
também afirmou a Foster, diplomata e negociador norte-americano do acordo, que o Brasil perderia quase 5,5 milhões de libras esterlinas nos termos em que se ajustava o tratado, ao passo que a produção industrial e de manufaturas nos Estados Unidos era mais cara que a europeia para ser exportada. Foster, então, cedeu, apesar de considerar as informações de Salvador de Mendonça exageradas. O Brasil pagaria em taxas alfandegárias a soma de 3.100:000\$, enquanto os Estados Unidos, cerca de 33.000:000\$, ampla vantagem do Brasil que Salvador de Mendonça ancorava na irrevogabilidade da tarifa MacKinley durante os próximos seis anos, ainda que a disputa entre os partidos Democrata e Republicano pelo poder naquele país deixasse os representantes brasileiros temerosos quanto a uma possível revisão dessas taxas. Caso tal receio se concretizasse, o acordo poderia ser denunciado, daí a indefinição no ponto relativo à sua duração. Ele terminava a correspondência recomendando a assinatura do convênio, considerando que tal oportunidade seria a salvação dos Estados brasileiros produtores de açúcar, animando os políticos brasileiros (Mendonça apud Azevedo, 1971, p.157-8; Malatian, 2001, p.115).

A questão para a qual Salvador de Mendonça e o governo brasileiro não atentavam era que, com excesso de otimismo, acreditava-se que a produção de açúcar no Brasil crescesse e conseguisse atender à demanda norte-americana, algo pouco provável em um curto prazo. Bueno (1995, p.122) nota que, na correspondência de Amaral Valente do final de 1890, a impressão "solidária" que Blaine transmitia nas negociações do acordo não era acerca do Brasil em si, mas da importância do produto importado. Tanto que, em visita a diversas cidades dos Estados Unidos, Blaine declarava-se favorável ao protecionismo alfandegário, ao mesmo tempo que elogiava o estabelecimento de tratados de reciprocidade.

De volta aos Estados Unidos, Salvador de Mendonça enviou carta ao ministro da Fazenda, em 2 de janeiro de 1891, requisitando que o ministro acertasse com o governo brasileiro a assinatura e a ratificação do acordo de forma conjunta com os Estados Unidos, para que ele pudesse entrar em vigor simultaneamente nos dois países (cf. 
Azevedo, 1971, p.158-9). Ainda no final do mesmo mês, enviou por meio de cabograma a notícia de que o governo norte-americano já havia sido notificado do aceite do acordo e de suas bases, mas ainda não havia recebido ordens para assiná-lo, advertindo os representantes brasileiros sobre uma possível perda de vantagens caso fosse prorrogado tal ato (ibidem, p.159). Nos dias seguintes, notas oficiais foram trocadas: Tristão de Alencar Araripe havia sucedido Rui Barbosa como ministro da Fazenda e pedia que Salvador de Mendonça assinasse o acordo, conforme havia ajustado com Barbosa (ibidem).

$\mathrm{O}$ acordo foi assinado em 31 de janeiro de 1891 e proclamado pelos governos do Brasil e dos Estados Unidos no dia 5 de fevereiro do mesmo ano. No ato da assinatura do tratado, foram trocadas notas entre Salvador de Mendonça e James Blaine. A carta entregue por Mendonça continha o histórico do processo de negociação do acordo, e "animado pelo espírito de sincera amizade", declarava:

É portanto, motivo de grande satisfação para mim poder comunicar-vos que o Governo dos Estados Unidos do Brasil, como reciprocidade devida, e em atenção à entrada nos portos dos Estados Unidos da América, livre de todo o direito, nacional, de Estado ou municipal, dos artigos enunciados na vossa nota de 3 de novembro de 1890, autorizou, por ato legal, a introdução em todos os portos de entrada do Brasil, a principiar do dia 1ㅇ de abril de 1891, livre de todo o direito, nacional provincial ou municipal, dos artigos ou mercadorias mencionadas na seguinte lista, com a condição de que tais artigos sejam produto ou manufatura dos Estados Unidos da América (cf. Azevedo, 1971, p.160) ${ }^{8}$.

Os produtos que teriam livre entrada no Brasil eram: milho e seus derivados, farinha de trigo, diversos grãos, carnes, ferramentas, instrumentos e máquinas para a agricultura, mineração e mecânica, máquinas para vapor e para indústrias e material para estrada de

8 As notas também estão presentes no relatório do Ministério das Relações Exteriores do Brasil de 1890. 
ferro. Na nota, Salvador de Mendonça esclarecia que o governo brasileiro não faria nenhum aumento na taxa de exportação em vigor sobre os produtos enumerados na nota de 3 de novembro do ano anterior, nem sobre produtos atualmente livres da tarifa norte-americana. Observava que o governo brasileiro reservava-se no direito de adotar leis e regulamentos necessários para proteger suas rendas e impedir fraudes nas declarações vindas dos Estados Unidos, e, por fim, que caso o tratado viesse a ser denunciado por um dos países, deveria ser informado ao outro com três meses de antecipação.

A resposta de Blaine seguia os mesmos termos da nota de Salvador de Mendonça sobre o processo de negociação do tratado. Também comunicava o aceite do presidente dos Estados Unidos, conforme nota de 3 de novembro de 1890 , esclarecendo que a data fixada para entrada livre do açúcar seria o primeiro dia de abril de 1891, e terminava a nota felicitando o diplomata brasileiro por haver prestado valioso serviço (ibidem, p.161-2).

\section{Críticas à aproximação do Brasil com os Estados Unidos}

A assinatura do acordo assinalou a confusão daqueles tempos, notou Moniz Bandeira (1973, p.134). A República brasileira, livre das pressões europeias, rompia com a política externa imperial e aceitava o tratado com os Estados Unidos, que ficou conhecido pelo nome de seus principais articuladores: "Blaine-Mendonça". O acordo não era apenas um marco econômico, mas político, pois representava o entendimento formal entre dois países antes separados por seus regimes e que agora se aproximavam. Nesse processo de "americanização" da política externa e da diplomacia - entendendo o termo como uma guinada e aproximação com o continente americano em termos político-econômicos, especialmente com os Estados Unidos -, as ideias e as práticas dos indivíduos atrelados ao poder político foram duramente criticadas. Na disputa pelo poder entre grupos políticos, temia-se que a vassalagem econômica se estabelecesse em razão da 
carência de apoio institucional do País, e não faltaram certames que elucidassem tal realidade.

No campo político, de onde saíram as deliberações que autorizaram a assinatura do acordo, já existiam divergências. Salvador de Mendonça posicionava-se em busca do estreitamento das relações comerciais e políticas com os Estados Unidos, uma vez que considerava inevitável sua preeminência no continente (Malatian, 2001, p.118). Rui Barbosa, ministro da Fazenda, deixou o cargo em 21 de janeiro de 1891 por não concordar com o processo de negociação do tratado, especialmente com a ausência da cláusula que dava exclusividade à entrada do açúcar de procedência brasileira nos Estados Unidos (Bueno, 1995, p.126-7). ${ }^{9}$

A existência desses desacordos justificava-se pelo fato de ser um convênio inédito na história do País e encarado pelo governo como uma saída para a crise de mercados internacionais do açúcar nordestino (Malatian, 2001). Os temores dos ministros da Fazenda e das Relações Exteriores fizeram-se sentir na correspondência diplomática, quando passaram a negociar Espanha e Estados Unidos. Um acordo semelhante com o país europeu praticamente anularia os esforços de promoção do açúcar brasileiro, que passaria a concorrer com a produção antilhana, mais barata.

Em março de 1891, o barão de Lucena, então ministro da Fazenda, determinou a Salvador de Mendonça que "habilitasse o governo a responder às censuras feitas no País ao tratado", recebendo imediata resposta do representante brasileiro: Mendonça explicava que os Estados Unidos "perderiam" com o acordo sessenta mil contos de réis, ao passo que o Brasil, dez, além das vantagens que teriam o café e o açúcar naquele mercado, e ademais não haveria razões para crer em uma "ofensa" à indústria brasileira, pois, caso acontecesse, o acordo poderia ser denunciado, e as mercadorias contempladas no acordo, importadas da Europa (cf. Azevedo, 1971, p.162). Persistiam os receios acerca das dificuldades que o tratado traria às indústrias nacionais. Em outra correspondência ao ministério das Relações

9 No lugar de Rui Barbosa, ocupou o cargo Tristão de Araripe. 
Exteriores, explicava que se temia a concorrência do setor brasileiro com o europeu e norte-americano, não encontrando razões para tal, pois as casas de exportação dos Estados Unidos ainda não estavam preparadas para exportar mais do que antes, e o Brasil poderia se proteger também pela elevação das tarifas. ${ }^{10}$

Em dois ofícios, Salvador de Mendonça explicava ao ministro os tipos de açúcar que estavam contemplados no acordo e apontava para o favorecimento brasileiro na questão. Mesmo açúcares não contemplados pagariam menos que outros países: o Brasil, 10 réis/ libra, e os demais países, 40 réis/libra. O representante brasileiro também já falava do acordo que possivelmente seria assinado com as colônias espanholas, recomendando expressamente que a suspensão do acordo sem sua experimentação de um ou dois anos traria o rompimento das relações entre os países. ${ }^{11}$

Em maio, os Estados Unidos assinaram o acordo com a Espanha concedendo-lhe também a livre entrada do açúcar (Bueno, 1995, p.127). Salvador de Mendonça enviou justificativa ao governo brasileiro, informando que o presidente norte-americano havia aproveitado a ausência de Blaine, que garantiu ao brasileiro a exclusividade açucareira, para negociar com os espanhóis o dobro das concessões brasileiras. ${ }^{12}$ As críticas de intelectuais na imprensa e de setores de oposição ao governo de Deodoro da Fonseca multiplicaram-se, levando o ministro das Relações Exteriores, Justo Leite Chermont, a pedir, por meio de correspondência oficial, que Salvador de Mendonça se esforçasse para obter a cláusula de exclusividade, caso contrário o acordo seria denunciado. ${ }^{13}$

10 Carta de Salvador de Mendonça ao barão de Lucena, de 10 de março de 1891 (cf. Azevedo, 1971, p.162).

11 Cartas de Salvador de Mendonça ao barão de Lucena, de 14 e 28 março de 1891 (Azevedo, 1971, p.163).

12 Carta de Salvador de Mendonça a Justo Leite Chermont, de 31 maio de 1891 (cf. Azevedo, 1971, p.164).

13 Carta de Justo Leite Chermont a Salvador de Mendonça, de 2 junho de 1891 (cf. Azevedo, 1971, p.164). 
A resposta do representante brasileiro traria um elemento não abordado na correspondência diplomática sobre o convênio comercial até então. Ele referia que o acordo pretendido pelo atual ministério e por ex-ministros da Fazenda estava nas bases de negociação do tratado de aliança que Quintino Bocaiúva havia mandado iniciar em janeiro de 1890, não sendo condição do acordo aduaneiro. ${ }^{14}$ Especificamente, aludia à "aliança íntima" proposta pelo ministro do governo provisório, Quintino Bocaiúva, que chegou a escrever os artigos para o estabelecimento de uma aliança defensiva e ofensiva para a defesa das soberanias e troca de recursos entre os dois países. O respaldo dos Estados Unidos às novas instituições brasileiras, duramente atacadas pela imprensa estrangeira e por grupos monarquistas, era visto como indispensável para assegurá-las, mas deveriam estar subvencionadas às relações comerciais, informava Salvador de Mendonça. ${ }^{15}$

A celeuma intragovernamental foi arrastada até o final de junho de 1891. De um lado, o ministro pressionado pelas críticas argumentava que o negócio da aliança era distinto do acordo aduaneiro e que este havia sido estabelecido com o objetivo de proteger a "indústria sacarina"; de outro, o diplomata brasileiro, que salientava a distinção das negociações e dizia ser improvável a inclusão da cláusula de exclusividade no acordo aduaneiro. ${ }^{16}$ Salvador de Mendonça fazia a defesa do acordo baseando-se nos benefícios políticos que o país poderia obter em curto prazo, pois estava em processo de arbitramento pelo presidente dos Estados Unidos a questão das missões entre Brasil e Argentina. Assim, a denúncia do convênio poderia colocar em risco uma decisão favorável ao País. Ante as pressões do governo, o diplomata reuniu-se com representantes norte-americanos, que, por sua vez, declararam que a lei que serviu de base à negociação obrigava-os a negociar com todos os países produtores de açúcar e café, e a falta

14 Carta de Salvador de Mendonça a J. L. Chermont, de 7 de junho de 1891 (cf. Azevedo, 1971, p.165).

15 Cartas de Salvador de Mendonça a Quintino Bocaiúva, de 7, 8 e 14 de janeiro de 1890. Ver também carta de Quintino Bocaiúva à missão especial em Washington, de 2 de setembro de 1890 (cf. Azevedo, 1971, p.165).

16 Telegramas de 7 e 10 de junho de 1891 (cf. Azevedo, 1971, p.165). 
de apoio ou ratificação pelo Congresso brasileiro ao tratado seria encarada como atitude hostil aos Estados Unidos. ${ }^{17}$ A resposta do governo brasileiro viria no telegrama cifrado alguns dias depois:

Diga verbalmente a Foster Convênio Aduaneiro está ratificado desde sua assinatura, que não depende voto Congresso e está sendo, sempre foi e será executado e cumprido boa-fé e lealmente, Governo brasileiro negociou-o na persuasão Governo americano não faria Convênio idêntico com outra nação, pois nossa intenção era proteger indústria brasileira açúcar, criando para ela um grande mercado privilegiado, assinado Convênio com a Espanha açúcar brasileiro não poderá competir açúcar Cuba, ficando nulo o único favor que nos concede e ficando nosso açúcar no mesmo pé que anteriormente, por conseguinte nada ganhamos Convênio, antes perdermos simpatia todas nações Europa e afeta com dispensa e redução direitos importação e muitos gêneros exportação. ${ }^{18}$

Foi dada continuidade ao acordo, apesar da grita levantada por diversos setores da sociedade brasileira, como o grupo monarquista, que se apropriou do período turbulento e dos atos do novo regime para forjar novos planos de ação. Os monarquistas aproveitavam-se da heterogeneidade de opiniões e faziam apologia à política externa do Império, tanto no aspecto econômico quanto geográfico, na medida em que os republicanos demonstravam estar "entregando" o comando da economia e do território (ver o exemplo das Missões e o arbitramento) aos Estados Unidos (Janotti, 1986, p.24-5; Magnoli, 1997, p.223; Bueno, 1995, p.132).

No certame de crítica política e econômica generalizada, destacou-se o monarquista Eduardo Prado, advogado e jornalista que publicou uma obra atacando diretamente a aproximação do Brasil com

17 Carta de Salvador de Mendonça ao Ministério das Relações Exteriores, de 16 de junho de 1891 (cf. Azevedo, 1971, p.166).

18 Telegrama a Salvador de Mendonça, de 21 de junho de 1891 (cf. Azevedo, 1971, p.166). 
os Estados Unidos, intitulada A ilusão americana. A obra e as ideias de Prado passaram a ser a base ideológica do grupo monarquista, que, na última década do século XIX, acreditava ser possível organizar o movimento de restauração da Monarquia no País (Janotti, 1986, p.34). Eduardo Prado era filho de uma tradicional família paulista e formou-se em Direito na Faculdade de São Paulo, o que o conduziu à crítica política e literária. Esse contato o conduziu à Europa, onde trabalhou como adido da legação brasileira em Londres. A mudança de regime faria Eduardo Prado um ferrenho defensor das instituições imperiais, diametralmente opostas à recente "vassalagem" da República brasileira aos Estados Unidos, ainda que, em um certo sentido, valorizasse as condições físicas e naturais desse país que o conduziram a um alto grau de desenvolvimento material (ibidem, p.80).

O livro A ilusão americana foi publicado em 1893 e significou um forte ataque ao governo provisório e à conturbada presidência do Marechal Deodoro da Fonseca, sucedido por Floriano Peixoto, outro militar não menos autoritário. Se as repúblicas deveriam seguir o aforismo de Montesquieu, tendo como fundamento a virtude, o Brasil não se adequava como um regime republicano legítimo, na medida em que seus dirigentes eram homens do corpo militar e sem conhecimento da política nacional e internacional. O livro de Prado foi confiscado, e muitos exemplares foram destruídos.

O primeiro capítulo da obra revela nitidamente o que significava a reorientação da política externa brasileira para o continente americano. Para Eduardo Prado (1958, p.7-9), a fraternidade americana não existia e era um erro acreditar que os países da América deveriam estar unidos pelo regime político republicano, pois entre eles prevaleceram mais as disputas políticas e os conflitos militares do que demonstrações de amizade. ${ }^{19}$ Nesse contexto, Prado (1958, p.18) se perguntava sobre a intervenção dos Estados Unidos ante as turbulências pelas quais frequentemente passavam os países latino-americanos, especificamente o entendimento da Doutrina Monroe por estes (o Brasil republicano estava incluído), que a enca-

19 Ver também Janotti (1986, p.79). 
ravam como sinônimo de uma aliança definitiva, um compromisso formal que não correspondia à realidade. Eduardo Prado (1958, p.46) não se contentava em fornecer exemplos negativos do comportamento dos países vizinhos como também insistia em argumentos que valorizassem o período imperial, pois, "após setenta anos de liberdade, o grande erro foi cometido em 1889, quando os brasileiros quiseram impor ao Brasil artificialmente a fórmula norte-americana”.

Prado discordava integralmente de Salvador de Mendonça no que tangia à atuação de James Blaine, secretário de Estado norte-americano entre 1889 e 1892, perante o Brasil e a América. Mendonça (1913, p.266) havia escrito que Blaine era o maior estadista que teve a fortuna de conhecer em toda sua vida e possuía relações que iam além dos compromissos oficiosos, sendo o norte-americano como um amigo íntimo do brasileiro. Prado (1958, p.82-7) dizia que, apesar de Blaine ser o último sopro heroico dos tempos da independência norte-americana, ele era incompleto, desequilibrado, faltando-lhe a grandeza moral dos grandes estadistas, demonstrando ser dotado de um temperamento conquistador.

O segundo capítulo foi dedicado ao relacionamento entre Brasil e Estados Unidos, exclusivamente. Historiando as relações entre os países, Prado (1958, p.99-105) disserta sobre o modo frio pelo qual foi acolhida a independência do Brasil pelos norte-americanos até as intrigas surgidas durante o conflito com o Paraguai, quando se postaram a favor de López e reclamaram indenizações utilizando menos o recurso racional do que a violência. Outro ponto que Prado criticava era a luta dos políticos norte-americanos pela livre-navegação no Rio Amazonas durante o Império, que pressionaram pelo ato, mas não investiram de modo significativo na região, ação que coube aos ingleses realizar.

Eduardo Prado não acreditava no sentimentalismo - leia-se crença em amizade incondicional justificada pelo regime político - em termos de política internacional. Julgava-a arrogante e egoística, algo que a diplomacia brasileira não enxergava naquele momento, deixando ser ludibriada pelos interesses dos Estados Unidos. No tocante à economia, investia contra a sede monopolista norte-americana, que 
buscava em outros países os mercados para seus produtos, formulando, para isso, tratados de comércio.

Tratados de comércio! Eis aí a grande ambição norte-americana, ambição que não é propriamente do povo, mas sim da classe plutocrática, do mundo dos monopolizadores que, não contentes com o mercado interno de que eles têm o monopólio contra o estrangeiro [...] que se vê privado do grande benefício que a concorrência universal lhe traria com o forçado abaixamento dos preços (Prado, 1958, p.124).

O monarquista brasileiro acreditava que o real sentido da formulação dos convênios aduaneiros dos Estados Unidos com os países latino-americanos era extorquir deles produtos estratégicos, concedendo-lhes, em troca, vantagens aparentes. $\mathrm{O}$ exemplo mais recente do argumento de Prado era o Tratado de Reciprocidade assinado com o Brasil em 1891, no qual a pseudoexclusividade ao açúcar brasileiro foi concedida. Nesse sentido, Eduardo Prado (1958, p.142-7) voltava a atacar James Blaine, que vinha articulando uma reunião interamericana desde meados da década de 1880 com o objetivo de extrair acordos comerciais ainda que tivesse que utilizar da ideia da fraternidade americana.

O Brasil foi o primeiro país que cedeu aos desejos norte-americanos, negociando e assinando o acordo comercial. $\mathrm{O}$ acordo que previa a isenção dos direitos de importação sobre o café brasileiro e tipos mais "nobres" de açúcar era ilusório, pois o primeiro produto não pagava direitos nos Estados Unidos desde 1872, e o açúcar vindo do Havaí entrava neste país livremente, mas era incapaz de suprir a demanda do mercado, conforme já havia observado Salvador de Mendonça. Para Eduardo Prado (1958, p.151-7), o acordo paralelo dos Estados Unidos com a Espanha e suas colônias produtoras da mercadoria pôs fim aos benefícios que o Brasil tinha no acordo e legitimava a tese do ludibrio norte-americano (Bueno, 1995, p.128). Era um "erro colossal" acreditar que havia tantas simpatias por um Brasil que mudara seu regime havia apenas quatro anos, conside- 
rando o apreço que existia ao imperador Dom Pedro II naquele país, lembrado em alguns discursos no Senado norte-americano.

Outro aspecto que feria a dignidade brasileira na visão de Eduardo Prado era a escassez cerimonial com que eram tratados os representantes brasileiros nos Estados Unidos, muitas vezes expostos ao ridículo na imprensa, como aconteceu com o próprio Salvador de Mendonça em duas ocasiões: quando adquiriu uma coleção de obras de arte e no processo de compra de prata pelo Brasil. No primeiro episódio, considerou-se a coleção falsa, e o representante brasileiro foi ridicularizado por desconhecer sua autenticidade, e, no segundo, a imprensa acusou Mendonça de ter se beneficiado pessoalmente dessa compra. Curiosamente, Prado colocava-se ao lado de Mendonça argumentando que o diplomata não havia recorrido à justiça norte-americana porque "sabia" qual seria sua decisão entre um compatriota e um sul-americano.

As instituições criadas em determinado país não poderiam desenvolver-se em outros, com tradição cultural e política distintas. Os países sul-americanos, e recentemente o Brasil, ao "copiar" as instituições norte-americanas, não calculavam quão funestos poderiam ser os resultados do transplante, pois chegavam maculadas com o signo da corrupção (Prado, 1958, p.161, 170-2). Ao fim da obra, Prado (1958, p.183) justifica, em algumas expressões, o título de sua obra:

Devemos concluir de tudo quanto escrevemos:

Que não há razão para querer o Brasil imitar os Estados Unidos porque sairíamos da nossa índole, e, principalmente porque já estão patentes e lamentáveis, sob os nossos olhos, os tristes resultados da nossa imitação;

Que os pretendidos laços que se diz existirem entre o Brasil e a República americana, são fictícios, pois não temos com aquele país afinidades de natureza real e duradoura;

Que a história da política internacional dos Estados Unidos não demonstra, por parte daquele país benevolência alguma para conosco ou para com qualquer República latino-americana; 
Que todas as vezes que tem o Brasil estado em contato com os Estados Unidos tem tido outras tantas ocasiões para se convencer de que a amizade americana (amizade unilateral e que, aliás, só nós apregoamos) é nula quando não interesseira;

Que a influência moral daquele país, sobre o nosso, tem sido perniciosa.

Para Janotti (1986, p.80), a obra de Eduardo Prado explora três ordens de ideias: o nacionalismo, a crítica à República brasileira e, por último, defende os interesses britânicos, prejudicados com a mudança do regime. Por meio de diversas comparações com o período monárquico, o autor mostra que os governos republicanos passaram sistematicamente a desconsiderar a tradição política, construída até 1889 pelo Império, de altivez e distinção no cenário internacional. A ausência de um planejamento e diretrizes para a política, exterior pelos republicanos no poder também foi notada por Bueno (1995, p.22), na perda da ênfase de dois pontos fundamentais: o controle da política comercial e alfandegária e a pretensão de hegemonia regional. O Tratado de Reciprocidade realçava tal perda, pois os tributos aduaneiros proviam grande parte das rendas para o País e transmitia a imagem de fragilidade aos vizinhos, que chegaram a reclamar acordos semelhantes, sem sucesso. A visão altamente moralista e contraditoriamente nacionalista de Prado entendia que somente a cultura europeia e o capitalismo britânico, símbolos do Segundo Reinado, poderiam "salvar" o Brasil, que vivia sob um oceano de incertezas aproveitado pelos norte-americanos, que utilizaram do epíteto de "padrinhos do batismo político brasileiro" para extrair novos mercados consumidores de seus produtos (Janotti, 1986, p.81).

Representantes de outros países passaram a insistir, por meio de meios oficiais ou pela imprensa, na assinatura de acordos aduaneiros semelhantes ao tratado "Blaine-Mendonça". A Argentina viu-se prejudicada com a livre entrada no Brasil da farinha de trigo norte-americana, pois era grande exportadora do produto ao vizinho. O Chile almejava acordo semelhante para expandir sua produção 
de vinhos, e tanto Portugal quanto a Inglaterra passaram a observar atentamente o desenrolar dos fatos (Bueno, 1995, p.135-6).

Durante os anos de 1891 a 1894, a despeito das críticas e pressões políticas, o acordo foi mantido, e as relações econômicas entre os dois países não sofreram, contudo, profundas alterações, apesar de a escassez estatística impedir a análise precisa da questão. ${ }^{20} \mathrm{O}$ que se pode ler nas declarações dos representantes alfandegários presentes no Relatório do Ministério da Fazenda de 1892 são apenas sugestões de que o acordo estaria prejudicando o comércio, mas recomendava prudência no tratamento dado à questão, pois justamente a falta de dados poderia conduzir a uma atitude inconsequente, ou seja, a denúncia do tratado.

À luz dos dados disponíveis para análise ${ }^{21}$ com relação ao café, percebe-se que, entre 1891 e 1894, a exportação de café para os Estados Unidos não sofreu alteração significativa, passando de 3.884.300 para 4.313.700 sacas. Em 1897, quando o tratado já não estava em vigor, o Brasil exportou 5.302.800 sacas para o mesmo país, demonstrando que a situação do produto não havia se modificado com o tratado. O Relatório do Ministério da Fazenda de 1892 ainda indicava que o comércio entre os dois países apresentava resultados semelhantes nos anos anteriores e durante a vigência do acordo, indicando seu parco valor para a economia brasileira, informação que questionava a defesa de Salvador de Mendonça.

A crise política que levou à renúncia do presidente Deodoro da Fonseca, para além das negociações do Tratado comercial, conduziu Mendonça a agir prontamente em prol das instituições brasileiras nos Estados Unidos. Conforme aponta Janotti (1986, p.48), a preocupação do corpo diplomático nesse período era o advento de um golpe de

20 De acordo com Bueno (1995, p.138-40), a carência estatística foi sentida inclusive no relatório do Ministério da Fazenda de 1890, que reclamava a falta de dados em repartições oficiais necessárias ao andamento do comércio e da agricultura. Em razão do fato, foram criadas seções de estatística comercial para fornecer os dados.

21 Relatório do Ministério da Fazenda de 1892. Disponível em: <http://brazil. crl.edu/bsd/bsd/u1577/000126.html>. Acesso em: 21 maio 2008. 
Estado monarquista, um fantasma que foi comumente aproveitado pelos membros do grupo para desestabilizar o regime republicano. Em meio aos conflitos internos, a imprensa norte-americana passou a denunciar a falta de experiência brasileira com o regime republicano, que parecia converter-se em mais uma República tipicamente sul-americana: instável politicamente e desacreditada perante as potências estrangeiras (Bandeira, 1973, p.141).

A troca de correspondências entre o ministro das Relações Exteriores, Justo Leite Chermont, e Salvador de Mendonça, no período em que irrompeu a crise política, demonstrava o quão hesitante era a postura norte-americana perante a questão. Salvador de Mendonça foi comunicado sobre o golpe no dia 4 de novembro de 1891, em telegrama que narrava os decretos presidenciais, bem como o apoio do Exército e da Armada e a tranquilidade completa nos Estados (cf. Azevedo, 1971, p.240). A despeito do apoio prometido ao governo brasileiro e ante os boatos separatistas no País, o mesmo ministro autorizou o representante brasileiro a desmentir tais informações divulgadas pela imprensa, dizendo-lhe que a restauração era ideia combatida por todos, e antigos monarquistas, como Joaquim Nabuco e Ouro Preto, encontravam-se em liberdade (ibidem, p.241). A notícia de separação de alguns Estados da federação brasileira foi tema de outros telegramas enviados por Chermont a Salvador de Mendonça, que confirmava a calma na Região Sul do país, pedia, mais uma vez, que fosse divulgada nos Estados Unidos a paz no Brasil e desmentia o boato de que os membros do Congresso haviam se refugiado nas legações estrangeiras. Os telegramas ainda informavam que o governo não tinha tomado nenhuma medida violenta (ibidem).

Salvador de Mendonça reuniu-se com Blaine a fim de buscar apoio ao Brasil. Ambos acertaram que, caso houvesse golpe monarquista e o governo legal se refugiasse no interior do país, os Estados Unidos manter-se-iam ao lado deste grupo. O secretário norte-americano aventava em correspondência que seria melhor que tal respaldo se restringisse à correspondência em que tratava do assunto, pois não queria ser acusado de intervir em querelas domésticas do Brasil (Bueno, 1995, p.114). O telegrama do dia 16 de novembro tinha 
por destinatário o presidente norte-americano e expressava a visão brasileira - e deodorista - da questão:

Transmita ao Presidente dos Estados Unidos da América a expressão do reconhecimento do Presidente dos Estados Unidos do Brasil pelo vivo interesse que lhe merecem as novas instituições políticas deste país. A moderação que ele aconselharia está na índole do povo brasileiro, nos sentimentos e na política do seu atual Presidente, e tem sido praticada por seu governo. O Presidente pois vê com grande satisfação que, nesse ponto, como em tantos outros, se acham as duas Repúblicas de perfeito acordo, e pode dizer que o conselho do amigo encontraria acolhimento digno dele. - Chermont (cf. Azevedo, 1971, p.242).

Segundo Bueno (1995, p.115), esse telegrama chegou às mãos do presidente norte-americano somente em 24 de novembro, data em que a crise já havia sido resolvida, e Deodoro, renunciado ao cargo. Mesmo assim, Harrison agradeceu a mensagem, mostrando estar satisfeito com o desfecho pacífico da crise. A preocupação de Salvador de Mendonça com um golpe monarquista estava diretamente ligada às dificuldades internas do país, ainda que a disputa "oficial" se restringisse aos círculos republicanos deodoristas e florianistas. Nessa tônica, em janeiro de 1892, voltou o diplomata a referir-se a boatos de um golpe que poderia perder força caso partisse dos Estados Unidos uma nota monroísta com direção à Europa ou até mesmo uma esquadra dali para o porto da capital federal, ao passo que o governo agradecia a oportunidade no dia seguinte. ${ }^{22}$

A negociação do acordo comercial e a consequente aproximação com os Estados Unidos foram processos definidores da política interna e externa do Brasil, que atravessava uma crise de poder propensa a gestar uma reviravolta abrupta do cenário político, avolumando os problemas já existentes. A gestão de Salvador de Mendonça em Wa-

22 Carta de Mendonça a F. L. Leite Pereira, de 11, 12 e 18 de janeiro de 1892 (cf. Azevedo, 1971, p.242). 
shington foi decisiva nesse sentido, pois revelou o modus operandi do governo brasileiro no cenário internacional, ainda que inexperiente e pouco altivo, conforme expressão de Clodoaldo Bueno (1995, p.120).

Os sintomas de uma reorientação da política exterior do Brasil, inaugurados na Conferência Internacional Americana em 1889-1890, foram aperfeiçoados com o acordo "Blaine-Mendonça", mas duramente criticados pelo sentido que tal aproximação foi conduzida.

O constante temor dos republicanos a um golpe restaurador imprimia a ideia de que o regime ainda não se firmara, ou seja, era frágil, e foi justamente nesse ponto que Salvador de Mendonça explorou o contato com James Blaine e o Poder Executivo dos Estados Unidos. Ele tinha em Blaine - e naturalmente no governo dos Estados Unidos - a noção de ser um aliado extracomercial e garantidor das instituições republicanas (ibidem, p.117, 147). Essa manifestação na correspondência diplomática exprimia o grau de influência e poder que eles passavam a ter no continente e seus contornos econômicos, vistos pelo Brasil, frágil, como apoio político. Essa visão invertida contribuiu para a proliferação das críticas de monarquistas e republicanos ao regime.

A busca por uma identidade americana associada ao republicanismo, mesmo atacada por indivíduos como Eduardo Prado, também foi ideia recorrente, manifesta no acordo comercial que representava a inoculação de um antídoto contra o monarquismo. Mas a ideia possuía o contraponto da instabilidade interna, algo intensamente explorado no setor externo, pela busca pelo novo porém tradicional apoio norte-americano.

Duas décadas mais tarde, escrevia Salvador de Mendonça sobre o período. O diplomata, já aposentado, atribuía a uma "cegueira de patriotismo" os interesses contrários ao estabelecimento do acordo comercial em uma época em que o país se reconstituía política e economicamente. Não acreditava no protecionismo como diretriz econômica, pois era o obstáculo natural ao bom andamento do jogo político, algo que não poderia ter lugar em momento tão decisivo para a República brasileira. Defendeu de forma veemente o acordo argumentando pela via política, na qual o Brasil dependia do arbitramento 
da questão das missões e pela via econômica, na qual a maior prova do benefício brasileiro foi a denúncia do acordo pelos norte-americanos em 28 de agosto de 1894 (cf. Mendonça, 1913, p.187-97).

A comunicação entre o governo norte-americano e o brasileiro, por meio de Salvador de Mendonça, não cessou, apesar das críticas ao acordo, e, ao contrário, intensificou-se pelos anos de 1893 e 1894, quando um novo incidente no Brasil fez o governo de Floriano Peixoto acionar o diplomata nos Estados Unidos, objeto da discussão do terceiro e último capítulo. 



\section{3 \\ A CONSOLIDAÇÃo dA RePÚBLICA}

\section{A crise política e a Revolta da Armada (1893-1894)}

"A gangorra do poder oligárquico começa a funcionar sem os 'princípios' da monarquia” (Cardoso, 1997, p.42). Essa frase é atinente à primeira mudança de governo do Brasil sob o regime republicano e revela, a despeito de sua aparente simplicidade, a síntese dos problemas políticos brasileiros no período. O que ela traduz é a extrema dificuldade de os homens do campo político brasileiro encontrarem respostas institucionais para a organização dos poderes e do funcionamento da própria federação. A disputa pelo poder entre os diversos ramos civis e militares embaralhava o repertório de ideias e ações na política interna ou na política externa, provocando lutas no Parlamento e nas negociações diplomáticas, e as que envolviam a força, tornando rico e complexo o estudo dos anos subsequentes a 1889. As lutas que tornaram o período paradigmático nesse sentido foram as chamadas Revolução Federalista (1893-1895) e a Revolta da Armada (1893-1894). No presente capítulo, as reflexões estarão voltadas para o segundo, ainda que na Região Sul do Brasil o conflito entre republicanos, apoiados por Floriano Peixoto, e os federalistas, liderados por Silveira Martins, não estivesse desconectado ao todo 
do movimento rebelde na capital federal. Tal interesse pela Revolta de parte da Marinha brasileira justifica-se pela dimensão internacional que o conflito assumiu, sendo alvo de algumas intervenções estrangeiras com o fito de mediar e resolver as proposições em debate.

Foi justamente nesse período de transição entre o breve governo de Deodoro da Fonseca e a elevação de Floriano Peixoto ao poder que a diplomacia brasileira nos Estados Unidos trabalhou em duas esferas: no plano interno pela manutenção da República, colocada em perigo seja por excesso de temores republicanos, seja por supervalorização da organização dos monarquistas, e no plano externo, utilizando a recente aliança política e econômica com os norte-americanos para aprimorar a esfera de ação regional do País. Considerando a escassa "experiência institucional" do Brasil no sistema internacional de países ${ }^{1}$ como uma República, a utilização da diplomacia como instrumento de diálogo com países mais "fortes" foi regra geral, como se pôde observar até aqui. Salvador de Mendonça adequou-se às peculiaridades do período para trabalhar em prol da legalidade do governo florianista, ao passo que suas ações reverberaram em inúmeras críticas e contestações, possivelmente influindo na sua saída do cargo em 1898.

As ações da diplomacia em processo de "americanização" não se iniciaram em 1893, mas em 1889, a partir do momento em que um novo referencial político (contemplando regime, constituição, organização interna etc.) foi adotado. A posição francamente pró-americana na Conferência Interamericana e na assinatura do acordo bilateral representou o sintoma de um período carente de aparelhamento institucional, e estas revelaram a falta de homogeneidade na formulação de ações consistentes da política externa brasileira, decorrendo daí as críticas de indivíduos como Eduardo

1 O sistema internacional é o terreno constituído pelos Estados do mundo em função de suas condições políticas, econômicas e militares. Decorre do grau de "evolução" e força desses campos a hierarquia entre os Estados, bem como a anarquia ou equilíbrio das relações entre eles, formulando ações coletivas ou individuais, de paz ou de guerra. Especificamente no campo das relações internacionais, o termo possui diversas acepções (cf. Bobbio et al., 2007, p.1090-2). 
Prado. ${ }^{2}$ As características do cenário político brasileiro somadas à configuração do cenário continental e global no final do século XIX permitem afirmar que a política interna do país - turbulenta - ecoava diretamente nas ações de política externa, daí as intervenções no conflito "doméstico" do Brasil.

Em meio à crise do encilhamento e do golpe frustrado de Deodoro da Fonseca, Floriano Peixoto conseguiu a façanha de obter apoio dos civis republicanos, que, unidos, formularam e fortaleceram a ideia de um "inimigo externo" a eles: o movimento monarquista, ${ }^{3}$ desejoso em restaurar o regime deposto em 1889. Essa aproximação entre as elites civis republicanas e os militares representou, segundo Renato Lessa (1988, p.75), uma importante inovação na história republicana do país:

Trata-se da organização em 1893 do primeiro partido político, de caráter nacional, após a dissolução dos partidos monárquicos. Passados quatro anos de entropia republicana, os novos tempos pareciam encaminhar de modo prático uma das variáveis cruciais para a institucionalização do regime: a definição dos critérios e dos procedimentos de geração de atores políticos coletivos, fora das erráticas combinações parlamentares e conspiratórias.

Dirigido por Francisco Glicério, o Partido Republicano Federal sintetizava não somente um apoio consciente dos segmentos de elites paulistas ao governo federal naquele momento, mas também uma ação dirigida em prol do futuro da República, visando à composição de um Parlamento que lhes fosse favorável quantitativamente e à eleição de um presidente associado ao grupo, fatos que provavel-

2 Para a discussão das ideias de Eduardo Prado sobre a aproximação com os Estados Unidos, ver Capítulo 2.

3 Os monarquistas chegaram a se aproximar de segmentos militares descontentes com o regime republicano. O interesse dos monarquistas era aproveitar as ocasiões de que dispunham para se aliar e perturbar o governo de Floriano Peixoto, como ocorreu na Revolução Federalista. 
mente colocariam termo nas dificuldades de rotinização do regime (Cardoso, 1997, p.43).

Antes desse ato inovador, Floriano Peixoto havia assumido, no final de 1891, um país abalado por uma grave crise econômica e por um golpe político que expunha a falta de limites entre os poderes do presidente e do Congresso nacional. As primeiras atitudes de Floriano Peixoto foram diametralmente opostas às de Deodoro, que se apoiava nos governadores estaduais e encontrava oposição do Legislativo nacional. Como presidente em exercício, ele destituiu todos os governadores que haviam apoiado o golpe de 3 de novembro de 1891 (a única exceção foi o representante do Pará, Lauro Sodré), e para tanto contou com forte apoio do Congresso.

Essa política intervencionista de Floriano Peixoto provocou os partidários de Deodoro da Fonseca, que desejavam retornar ao poder procurando criar um clima de reprovação às ações do Poder Executivo por meio da imprensa e em conferências públicas. Esse grupo, majoritariamente composto por militares, publicou em março de 1892 uma carta-manifesto que gerou uma enérgica reação de Floriano Peixoto. Assinada por treze generais, o documento argumentava que a desorganização em que se encontravam os Estados por causa da ação interventiva do governo federal, que havia permitido o uso da força armada na contenção de movimentos contrários às destituições de governadores, não poderia continuar.

A permanência desse estado de coisas, segundo a carta (cf. Carone, 1969, p.25-6), poderia converter "a obra de 15 de novembro na mais completa anarquia” e solicitava, sem pressão da força armada, que se fizesse respeitar a Constituição Federal e a Lei Eleitoral, convocando novas eleições à presidência da República. $\mathrm{O}$ argumento jurídico em que os generais se baseavam era o artigo número $42 \mathrm{da}$ Constituição Federal de 1891: "no caso de vaga, por qualquer causa, da Presidência ou Vice-Presidência, não houverem ainda decorrido dois anos do período presidencial, proceder-se-á nova eleição”. Aí Floriano Peixoto fez valer o apoio do Congresso, que apoiou sua permanência no cargo e aprovou a aposentadoria compulsória dos envolvidos no incidente. Concomitantemente, demonstrações em 
homenagem a Deodoro, também em 1892, seguidas de uma frustrada tentativa de deposição de Floriano Peixoto, fizeram-no agir duramente: declarou Estado de sítio no país e mandou prender os agitadores da manobra política ou transferiu-os para postos distantes, como no Estado do Amazonas.

No início de 1893, as atenções se voltaram para o Rio Grande do Sul, tradicional foco de conflitos desde a época imperial. O Estado mais meridional do País viu tornarem-se agudos os conflitos entre o governador deposto Júlio de Castilhos, pró-Deodoro, e Silveira Martins, seu adversário, monarquista e organizador do partido denominado Federalista. As forças militares federais se dividiam quanto ao apoio aos líderes do conflito, fato que forçou a ação de Floriano Peixoto, que passou da neutralidade em face da disputa regional para o apoio a Castilhos, que havia apoiado a publicação da carta - manifesto dos treze generais. No início de 1893, Castilhos retornou ao posto de governador do Rio Grande do Sul com o fito de conter a violência e os distúrbios provocados pela luta entre seus partidários e os federalistas de Martins. Em fevereiro, os federalistas iniciaram uma ofensiva em grande parte do Estado, levando a imprensa e os partidários de Castilhos a desfraldar as bandeiras da restauração e do separatismo ao grupo, fatos que logo ganharam importância nacional. Era o início do que a historiografia sobre o período denominou de "Revolução Federalista" (Hahner, 1975, p.68-70; Carone, 1971a, p.95).

O agravamento do conflito no sul, ao longo de 1893, pedia não somente reforços militares por parte do governo federal, mas também reforços orçamentários, que tiveram a sua aprovação dificultada pela oposição minoritária no Congresso e por alguns ministros, entre eles, José Custódio de Melo, que em 1891 havia liderado a ameaça de bombardeio ao Rio de Janeiro com a esquadra nacional caso Deodoro não renunciasse. Custódio de Melo renunciou ao cargo em 30 de abril de 1893, interpretando os atos de Floriano Peixoto como uma fonte de infortúnios à República (Hahner, 1975, p.72).

A posição de Melo traduzia a permanente confusão no cenário político brasileiro, sustentada por uma larga clivagem dos atores 
históricos: batiam-se militares contra civis e membros da Marinha contra membros do Exército. ${ }^{4}$ A primeira dessas "duplas" encenava o debate pela responsabilidade na condução dos negócios do País, remontando à discussão sobre o papel dos militares na política $e$ à convivência - complexa - com os civis. A segunda ancorava-se substancialmente na formação social dos agrupamentos, sendo a Marinha um reduto dos filhos da aristocracia, e o Exército, um contingente composto por indivíduos de origem mais humilde. Consequentemente, a indefinição dos procedimentos do governo federal não permitia a formulação de uma identidade política que sustentasse ou que lhe desse segurança, agravando ou engendrando mais conflitos.

Ao longo de 1893, especulava-se que Floriano Peixoto não convocaria eleições - conforme requisitava a lei eleitoral - para o mandato seguinte, sendo inclusive um dos motivos pelo qual Custódio de Melo deixou o cargo de ministro, pois pretendia se candidatar e substituir Floriano Peixoto. A proclamação havia sido obra do Exército, que não soube lidar com as contingências e a queda de Deodoro, obra da Marinha, que indiretamente exercia pressão sobre Melo para que, com a saída de Floriano Peixoto, completasse a obra "lapidadora" do campo político brasileiro (Carone, 1971a, p.97).

Nesse sentido, no dia 6 de setembro de 1893, Melo divulgou uma carta que expunha suas ideias acerca do governo de Floriano Peixoto. Anunciava que em 1891, quando se rebelara e exigira a saída de Deodoro, seu fito era restaurar o regime constitucional e impedir que a nação se mantivesse submissa e sem protestos ao golpe de estado. No momento em que passou a compor o ministério de Floriano Peixoto até sua saída, Melo dizia em sua carta que acreditava que havia trabalhado "exclusivamente em prol das liberdades populares e contra a ação invasora de uma forma de administração que pretendia anular todas as regalias constitucionais". No entanto, o chefe do Poder Executivo havia mobilizado e colocado em guerra o Sul do Brasil, promovendo gastos do tesouro nacional sem autorização - o

4 Envolviam-se os principais oficiais das respectivas corporações. 
que conduziria o País à falência. Por fim, defendia a ideia de que, como oficial da Marinha e cidadão brasileiro, não poderia postar-se de modo indiferente a tais situações e que combateria, mais uma vez, por meio da ação revolucionária pelo regime da lei, da ordem e da paz. ${ }^{5}$ A publicação de sua carta era feita paralelamente a um fato semelhante ocorrido em novembro de 1891: a tomada de embarcações oficiais na Baía de Guanabara, na capital federal, fazendo a mesma ameaça de antes: a deposição de Floriano Peixoto ou o bombardeio da cidade.

A Revolta da Armada era mais uma pulsação de um regime que carecia de sustentação política, tendo no programa dos revoltosos, em parte exposto na declaração de Custódio de Melo, as diversas questões de ordem interna e externa decorrentes do advento da República. Surge desse conflito uma questão que é relevante para o entendimento da atuação da diplomacia brasileira no período: a participação dos monarquistas no certame por meio de ideias ou de membros inseridos entre os rebeldes. A questão permeia os discursos e a ação da diplomacia entre setembro de 1893 e março de 1894 , período em que os rebeldes mantêm o movimento e define-se como o grande temor de um Estado fragilizado por disputas internas entre grupos sociais.

Como notadamente apresenta José Miguel Arias Neto (2006), muito se fez por meio da imprensa e da historiografia do final do século XIX até o início do século XX para que o conflito adquirisse a pecha monarquista. Certamente temeroso de que as disputas internas entre facções republicanas fragilizassem ainda mais seu governo, Floriano Peixoto e os adeptos de sua política foram os primeiros a disseminar a presença de monarquistas no conflito, muitas vezes superestimando sua intervenção, algo reproduzido de forma acrítica posteriormente, solidificando a visão "construída" da Revolta da Armada (Arias Neto, 2006, p.161-3).

5 Proclamação do contra-almirante Custódio José de Melo, em 6 de setembro de 1893 (cf. Carone, 1969, p.26-8). 
Os monarquistas participaram do conflito, segundo Edgard Carone (1971a, p.102-3), auxiliando financeiramente os rebeldes, tendo na figura de Eduardo Prado o representante do movimento no exterior com a função de arrecadar recursos. Apesar de não mobilizar forças humanas para combater no conflito, os monarquistas se aproveitaram da turbulência para serem ouvidos e, nesse aspecto, conseguiram certa visibilidade por meio da ação do governo, que também fortaleceu sua inserção no certame. Esse fato foi fundamental na interpretação que os estrangeiros tiveram e se aproveitaram para agir, como no caso norte-americano, perceptível na documentação correspondente a Salvador de Mendonça, além da ação do movimento jacobino no plano interno, notoriamente antimonarquista.

O conflito interpretado pelo prisma político possui facetas complementares. No Brasil e no exterior, a participação direta ou indireta de potências estrangeiras europeias e dos Estados Unidos mostrou-se fundamental na condução das negociações e nos rumos que a Revolta tomou. $\mathrm{O}$ interesse internacional pode ser atribuído à grande importância que o local em que era travada a luta possuía. Situado na Baía de Guanabara, o porto do Rio de Janeiro era o centro aglutinador e distribuidor das mercadorias importadas e exportadas pelo País, e a paralisação de suas atividades implicava prejuízos para o Brasil, que dependia dos tributos cobrados sobre as mercadorias vindas do exterior e para os países exportadores, que não podiam entregar seus produtos e receber o pagamento respectivo. Como consequência, Floriano Peixoto viu-se fortalecido pelo apoio do grupo dominante economicamente. Os paulistas, por meio do Congresso e em ações particulares, se posicionaram a favor do Poder Executivo e chegaram a organizar comícios populares e batalhões patrióticos em prol da ação governamental, os quais ocorreram na capital federal e em São Paulo (ibidem, p.107-8).

A primeira ação do governo de Floriano Peixoto foi comunicar seus representantes no exterior sobre a revolta e, no País, reunir-se com os membros de legações estrangeiras com embarcações na Baía de Guanabara, a fim de notificar os responsáveis da dificuldade que teria o governo do Brasil em se responsabilizar pelo que viesse a ocor- 
rer naquelas águas. ${ }^{6} \mathrm{Já}$ no dia 10 de setembro, foi decretado estado de sítio na capital e em Niterói, ao passo que a imprensa internacional noticiava a revolta e aventava a possibilidade de fragmentação do território nacional. Tal argumento colocava o Brasil na mesma condição dos países americanos de origem hispânica, um temor herdado do Segundo Reinado e não dissipado mesmo com a mudança de regime. É importante lembrar que a referência geográfica, política e, em um certo sentido, social devia-se majoritariamente aos Estados Unidos, não à Argentina, ao Uruguai e ao Chile, que possuíam representantes e embarcações na capital, mas, como se verá adiante, foram excluídos de toda participação nas negociações e intervenções efetuadas durante o conflito, corroborando esse afastamento.

A posição estratégica de Salvador de Mendonça logo exigiu que agisse em relação ao problema. Sua ação, ao longo do conflito, desdobrou-se em três focos principais: na compra e organização de uma esquadra para contrapor-se à revoltada, na propaganda por meio de artigos e entrevistas na imprensa - nos Estados Unidos -, em defesa da República brasileira, e junto ao Departamento de Estado norte-americano, especificamente com o secretário Walter Gresham, com a finalidade de sustentar o já propalado "apoio moral" ao Brasil (Bueno, 1995, p.169).

A organização da Esquadra foi severamente criticada por contemporâneos, pois era composta por mercenários e "material imprestável", fortalecendo a ideia de que a intervenção dos Estados Unidos, que se verá adiante, fora decisiva na dissolução do conflito. Conforme apontamento de Arias Neto (2006, p.133), a Revolta chegou a adquirir uma "particularidade jocosa" por meio da opinião pública. Fora tratada como movimento monarquista pelos republicanos, o que figurava mais um evento que comportava saudosismo e anacronismo do que algo "relevante".

6 Discussão exemplar sobre tal atitude de Coelho Neto será desenvolvida no segundo subitem deste capítulo, que irá expor o debate entre Joaquim Nabuco e Felisbelo Freire, contrário à ação e a favor dela governamental, respectivamente. 
A organização e o envio das embarcações dos Estados Unidos ao Brasil estão presentes em grande parte da correspondência diplomática ${ }^{7}$ trocada entre o Ministério das Relações Exteriores e Salvador de Mendonça no período. Nos cabogramas de 27 e 29 de setembro de 1893, após o governo brasileiro requisitar a compra de uma torpedeira, Mendonça informava que o governo norte-americano não poderia vender embarcação desse tipo, pois as disponíveis se encontravam em uso e qualquer transação efetuada deveria ser previamente aprovada pelo Poder Legislativo daquele país, o que atrasaria as ações do governo brasileiro. Paralelamente, foram feitos contatos com o governo do Chile e da Argentina, que também não puderam fornecer embarcações ao Brasil. Os argentinos, especificamente, justificaram sua atitude temendo que uma provável vitória rebelde provocasse uma guerra "injustificável”, ameaçando a paz na América do Sul. ${ }^{8}$

Impelido pelas circunstâncias, Salvador ganhou do secretário de Estado norte-americano a afirmação de que colocaria os navios norte-americanos ao lado dos brasileiros, ao mesmo tempo que o diplomata havia iniciado as negociações para adquirir as embarcações por meios particulares. Gresham afirmou também que "[...] as principais nações europeias estavam prontas a cooperar com ele em uma intervenção que poria termo à revolta [...]" e pediu ao diplomata que lhe listasse os navios rebeldes e os navios de guerra estrangeiros presentes na baía. Na reunião entre Walter Gresham e Salvador de Mendonça, este ainda aproveitou para colocar o norte-americano em posição díspar em relação aos países europeus, considerando que "[...] as nações da Europa, representadas por forças superiores à dos Estados Unidos, bem podiam influir para que a solução do

7 Além da correspondência diplomática "comum" - cabogramas, telegramas e cartas -, especificamente no período da Revolta da Armada há um longo ofício confidencial redigido por Salvador de Mendonça, em que narra os fatos por ele executados entre setembro de 1893 e março de 1894 e em grande parte utilizado aqui.

8 Cabogramas de 27 e 29 de setembro 1893 entre Salvador de Mendonça e o Ministério das Relações Exteriores (cf. Azevedo, 1971, p.244; Bueno, 1995, p.166). 
conflito fosse, em vez da manutenção da República, uma restauração monárquica”. O norte-americano revelou que o presidente Grover Cleveland vinha acompanhando o desenrolar do conflito no Brasil com atenção, chegando a sugerir uma intervenção antecipada aos europeus, que "[...] diziam desejar apenas o restabelecimento da ordem e da paz no Brasil” (Mendonça apud Azevedo, 1971, p.270).

O diálogo entre o representante brasileiro e o norte-americano revelava a aplicação da Doutrina Monroe no relacionamento entre os dois países. A proteção dos Estados Unidos ante uma possível ingerência europeia na política interna do Brasil e o acompanhamento da questão pelo presidente norte-americano expunham o quão imediato seria o posicionamento norte-americano.

As primeiras atitudes do secretariado de Estado norte-americano foram bastante simpáticas ao governo de Floriano Peixoto e deveram-se principalmente à influência que Salvador de Mendonça possuía perante os membros do campo político daquele país. O diplomata brasileiro, preocupado com o destino das instituições republicanas em razão da gravidade da querela interna no Brasil, chegou a sugerir em setembro de 1893 a intervenção direta norte-americana, dada a dificuldade em adquirir e organizar uma nova esquadra. Seu cabograma não foi respondido pelo governo brasileiro, levando-o a investir na compra do material já requerido: munição, armas, embarcações. A posição de Salvador de Mendonça o colocava em um campo passível de críticas, sobretudo dos monarquistas e de alguns segmentos republicanos que defendiam a não intervenção estrangeira em um problema interno. Nesse sentido, sua sugestão - pela participação norte-americana de forma direta na revolta - poderia ser interpretada como uma agressão à soberania nacional. ${ }^{9} \mathrm{O}$ diplomata voltou a perguntar sobre um possível auxílio norte-americano em detrimento do europeu no início de outubro:

9 O conceito de soberania segundo Bobbio et al. (2007, p.1179-88) revela que ela é inalienável e imprescritível, ao contrário da propriedade privada, pois o poder político ao qual está vinculada é uma função pública e, consequentemente, indisponível. Nesse sentido, a soberania busca o interesse geral, não o particular. 
Gresham [Secretário de Estado norte-americano], porém pronto não só dar-vos apoio moral como empregar força conjuntamente com navios europeus contra rebeldes. Intervenção europeia faria talvez perigar República, mas iniciativa americana elimina perigo. Se aceitais mandai-me urgência nomes navios rebeldes e navios de guerra europeus no porto - Mendonça. ${ }^{10}$

A ação de Salvador de Mendonça voltava-se concretamente para a defesa do Brasil republicano contra os interesses monarquistas, identificados como europeus. A proximidade e simpatia recente aos Estados Unidos fariam deste país a grande referência não só para a diplomacia brasileira ali alocada, mas para o governo brasileiro, cioso das ações europeias. Em diversas ocasiões, o diplomata brasileiro associava a presença norte-americana nos assuntos internos brasileiros como um sinal de garantia das instituições republicanas e afastamento de movimentos monarquistas, daí a iniciativa americana em "eliminar o perigo" em uma eventual intervenção. Algumas das críticas ao diplomata brasileiro pela historiografia sobre o período incidem sobre sua forte concentração de interesses nos Estados Unidos, parecendo esquecer o quão importantes eram as relações comerciais e financeiras com os países europeus como a Inglaterra e a Alemanha. A simples contraposição de interesses políticos somente atravancava o relacionamento econômico do Brasil com os demais países (Rodrigues \& Seitenfus, 1995, p.209-10).

Nesse sentido, a primeira e efetiva intervenção estrangeira na Revolta se deu três dias depois da nota de Salvador de Mendonça, quando foi assinado um acordo que, segundo Clodoaldo Bueno (1984), firmou um modus vivendi para o conflito. A negociação que antecedeu a intervenção se deu graças ao agravamento das tensões entre governo e rebeldes, levando os representantes estrangeiros, estes exclusivamente europeus, a se reunir com o fito de proteger seus respectivos cidadãos residentes no Rio de Janeiro, ainda que para tal

10 Cabograma de Salvador de Mendonça a João Felipe Pereira, ministro das Relações Exteriores, de 2 outubro de 1893 (cf. Azevedo, 1971, p.246). 
ação fosse necessário o desembarque de uma "brigada internacional", que poderia conter as hostilidades e impedir o bombardeio da capital do País. Tal postura foi severamente criticada pelo governo e pela Marinha rebelde. Floriano Peixoto disse que receberia "à bala" os estrangeiros que tentassem invadir a capital, atitude semelhante à de Custódio de Melo (Bueno, 1984, p.46).

Oriundo desse conjunto de fatores, nasceu o acordo de 5 de outubro entre os rebeldes e o governo, sendo negociado pelas representações europeias (Inglaterra, França, Itália e Portugal) e pelos Estados Unidos. Ele previa que os representantes estrangeiros poderiam proteger as propriedades de suas respectivas nacionalidades no caso do agravamento das lutas, e as partes em conflito não fomentariam hostilidades, regulamentando os períodos de ataque, ao passo que caberia aos mesmos representantes estrangeiros fazer a intermediação entre ambos. Mais uma vez, assistia-se a uma violação da soberania do país, pois tal ação demonstrava suficientemente que o tratamento dado pelas diplomacias europeia e norte-americana ao conflito se aproximava dos atos praticados em países africanos e asiáticos, ao que se acresce o fato de que outros diplomatas presentes à época do conflito não terem sido sequer consultados acerca de tal ação como os sul-americanos (Argentina, Chile, Paraguai e Uruguai). Paradoxalmente, o governo brasileiro elogiou a postura estrangeira, agradecendo em nota a cooperação em prol da resolução do conflito (ibidem, p.36-8).

Com a assinatura do acordo no início de outubro, o governo federal aproveitou-se da ocasião para rearmar a Baía de Guanabara e finalizar a compra da Esquadra Legal, feita majoritariamente nos Estados Unidos. Em telegrama de 17 de outubro, Salvador de Mendonça relatou o que conseguira comprar no pouco tempo de trabalho: destróieres, torpedeiras e munição, além da tripulação, já contratada. Também fora requisitado novo empréstimo para a empreitada. No mesmo despacho, dizia ainda que

Gresham hoje declarou-se satisfeito ante atitude enérgica [do] nosso governo relativa [à] não intervenção. Mandará instruções [a] 
Thompson e, se Cleveland aprovar, mandará declarar por Ministros Europa que qualquer intervenção armada nos nossos negócios será por este governo reputada [como] violação da Doutrina Monroe. Amanhã telegrafarei decisão. Herald continua publicar notícias falsas fornecidas. Inspiro respostas Times, World, Sun defesa Governo. ${ }^{11}$

A tática do diplomata brasileiro era bastante nítida: respaldado na Doutrina Monroe, com contornos ideológicos definidos e capaz de recorrer militarmente aos Estados Unidos em caso de urgência, o Brasil poderia garantir o apoio americano e republicano ao governo de Floriano Peixoto. A resposta de Gresham quanto à declaração de Salvador de Mendonça veio no mesmo dia: Cleveland julgava prematura qualquer declaração antes de qualquer intento interventor e, em caso afirmativo, procederia de forma "enérgica e direta" para com as nações europeias.

O apoio "moral" dos Estados Unidos ao governo de Floriano Peixoto foi abertamente declarado nos meses iniciais do conflito. O intermediador direto desse relacionamento, Salvador de Mendonça, atribuía tal postura à recente aproximação dos dois países na Conferência Interamericana e no polêmico acordo comercial de 1891. Se, por um lado, a facilidade com que tutelava os interesses do Brasil perante os norte-americanos era positiva a um governo frágil e ditatorial, por outro, causava-lhe problemas no Itamaraty, onde pediam sua exoneração acusando-o de monarquista, em razão do bom relacionamento que possuía com o ex-conselheiro Lafaiete Pereira e com o contra-almirante Saldanha da Gama desde o período do Império (Mendonça, 1913, p.201).

Apesar das acusações, Salvador de Mendonça reiterava seu voto ao governo legal no final de cada correspondência. Tal atitude de republicanismo foi exemplificada no incidente envolvendo o contra-almirante norte-americano Stanton, ocorrido em 21 de ou-

11 Telegrama de Salvador de Mendonça a Carlos Augusto de Carvalho, ministro das Relações Exteriores (dois despachos), de 17 de outubro de 1893 (cf. Azevedo, 1971, p.248-9). Ver também Bandeira (1973, p.142). 
tubro, ocasião em que o diplomata teve de agir em prol do governo brasileiro a partir de incidente "simples". Conforme telegrama governamental dirigido a Mendonça, Stanton havia chegado ao Rio de Janeiro, cumprimentou a bandeira dos revoltosos e não visitou as autoridades legais, procedimento comum aos membros de embarcações oficiais estrangeiras no país. Para o governo brasileiro, tal atitude traduzia o reconhecimento da beligerância dos rebeldes pelos Estados Unidos, o que daria uma nova coloração ao conflito, agravando a fragilidade do governo legal e fortalecendo o movimento contrário a Floriano Peixoto. Acresce-se ao fato, não trabalhado aqui, que a Revolta Federalista já havia se espalhado por toda Região Sul do País, tendo o governo que combater nesta outra frente de batalha.

No tocante à atitude do contra-almirante Stanton, o diplomata brasileiro reuniu-se novamente com Gresham para comunicar-lhe o fato. Após a conferência com o secretário de Estado, Salvador de Mendonça telegrafou ao Ministério das Relações Exteriores no dia 23 de outubro narrando que o procedimento de Stanton havia sido irregular e não traduzia a posição dos Estados Unidos (cf. Azevedo, 1971, p.250). A imediata remoção de Stanton do comando das forças navais norte-americanas presentes na Baía de Guanabara converteu-se em mais uma demonstração de apoio ao governo brasileiro, solidificando-o e enfraquecendo o grupo rebelde. Em meio a tal ação e ao acordo do início de outubro, as forças do governo em terra aproveitaram-se da situação de relativa calma dos bombardeios para fortificar as instalações militares que poderiam atacar as embarcações rebeldes. Essas ações contrariavam o que havia sido concordado entre as partes e foi tema de protestos da parte rebelde.

Esse "desrespeito" certamente visava à resolução mais rápida do conflito pelo governo, que, paradoxalmente, alimentou e prolongou a intervenção estrangeira no certame, expondo ambas as partes e o próprio país a críticas quanto à inexperiência e fragilidade do regime republicano, problema considerado comum na América do Sul na época. Não se pode esquecer que as potências europeias e os norteamericanos intermediavam as negociações justificando tal atitude pela defesa dos "interesses superiores de humanidade", argumento 
que camuflava os interesses econômicos envolvidos pelo conflito. Desse modo, era de se esperar que esses países enveredassem esforços para pôr fim ao conflito rapidamente. Na correspondência cabográfica de 24 de outubro, Salvador de Mendonça era noticiado sobre o argumento de que o governo brasileiro vinha fortificando instalações militares, e tal ação era considerada pelos representantes estrangeiros como uma "motivação para os rebeldes com consequências desastrosas". Por fim, o ofício dizia que "[o ministro] inglês [está] sempre dirigindo o movimento, com que pretende colocar o governo em posição coacta. Reagiremos". ${ }^{12}$

Esse posicionamento favorecia a atuação da diplomacia norte-americana no conflito, sendo vista como legítima defensora dos interesses republicanos, americanos e brasileiros, ao contrário dos elementos associados aos europeus: monarquistas e restauradores. Do lado diplomático brasileiro, as forças claramente tendiam para essa postura, que fora abalada pelo incidente com o contra-almirante norte-americano. Salvador de Mendonça relatava que no dia 25 de outubro havia conferenciado com Gresham e havia lhe dito sobre as dificuldades que o governo brasileiro vinha passando junto ao representante norte-americano no Rio de Janeiro, Thompson, que se recusava a "cooperar com as ações do governo legal". No telegrama de 26 de outubro, lê-se o seguinte:

Tive mais duas conferências Gresham relativas ao Almirante Stanton. Secretário Marinha queria tudo ficasse em nota de Gresham desaprovando proceder Stanton, mas Gresham, estando eu presente, declarou ao colega que Presidente lhe ordenara que incontinenti demitisse Stanton do comando para não pairar dúvida sobre desaprovação do seu ato. Depois Gresham me comunicou que Melo pedira Thompson reconhecê-lo beligerante dizendo haver formado Governo Provisório em Santa Catarina e poder sustentá-lo mar e terra. Cleveland hoje mandou responder que negava tal reconhecimento

12 Telegrama do Ministério das Relações Exteriores a Salvador de Mendonça, de 24 de outubro de 1893 (cf. Azevedo, 1971, p.250). 
pois que seria quebra da boa amizade que tem com o nosso Governo. Gresham revelou-me ter corpo diplomático no Rio má vontade contra nós, juntando que Thompson, homem novo, ia ter ordem até novo aviso manter-se como mero espectador. Continue notícias rebeldes para frustrar-lhes passos (cf. Azevedo, 1971, p.251).

A revogação de Stanton deu ânimo ao governo brasileiro, o qual, em novembro, passou a contar com o apoio "tácito" dos ingleses, que nos Estados Unidos, por meio de seu embaixador Julian Pauncefote, apoiaria uma intervenção norte-americana no conflito brasileiro, considerando os rebeldes como piratas. Apesar de aceitarem a proposta inglesa, os norte-americanos consideraram prudente aguardar autorização do governo de Floriano Peixoto para atuar em águas brasileiras. ${ }^{13}$

Em meio ao conflito, transparecia a desorganização institucional brasileira, que atravancava a eficácia do diálogo entre os representantes diplomáticos no País e no exterior, como a ocupação do cargo de ministro das Relações Exteriores do governo de Floriano Peixoto, com nove pessoas transitando na pasta entre 1891 e 1894. Em um momento em que se exigia uma postura internacional firme, Carlos de Carvalho deixou o cargo para que Cassiano do Nascimento o ocupasse, fazendo que o próprio Floriano Peixoto cuidasse da correspondência diplomática no fim de 1893. Em alguns telegramas datados do fim de outubro, correspondeu-se com Salvador de Mendonça a fim de obter notícias acerca da Esquadra Legal e das munições que seriam adquiridas. ${ }^{14}$

A correspondência do mês de novembro traz diversas informações acerca da compra e organização da Esquadra Legal, a qual foi organizada e armada às pressas; especialmente o telegrama do dia 15 , data em que se comemorava o quarto aniversário da proclamação da República no Brasil, trazia o seguinte conteúdo:

13 Ao considerar os rebeldes como "piratas", o governo brasileiro os excluiria da proteção da bandeira nacional, legitimando sua ação militar (Bueno, 1984, p.39).

14 Telegrama de Floriano Peixoto a Salvador de Mendonça, de 28 e 30 de outubro de 1893 (cf. Azevedo, 1971, p.251-2). 
Comunica nosso Ministro Londres seguinte telégrafo: "Correspondente especial Times Rio de Janeiro dia sete resolveram chefes revoltosos restaurar monarquia saindo Melo para o Sul, ficando Saldanha da Gama comandante esquadra. Inútil dizer Governo disposto tudo envidar manutenção República mandai notícias navios". ${ }^{15}$

As informações contidas nesse telegrama eram quase proféticas. Depois de manifestar-se neutro em relação à Revolta, Saldanha da Gama, contra-almirante consagrado internacionalmente desde o Segundo Reinado e respeitado entre civis e militares, aderiu à causa, passando a ser o comandante dos rebeldes na capital do País. Como havia predito o informante do Times, Custódio de Melo havia deixado o comando partindo para o Sul do Brasil, acreditando em um fortalecimento e em uma união das lutas que se desenvolviam ali com o conflito do Rio de Janeiro, o que, caso se concretizasse, fortaleceria a oposição contra a permanência de Floriano Peixoto no poder. Gama divulgou um manifesto no mesmo dia, justificando sua adesão ao movimento e considerando que era impelido pelo patriotismo e por seus "irmãos" que, nas campinas do Rio Grande do Sul e há três meses na baía da capital, lutavam valorosamente pela libertação da pátria brasileira do militarismo. Contudo, alguns trechos de seu manifesto causaram grande celeuma, pois demonstravam simpatia à Monarquia e aconselhavam à vontade nacional a escolha da forma que as instituições deveriam possuir.

A lógica assim como a justiça dos fatos autorizaria que se procurasse à força das armas repor o governo do Brasil onde estava a 15 de novembro de 1889, quando num momento de surpresa e estupefação nacional ele foi conquistado por uma sedição militar, de que o atual governo não é senão uma continuação. O respeito, porém, que se deve à vontade nacional livremente manifestada aconselha que ela

15 Telegrama do Ministério das Relações Exteriores a Salvador de Mendonça, de 15 de novembro de 1893 (cf. Azevedo, 1971, p.254). 
mesma escolha solenemente e sob sua responsabilidade a forma das instituições sob que deseja envolver os seus gloriosos destinos. ${ }^{16}$

A partir dessa declaração, não somente os republicanos mais radicais, alguns partícipes do campo político oficial, mas também a diplomacia nos Estados Unidos entraram em estado de alerta. Saldanha da Gama, ao assumir o comando da Revolta, entravara o comércio e desejava que "a vontade nacional" escolhesse o regime político do país, nada mais grave para indivíduos como Salvador de Mendonça que trabalhava em prol de uma americanização, subentendida aqui como republicanização, da política exterior brasileira. Mendonça (1913, p.200) mantinha, desde o período imperial, estreita amizade com Saldanha da Gama, tendo escrito que, ao saber da decisão do contra-almirante, foi preciso "procurar alento no fundo amor de minha terra para prosseguir na tarefa que a consciência impunha", ou seja: lutar do lado oposto ao amigo. ${ }^{17}$

Consequentemente à mudança na chefia do lado rebelde, as dificuldades em organizar e despachar dos Estados Unidos as embarcações que comporiam a Esquadra Legal faziam o governo brasileiro procrastinar suas ações. Ainda em dezembro, o secretário de Estado norte-americano queixava-se a Salvador de Mendonça de que Floriano Peixoto havia inadvertidamente mudado o local de desembarque de mercadorias no porto para outro local, situando as embarcações estrangeiras na linha de fogo dos revoltosos (cf. Mendonça, 1913, p.209). A atitude do representante norte-americano expunha a mudança do posicionamento dos Estados Unidos ante o conflito, que parecia acreditar em uma vitória dos rebeldes. Salvador de Mendonça procurou logo reunir-se com Gresham e respondeu ao norte-americano que a alteração do local de descarga havia sido deliberada após ameaças dos revoltosos de bombardear a cidade, ao tempo que o governo deveria responder com a artilharia em terra.

16 Manifesto de Saldanha da Gama, de 7 de dezembro de 1893 (cf. Carone, 1969, p.28-30).

17 Cabograma do Ministério das Relações Exteriores a Salvador de Mendonça, de 12 de dezembro de 1893 (cf. Azevedo, 1971, p.257). 
Mesmo assim, Gresham não se satisfez, argumentando que nada tinha a ver com as lutas internas do país e ia ordenar ao responsável pelas embarcações norte-americanas que não obedecesse às ordens do governo brasileiro. Segundo o diplomata brasileiro, a postura hesitante de Gresham ligava-se a fato semelhante no Chile, quando os Estados Unidos posicionaram-se ao lado do governo legal e este fora derrotado, tendo que, assim, conviver com a má vontade dos vencedores. Mendonça então replicou que, pensando dessa forma, era justificável que o governo norte-americano assumisse uma postura neutra no conflito e retirasse o "apoio moral" até então dado a Floriano Peixoto, e, para tanto, considerasse como beligerantes os revoltosos.

A atitude de Salvador de Mendonça certamente era um blefe, pois logo depois mostrou a Gresham o cabograma de 18 de novembro de 1893 em que o Ministério das Relações Exteriores do Brasil narrava a Mendonça que Thompson parecia não agir como "mero espectador do conflito" e, pelo contrário, era simpático às ações do representante inglês, que nutria certa confiança acerca da vitória da esquadra rebelada (cf. Azevedo, 1971, p.255). Salvador de Mendonça lembrou-lhe que a postura neutra dos Estados Unidos abriria espaço não só para projetos restauradores da Monarquia, mas também para a retomada da Inglaterra, que vinha perdendo a "preferência" nas negociações bilaterais com o Brasil. Além disso, o diplomata brasileiro advertia Gresham acerca de um afastamento repentino entre os dois países, que desde 1889 haviam inaugurado um relacionamento jamais visto em suas trajetórias, o que implicaria à manifestação da opinião pública norte-americana crítica severa às atitudes do governo Cleveland, que havia requisitado o retorno da Monarquia no Havaí dias antes.

Salvador de Mendonça usava de seu prestígio no Poder Executivo norte-americano para deliberar em prol dos interesses do Brasil e dos Estados Unidos, pois não escondia ao secretário de Estado que a resolução do conflito - afiançada por seus homens - seria a garantia do incremento de relações comerciais mais sólidas, sustentadas por uma política comum, ainda que mais favorável aos norte-americanos. Após o encontro com Mendonça, Gresham conferenciou com Cle- 
veland, que pediu a remoção do responsável norte-americano na baía e já fornecia ordens ao contra-almirante Benham, na ilha de Trindade, para que rompesse o bloqueio rebelde caso fosse impedido de descarregar as mercadorias dos Estados Unidos. ${ }^{18}$

Benham chegou ao Rio de Janeiro com instruções claras: não reconheceria os revoltosos como beligerantes. Comunicou o fato em nota ao contra-almirante Saldanha da Gama dizendo que desconhecia sua autoridade para vistoriar embarcações neutras ou mesmo apreender mercadorias consideradas contrabando de guerra, e a insistência dessas ações levá-lo-ia a considerar Saldanha como pirata. Em 29 de janeiro, Benham finalmente agiu. Os Estados Unidos não reconheciam o bloqueio comercial imposto pelo comando da revolta e - nas palavras de Salvador de Mendonça - estavam prontos para rompê-lo à força. Quando os rebeldes tentaram impedir a movimentação de embarcações norte-americanas, "reagiu com tiro real e disposição para o combate”. Essa ação, segundo Bueno (1995, p.183), dissipou o problema de trânsito das mercadorias neutras, abateu o moral da Revolta e retirou um de seus principais triunfos: o bloqueio do porto do Rio de Janeiro.

O governo brasileiro, mesmo após a ação enérgica de Benham, enviou cabograma a Salvador de Mendonça em 7 de fevereiro dizendo que os agentes diplomáticos estrangeiros tendiam ao reconhecimento dos revoltosos como beligerantes e que fizesse todo o possível para evitar tal atitude nos Estados Unidos (cf. Azevedo, 1971, p.260). No dia seguinte, Mendonça respondeu dizendo que Gresham mantinha sua posição de 22 de dezembro (de apoio ao governo brasileiro) e pedia que Thompson ficasse junto ao governo, ou seja, se afastasse do posicionamento europeu simpático à restauração monárquica (ibidem). Alguns dias antes, o jornal norte-americano The New York Times publicava artigo de Salvador de Mendonça intitulado Aspects

18 As informações da reunião de Gresham e Mendonça são relatadas no longo Ofício Confidencial no 1, de 23 de dezembro de 1894, no qual o representante brasileiro narrou o trabalho da legação brasileira durante a rebelião (cf. Azevedo, 1971, p.269-76). Ver também Bueno (1995, p.187-8). 
of the brazilian rebellion, no qual o diplomata historiava o conflito, atacando duramente os argumentos de Custódio José de Melo e Rui Barbosa, que havia fomentado a sedição da Armada no exterior por meio da imprensa, posicionando-se contrariamente a Floriano Peixoto, cujo governo era ilegal e ditatorial.

Rui Barbosa havia auxiliado na composição das instituições republicanas segundo o modelo das americanas (Constituição de 1891), porém apoiava as advertências de Eduardo Prado no tocante à aproximação do Brasil com os Estados Unidos, considerando sua obra um "feito de ciência, verdade e patriotismo". Classificava como "perigosa" a intenção de se erguer uma estátua a Monroe como sinal de reconhecimento à simpatia norte-americana e também atentaria para o caráter exclusivamente (norte) americano que a Doutrina Monroe possuía, algo que configurava uma "limitação da soberania das outras Repúblicas a cuja causa a Democracia de Washington nunca se irmanara" (Bandeira, 1973, p.149-50).

Em síntese, o artigo de Salvador de Mendonça possuía alvos claros: os monarquistas, identificados como "inimigos" da República, e as nações estrangeiras, prejudicadas com a paralisação do comércio no Rio de Janeiro. O objetivo era persuadir os leitores norte-americanos das dificuldades e dos problemas subjacentes a uma possível restauração do antigo regime político brasileiro. Seguem as palavras de Mendonça (1894), traduzidas do inglês:

Os interesses das nações estrangeiras, que nos nossos tempos estão dirigidos antes para a conquista de novos mercados para os seus produtos do que reconstruir tronos para príncipes desempregados, assentam no restabelecimento da paz na grande República sul-americana. Na improvável hipótese da vitória dos restauradores no Brasil, a paz seria impossível, porque o restabelecimento da monarquia assinalaria o início de uma guerra civil de duração indefinida e que poderia apenas terminar como a aventura napoleônica no México [...].

De forma paralela, a Esquadra Legal, que foi ridicularizada pela imprensa brasileira como a "Esquadra de Papelão", finalmente 
chegava ao País, composta por três navios nomeados de Niterói, Andrada e América, três vapores, transformados em torpedeiras e que receberam os nomes de Moxotó, Poty e Inhanduhy, além da tripulação, comandada pelo contra-almirante Jerônimo Gonçalves e recrutada nos Estados Unidos. Esta fora composta majoritariamente por mercenários - norte-americanos -, que receberam o pagamento antecipadamente, e, no Brasil, causou indagação de autoridades e intelectuais, que a consideraram uma vergonha e um escândalo, por causa da desordem provocada por ocasião de uma parada em Recife. A função da "Esquadra de Papelão" era dissipar por completo a Revolta, o que indiretamente significava a complementação do trabalho executado pelo contra-almirante Benham (Bandeira, 1973, p.144).

No dia 11 de março de 1894, os rebeldes encontravam-se praticamente sem provisões e munição, o que os levou a entregar a proposta de rendição ao governo, assinada por Saldanha da Gama, com as condições: retirada para o estrangeiro dos oficiais sob garantia e guarda de Portugal; garantia de vida para os inferiores e voluntários engajados no conflito; entrega de fortalezas, navios e material no pé em se encontravam; e restituição dos prisioneiros feitos pelo governo. A resposta de Floriano Peixoto não demorou: o governo não aceitaria as propostas dos militares rebeldes (Azevedo, 1971, p.261). No dia seguinte, o governo brasileiro divulgou nota em que dava o prazo de 48 horas para que os rebeldes se entregassem, caso contrário, abriria fogo contra as embarcações. Findo o prazo, o governo as bombardeou, verificando, porém, que elas haviam sido abandonadas na noite anterior, e a tripulação, abrigada em navios de guerra estrangeiros. ${ }^{19}$ As embarcações de Portugal acolheram cerca de quinhentos revoltosos, que do Rio de Janeiro foram para Montevidéu sob fortes protestos do Ministério das Relações Exteriores do Brasil, que exigia a entrega dos oficiais, considerados criminosos comuns e não presos políticos.

19 Cabograma do Ministério das Relações Exteriores a Salvador de Mendonça, de 14 de março de 1894 (Azevedo, 1971, p.262). 
Várias justificativas foram dadas para a ação portuguesa. O governo português, que ainda era uma Monarquia, ${ }^{20}$ entendia que os rebeldes eram criminosos políticos, portanto não poderiam ser julgados como prisioneiros comuns, daí a razão para o asilo. Do lado brasileiro, entendia-se que a atitude do comandante português era motivada por sentimentos humanitários, porém o governo via-se na obrigação de reclamar a entrega dos indivíduos que não tinham direito de gozar de tal proteção. Os jacobinos também se manifestaram pela imprensa, acreditando que a manobra portuguesa nada mais era do que uma ocasião para o recomeço das hostilidades (Heinsfeld, 2007, p.4-5).

Tal pedido não encontrou receptividade em Portugal, que informou ao representante brasileiro em Lisboa que os asilados "seriam transportados para terras portuguesas em navios portugueses, internados em estabelecimentos militares, vigiados e fiscalizados de modo a não voltarem ao Brasil a perturbar a sua ordem interna" (Bueno, 1995, p.201).

A leitura da correspondência diplomática de Salvador de Mendonça permite entrever que essa discussão chegou aos Estados Unidos. No fim do mês de março de 1894, ele reuniu-se com Gresham a fim de levar ao conhecimento do secretário de Estado o impasse sobre a entrega dos rebeldes acolhidos pelos portugueses. Perguntado sobre um possível posicionamento na disputa, Gresham não achava correto os Estados Unidos se colocarem como árbitros na questão, ao passo que já haviam agido extraordinariamente em favor do governo de Floriano Peixoto no Brasil e até mesmo na Europa. ${ }^{21}$ No cabograma do dia 27 de março, Mendonça ainda diria que Gresham, ao receber pressão de diplomatas ingleses e italianos pela recusa na entrega dos rebeldes, recusara tal apoio, declarando que estes não poderiam ser asilados em águas territoriais brasileiras, ao contrário do que deveria

20 Dom Carlos I (dos Braganças) era o rei de Portugal durante a Revolta da Armada, o que também traduzia o interesse em asilar adeptos do regime político em seu país.

21 Cabograma de Salvador de Mendonça ao Ministério das Relações Exteriores, de 21 de março de 1894 (cf. Azevedo, 1971, p.263). 
ter sido feito no caso de os rebeldes terem ultrapassado ou aportado em terra estranha. Para o secretário norte-americano, tal ação havia ofendido a soberania brasileira (cf. Azevedo, 1971, p.263). O desenlace da querela foi a suspensão das relações entre Brasil e Portugal nos meses seguintes, ao passo que Mendonça foi indicado pelo governo brasileiro para que intercedesse junto ao norte-americano no sentido de este proteger os brasileiros residentes no país europeu durante tal ato. Conforme nota de 31 de março, o governo dos Estados Unidos acedia quanto ao pedido brasileiro (ibidem, p.264).

A ligação histórica entre os dois países era então abalada, marcando de forma exemplar o processo de americanização do Brasil. Especificamente nesse relacionamento, desde a proclamação da República as relações entre brasileiros (republicanos) e portugueses não andavam bem. Alinhados com o posicionamento europeu, estes hesitaram no reconhecimento do novo regime, recebendo críticas por tal postura, como quando o governo brasileiro resolveu promover a chamada "grande naturalização", na qual os estrangeiros residentes no país seriam declarados brasileiros somente se eles se manifestassem de forma contrária. Uma crescente hostilização ao elemento lusitano-monárquico fez diminuírem as remessas em dinheiro enviadas do Brasil a Portugal por seus cidadãos (Heinsfeld, 2007, p.2).

A despeito das discussões em torno da Revolta, importa saber que tanto a diplomacia europeia quanto a norte-americana não se definiam primordialmente a partir do regime republicano, daí a possibilidade aventada pelos Estados Unidos de retirar o apoio moral ao governo brasileiro quando este se enfraqueceu, em dezembro de 1893. Nesse sentido, confirmavam-se as ideias de Eduardo Prado de que o Brasil não se poderia pautar pelas relações com os países (especificamente os Estados Unidos) a partir do regime político (republicano). O real interesse no conflito, seja de qualquer potência que teve alguma participação interventiva, era o grau de privilégios adquiridos com seu transcorrer. Nesse sentido, a derrota de Floriano Peixoto traduzia a derrota da diplomacia norte-americana no Brasil, fato habilmente articulado por Salvador de Mendonça que justificava a intervenção estrangeira por meio do relacionamento cada vez mais próximo 
entre os dois países, ainda que utilizasse em primeiro lugar o argumento político, secundado pelo econômico (Bueno, 1984, p.45-50).

A Revolta da Armada, para além de possuir esse significado exterior, representou internamente a vitória do principal grupo que apoiou o governo de Floriano Peixoto no certame: os paulistas. Para as lideranças políticas e econômicas do Estado, uma revolta bem-sucedida encorajaria outras e fortaleceria os militares, daí o sentido do apoio a Floriano Peixoto, que, bem-sucedido na capital federal, contou com o auxílio das milícias estaduais paulistas para conter o avanço dos federalistas do Sul para o Sudeste do País. A historiografia sobre o período trata Floriano Peixoto como o consolidador da República, mesmo que o adjetivo comporte diversas problematizações, tais como a sua permanência no poder, contrariando a Constituição, o longo período em que lançou o Brasil em estado de sítio e as rígidas medidas contra opositores.

O período eleitoral, marcado para março de 1894, assinalou a complexa rede de problemas que o novo presidente enfrentaria: uma série de focos de oposição no Exército, no funcionalismo público e em alguns governadores. A Revolta da Armada havia distribuído promoções aos simpatizantes do florianismo que puderam ascender à cúpula militar, e, no serviço público, a pressão por empregos crescia mês a mês, da mesma forma que nos Estados a disputa entre os nomeados pelo vice-presidente e seus adversários representava uma das faces do republicanismo no Brasil: a inexperiência e a desorganização, convergidas na dificuldade de conciliação entre grupos e tendências políticas, uma das características peculiares do Segundo Reinado. Novos desafios apareciam no horizonte da República brasileira.

\section{Salvador de Mendonça e a despedida da diplomacia: entre Washington e o Rio de Janeiro}

Os últimos quatro anos que Salvador de Mendonça permaneceu nos Estados Unidos foram marcados pelos ecos que a Revolta da Armada e a intervenção estrangeira (norte-americana) tiveram 
na opinião pública: imprensa e intelectuais atacaram duramente a postura do governo brasileiro, inclusive a atitude de Salvador perante os rebeldes, que haviam sido abrigados pelos portugueses presentes no porto do Rio de Janeiro, motivando o rompimento das relações diplomáticas entre Brasil e Portugal. Diversos indivíduos manifestaram-se ante a situação, produzindo obras instigantes para o debate historiográfico sobre o período, trazendo à tona posicionamentos favoráveis e contrários ao governo de Floriano Peixoto. Essas posturas acabavam transparecendo a própria concepção de República que esses indivíduos possuíam e exprimiam o debate que parecia não se encerrar entre os monarquistas e os republicanos, estes últimos profundamente divididos.

Concomitantemente à Revolta da Armada, ocorriam as eleições para o Congresso e a presidência do Brasil. O Partido Republicano Federal, que havia apoiado integralmente Floriano Peixoto, unia suas forças para "cobrar" eleitoralmente dos florianistas tal atitude, ou seja, desejando a construção de um cenário político que lhes fosse favorável, apesar das enormes disputas existentes. Assim, nas eleições de 1894, o Partido Republicano Federal conquistou a presidência com a eleição do paulista Prudente de Moraes; um terço do Senado e a totalidade da Câmara dos Deputados. Como observa Renato Lessa (1988, p.143), o eleitorado potencial do País naquele ano era de cerca de 110.000 pessoas, contudo votaram apenas 7.857 eleitores, e tal "abstenção" não se configurava como um problema para os homens no poder. Importava-lhes, sobretudo, o relacionamento entre os atores com posições privilegiadas no poder (Executivos estaduais, burocracias, Legislativos estaduais e o Congresso Nacional) com o governo (Carone, 1971a, p.137). Esses atores não conseguiam formular uma resposta institucional sólida o bastante para que houvesse uma harmonização interna (entre os Estados e a Federação), condição indispensável para a boa condução dos negócios externos, sejam eles de natureza política, econômica ou militar, como no caso da Revolta da Armada.

No ofício confidencial no 2, de 28 de julho de 1894, Salvador de Mendonça exprimia indiretamente essa desorganização no plano 
externo. Contava que durante a Revolta no Rio de Janeiro, todos os oficiais dos consulados brasileiros nos Estados Unidos deviam se reportar a Washington (a ele) antes de deixar embarcar qualquer tipo de munição, armas ou outros objetos para os portos brasileiros, com o fito de prevenir o contrabando para os revoltosos. Entretanto, foi-lhe notificado que um representante do País, talvez simpático à causa rebelde, tentou mais de uma vez conceder despacho de munições bélicas para o Brasil, ocultando o fato aos superiores. Também recomendava a Cassiano do Nascimento, então ministro das Relações Exteriores, a demissão do indivíduo, não identificado no ofício (cf. Azevedo, 1971, p.266-76).

Eleito em março de 1894, Prudente de Moraes foi empossado em 15 de novembro do mesmo ano, consagrando-se como o primeiro presidente civil do Brasil, tendo diante de si diversos problemas inaugurados com o regime republicano, porém sem solução até o momento. Entre estes, figurava a disputa entre civis e militares, que Moraes procura despolitizar e redefinir cargos imediatamente à sua posse, dissolvendo os batalhões patrióticos criados durante a Revolta da Armada e retirando militares de cargos civis, gerando enorme descontentamento. Para executar essa política de "retração militar", Prudente restaurou as publicações proibidas durante o governo de Floriano Peixoto, possibilitando a divulgação de notícias até então ocultadas pelos militares nos anos anteriores. Foram reveladas atrocidades cometidas não somente na capital federal, mas no Sul do País, como o massacre promovido pelo coronel Moreira César em Santa Catarina em nome de Floriano Peixoto e do governo legal (Lessa, 1988, p.77-8).

Os setores atacados direta ou indiretamente pelo governo recém-empossado não receberam tais atitudes passivamente. No Congresso, os setores florianistas do Partido Republicano Federal atacaram suas deliberações, expondo a ideia de que as relações entre os poderes Executivo e Legislativo ainda se mantinham conflituosas, cada qual procurando interferir em maior medida nas atribuições respectivas.A intermediação entre o Congresso e o presidente era feita por Francisco Glicério, vice-presidente, que já se comportava de 
modo a se aliar aos setores florianistas. Um exemplo interessante desses descaminhos era o da intervenção do Executivo na política financeira do País, que havia herdado enormes dívidas e déficits agravados pela queda internacional dos preços do café. Engessado pelos tributos cobrados sobre a importação de mercadorias e sem uma base sólida de apoio no Congresso para a aplicação de uma política alternativa, a solução adotada acabou sendo a realização de dois empréstimos para conter os problemas financeiros do País (ibidem, p.80).

O governo de Prudente de Moraes, tanto pelas circunstâncias anteriores às suas ações quanto por suas medidas antiflorianistas, conviveu com o nascimento de um grupo que, gradativamente, passou a lhe fazer oposição, refletindo a tensão dos primeiros anos republicanos no processo de reaglutinação de grupos e segmentos de poder: o jacobinismo. O movimento se iniciou durante a Revolta da Armada, quando as ações de Floriano Peixoto ante os rebeldes e contra os indivíduos pró-Monarquia passaram a catalisar diversas manifestações nacionalistas que reivindicavam a permanência dos militares no poder, à medida que vinha conseguindo conter as forças contrárias à República, ainda que, para tanto, fossem necessárias medidas enérgicas (Queiroz, 1986, p.12-26).

Nesse sentido, os jacobinos atacaram ferozmente, durante todo o mandato de Prudente de Moraes, qualquer afastamento da política do marechal Floriano Peixoto, relembrando seu governo e seus feitos. De longe, o novo presidente não se adequava à retórica castrense jacobina, empenhando-se em encerrar a fase turbulenta dominada pelos militares e consolidar o domínio civil, o que avolumou as críticas - violentas - dos jacobinos de plantão (ibidem, p.13-31).

A popularidade de Floriano Peixoto após sua saída do governo cresceu enormemente, chegando ao ápice com sua morte, em 29 de junho de 1895. Para seus adoradores, ele traduzia-se na "suspeição desconfiada para com o estrangeiro" e na extrema suscetibilidade aos arranhões que o brio nacional viesse sofrer. Sua habilidade política era vista na frieza com que tratava os problemas políticos e nas ações benevolentes, como quando tabelou preços de gêneros alimentícios e se propôs a construir casas populares, enfrentando antigos pro- 
prietários que exploravam classes pobres na capital federal (ibidem, p.133-150).

A heroicização de Floriano Peixoto ajudou a solidificar a imagem atribuída a ele de "consolidador da República", engrossando o caldo oposicionista contra Prudente de Moraes. As comparações entre as posturas dos dois indivíduos foram frequentemente discutidas, chegando-se, inclusive, ao enfrentamento físico nas ruas do Rio de Janeiro, cidade na qual o movimento possuía grande força.

A posse de um presidente civil era vista pelos jacobinos como um desvio dos caminhos progressistas que o País havia iniciado em 1891, e, assim, eles direcionaram suas críticas aos paulistas, interessados na solidez política como garantia da manutenção da economia de exportações, sustentáculo do País. Os jacobinistas lutavam contra os paulistas (e os civis no poder em sua grande maioria) porque se julgavam portadores do paradigma de República adequado ao País, e esta deveria ser forte e centralizada, pois o Brasil não poderia aceder com qualquer movimento de separatismo e excessiva autonomia regional. Portanto, o nacionalismo era uma das mais poderosas características do grupo jacobino, que, ao longo do governo de Floriano Peixoto e até o fim do mandato de Prudente de Moraes, fiscalizou não somente os homens no campo político republicano, mas o próprio Estado (ibidem, p.88-98).

A referência ao elemento estrangeiro era outra importante característica do grupo jacobino, pois, já que valorizava excessivamente o elemento nacional, seu contraponto era duramente atacado. Quem sofreu bastante com essa postura foram os portugueses, ainda que os ingleses e europeus em geral fossem frequentemente criticados, pois a eles eram creditados o atraso econômico do País e o passado colonial dependente, cabendo a um novo governo, de cunho militarista, conduzir o Brasil rumo ao progresso. Na aplicação desses valores, encontra-se na Revolta da Armada um exemplo interessante de contradição ou exceção do grupo. O pedido de intervenção para dissipar o movimento rebelde veio do governo legal, porém foi efetuado diretamente pelos norte-americanos, estrangeiros, sendo algo passível de ressalva negativa pelos jacobinos. Não foi o que consideraram. Os 
Estados Unidos, e somente esse país, eram tomados como exceção no continente e como estrangeiros. Em jornais de tendência jacobina, lia-se que o Brasil precisava aproximar-se mais dos norte-americanos, pois era na integridade do Novo Mundo que o País poderia crescer economicamente (ibidem, p.106-7).

No contexto de americanização da esfera estatal, essa postura do movimento jacobino apresentava-se, antes de tudo, como tendência política que poderia "purificar" o elemento degenerador europeu, servindo como instrumento à tão aclamada Doutrina Monroe, que atingia seu ápice no período em que Grover Cleveland presidia os Estados Unidos. A manifestação dos jacobinos no Brasil refletia o poder de "atração" que os Estados Unidos já exerciam perante seu continente, imprimindo a noção de que progresso material, desenvolvimento econômico e nível educacional elevado, ligados a instituições políticas sólidas, nada mais eram que sinais claros de civilização (Malatian, 2007, p.44-5). Aplicar essas noções no Brasil, ao contrário de praticamente toda e qualquer ideia oriunda do continente europeu, era visualizar o desenvolvimento e o crescimento do País.

O fracasso da Revolta e a vitória de Floriano Peixoto firmaram uma nova fase de atuação dos jacobinos, que ganharam os paulistas - cafeicultores e defensores da descentralização administrativa do País - como opositores, além dos monarquistas, que não deixaram de se manifestar, entre eles Eduardo Prado, que os considerava a "síntese do que havia de mal no governo republicano", à medida que defendiam um governo despótico e militarizado. Aliás, esta última característica era tacitamente rechaçada no Segundo Reinado, que priorizava a Guarda Nacional e não o Exército. ${ }^{22}$ Os monarquistas, representados por Prado, ainda se aproveitavam das efusões jacobinistas para comparar a República brasileira com as demais sul-americanas, nas quais o elemento militar predominava no cenário

22 A Guarda Nacional foi uma força militar organizada no País durante o período regencial (1831) com a função de garantir a ordem e a segurança do Império. Ao longo do Segundo Reinado, a politização da Guarda Nacional passou a fornecer prestígio e visibilidade social a seus membros, que em 1864 chegaram ao número de seiscentos mil, em oposição aos dezesseis mil do Exército regular. 
político, redesenhando alianças, governos e assembleias. Por sua vez, Rui Barbosa e Américo Werneck criticavam duramente o caráter militarista dos primeiros anos da República e, por conseguinte, os jacobinistas, que, para eles, deveriam servir à nação obedecendo-lhe, não promovendo sedições ou estimulando mudanças de governos. Mas não partilhavam dessa visão Assis Brasil, Nilo Peçanha e Francisco Glicério, que entendiam o movimento com um caráter muito mais idealista do que intolerante, considerando-os como um instrumento de crítica e vocalização das discordâncias no campo político que careciam ser debatidas (Queiroz, 1986, p.164-73).

A pluralização de vozes em prol deste ou daquele grupo político era frequente nos anos iniciais do regime republicano, e, após a Revolta da Armada e a eleição de um civil à presidência do País, surgiram diversos "balanços" do que havia ocorrido até então no âmbito político, econômico e social. As perguntas que pairavam sobre a intelectualidade da época tendiam do presente para o futuro: "como agir perante os anos que virão?” depois de diversas lutas internas e a intervenção estrangeira no País sob a República. É justamente nesse sentido que o conflito entre a Marinha, liderada inicialmente por Custódio de Melo, e o governo de Floriano Peixoto apontaria uma série de questões no horizonte historiográfico, revelando a formulação de um novo comportamento político.

Em meio a essa discussão, a obra de Joaquim Nabuco (1939), intitulada A intervenção estrangeira durante a revolta de 1893, se torna referencial, pois analisa o conflito em questão utilizando como referência o elemento externo, tornando-se adequada para a reflexão sobre a diplomacia como instrumento de negociação dos interesses do país, no caso do Brasil, que, mesmo não declaradamente, acreditava-se dependente dos Estados Unidos na manutenção da República. Por sua vez, a obra de Felisbelo Freire (1982) compõe visão diversa da de Nabuco. Em História da Revolta da Armada de 1893, Freire discute os aspectos internos do conflito e a sua história diplomática, de grande importância para sua resolução em prol do governo de Floriano Peixoto. Ao colocar em discussão as duas obras, pretende-se clarificar algumas das tendências existentes no período 
e, dessa forma, como enxergavam a atuação da diplomacia em prol da República brasileira.

A obra de Nabuco foi escrita em um período de ostracismo do autor, quando ainda não havia aderido à República. Joaquim Nabuco iria se converter com Rio Branco na década seguinte para a formação da embaixada do Brasil em Washington, passando a defender o monroísmo e a crescente aproximação com os Estados Unidos. A leitura da obra revela seu posicionamento no momento: defensor da soberania e integridade nacionais, a despeito dos conflitos internos provocados pelo governo de Floriano Peixoto.

As turbulências provocadas pelo militarismo jacobino, adjetivado por ele como um "pastiche histórico", não poderiam permanecer ocultas, pois o conflito expunha não somente um governo autoritário colocado em xeque por uma parte da Marinha, mas também a grande inexperiência dos homens no poder quanto à manutenção dos interesses nacionais.

Felisbelo Freire ${ }^{23}$ era um médico e político sergipano que ocupou diversos cargos nos anos iniciais da República e era a personificação da instabilidade institucional do governo de Floriano Peixoto. Foi governador de Sergipe, ministro das Relações Exteriores, da Fazenda e da Justiça somente entre os anos de 1893 e 1894. Freire, menos conhecido que Joaquim Nabuco no cenário intelectual, procurou, por meio de suas obras, analisar o período pelo qual atravessava o Brasil e, nesse sentido, escreveu A história constitucional da República dos Estados Unidos do Brasil, com o fito de analisar a formação do regime republicano brasileiro e, em outro momento, a reflexão sobre a Revolta da Armada, obra aqui debatida. O cotejamento das obras dos respectivos autores justifica-se pelo fato de se situarem em campos opostos da contenda político-militar, assentando-se em posições definidas quanto às ações do governo legal e às intervenções estrangeiras.

23 Os autores e editores que citam Felisbelo Freire parecem não uniformizar a grafia do nome do político sergipano. Nas consultas realizadas, encontram-se "Felisberto", "Filisbelo" e, por fim, "Felisbelo". Optou-se pela grafia Felisbelo, como encontrado na edição da obra do autor ora analisada. 
Felisbelo Freire divide o conflito em três fases, ao contrário da bibliografia, que entende haver apenas dois momentos: o conflito entre a Esquadra e o governo. As fases são marcadas pelo acordo de 5 de outubro, a entrada de Saldanha da Gama no conflito, e daí até março de 1894, quando os rebeldes se asilam nas embarcações portuguesas. $\mathrm{O}$ autor balizou-se na gradativa inserção do discurso monarquista na ação dos rebeldes, que justificaram sua derrota à intervenção estrangeira, para Freire (1982, p.10-2) uma versão errônea dos fatos. Como republicano sintonizado com o discurso florianista, Freire se posiciona na obra justificando a ação governamental, argumentando que os rebeldes não acreditavam na resistência prolongada de Floriano Peixoto: obcecados pelo poder, não investiram tanto na luta em si, mas na queda de um governo no qual não viam legalidade jurídica ou nacional, assentando seus argumentos nas arbitrariedades do Executivo na deposição e intervenção nos Estados.

O autor compartimenta a Revolta sob dois grupos de "causas" políticas e sociais -, ainda que o elemento econômico permeie todo o conflito. As causas políticas envolviam, sobretudo, a deposição do "chefe da nação", ao passo que as sociais rodeavam as disputas entre o Exército e a Marinha, desprestigiada com o advento da República.

O marco da crise política havia sido o manifesto dos treze generais que prenunciou a ação "revolucionária" dos membros da esquadra. Freire (1982, p.22) não entendia haver inconstitucionalidade no ponto questionado pelos generais, pois "o aresto do poder legislativo firmou a doutrina de que o primeiro período presidencial devia ser regido por uma disposição transitória da constituição, que não obrigava a nova eleição". Para fundamentar sua defesa, Freire voltou-se à história constitucional dos Estados Unidos, considerando que o processo contra Floriano Peixoto era um caso similar, pois, na sucessão de Lincoln, Andrew Johnson também enfrentou críticas e processos contra sua ascensão à presidência, conseguindo sair vitorioso de todas as acusações. Assim o poderia fazer Floriano Peixoto, que vinha procurando sustentar o crédito do País no cenário internacional, a despeito da grave crise financeira, ao mesmo tempo que se digladiava com o poder Legislativo e as críticas na imprensa, 
comandadas pelo senador Rui Barbosa (ibidem, p.45-51). Esse era o pano de fundo quando o conflito foi instaurado pelos revoltosos, ou seja, de instabilidade política ocasionada pela dificuldade em harmonizar os poderes e suas atribuições.

[A República] não era uma obra estável de organização. Foram inúmeras as irregularidades, que afetavam diretamente o princípio da autoridade, como a instituição dos dois governos, que se julgavam eleitos, em Goiás, a eleição ilegítima de governador, que não era a expressão da maioria do sufrágio, em Sergipe, a eleição de dois congressos, em Alagoas [...]. O resultado disto foi que a organização dos estados tornou-se um edifício construído em bases instáveis e movediças (Freire, 1982, p.54).

A crítica de Freire sinaliza o problema já discutido do novo regime: a ausência de um pacto político que sustentasse as instituições e seus atores, impedindo a formulação de projetos internos e de política externa. O câmbio entre esses dois planos, tomada aí a referência dos Estados Unidos, revela-se como fundamental no entendimento de uma relação de "dependência", simbólica ou pragmática. O governo iniciado por Deodoro, como o autor exemplifica, já possuía traços de desorganização institucional, desencadeando atritos que culminaram com a Revolta em setembro de 1893.

No conjunto de causas sociais, Freire atribuía ao grau de participação no regime, fato que rendia status aos segmentos de elite republicanos, o ponto nevrálgico da luta, especificamente a rivalidade entre os setores do Exército e da Marinha que aspiravam à ascensão política. O Exército havia se aproximado da propaganda republicana, dando repercussão às querelas entre a Monarquia e seus membros; havia colocado um general de suas fileiras como chefe do governo provisório, posteriormente elegendo-o presidente (além do vice, também do Exército); e, por fim, foi majoritariamente representado no Congresso e nos Estados do País. Essa disparidade foi notada exemplarmente por Custódio de Melo, que deixou o cargo de ministro da Marinha para iniciar atos de hostilidade e descon- 
fiança contra o governo de Floriano Peixoto, atitudes agravadas por suas pretensões de candidatar-se à presidência para o governo de 1894-1898 (ibidem, p.59-66, 81).

O caráter "pessoal" de parte das motivações da Revolta levou o então prestigiado contra-almirante Saldanha da Gama a se colocar em posição de neutralidade no conflito. A despeito de tal posição, a primeira fase do certame ficou caracterizada a partir de posturas políticas alinhadas com o movimento monarquista, que no Rio de Janeiro possuía enorme força, mesmo com dificuldades de se organizar após a queda do Império. Como pinça Janotti (1986, p.83), "não era fácil congregar liberais e conservadores ainda ressentidos e culpando uns aos outros pela ruína da Monarquia". Assim, o grande temor dos republicanos, principalmente os situados na capital federal, era a ação desse grupo por trás dos revoltosos, algo permeado na correspondência diplomática e na obra de Felisbelo Freire.

Freire (1982, p.86) acreditava que para a "vitória da revolta importava a morte das instituições republicanas", não podendo o governo deixar de deter a "onda restauradora". Contando com apoio suficiente das elites exportadoras de café e parte do Congresso, Floriano Peixoto agiu requerendo deste a autorização para decretar o estado de sítio, conseguindo sua aprovação em 10 de setembro de 1893. A situação do conflito não permitia ao governo assumir desde logo uma postura ofensiva, pois colocava em perigo o Rio de Janeiro e a cidade de Niterói, na mira dos revoltosos, que bombardeavam diariamente as fortalezas situadas na baía, preocupando não só os membros do campo político, mas os representantes estrangeiros presentes na capital.

Ao longo do mês de setembro, foram desenvolvidas as negociações que engendraram o acordo de 5 de outubro, firmando um modus vivendi para o conflito, inteiramente negociado pelos representantes europeus que excluíram a presença dos diplomatas sul-americanos nas reuniões. Para o governo brasileiro, essa postura traduzia a simpatia europeia pela Revolta, e para tanto agiu com "enérgica prudência”: fez publicar um boletim em que declarava: 
Tendo sido espalhados boletins em que se admitia a possibilidade de ser esta Capital entregue à anarquia e ao saque, o governo declara que dispõe de todos os elementos para manter a ordem e que fará imediatamente fuzilar todo aquele que atentar contra a propriedade particular (Freire, 1982, p.112-4).

O acordo de 5 de outubro marcava o início da segunda fase da Revolta, delineando, segundo Freire, o agravamento das tensões entre o governo e os rebeldes, que não cumpriram o que fora estabelecido em momento algum: ainda no dia de assinatura do acordo, os rebeldes bombardearam as embarcações que descarregavam na baía. Entre 12 e 30 de outubro, impedidos de atacar o Rio de Janeiro, os revoltosos o fizeram em Niterói, destruindo diversos edifícios na cidade. ${ }^{24}$

No Congresso, batiam-se os adversários e simpáticos ao conflito. Ganhou destaque o projeto apresentado por Nilo Peçanha cujo fito principal era declarar os navios rebeldes como piratas, o que não foi discutido na casa legislativa e também não encontrou eco no corpo diplomático estrangeiro, que Freire entendia dar aos insurgentes mais simpatias à condição de beligerantes do que militares rebeldes. Do lado destes, situava-se Rui Barbosa, que atacava, no Jornal do Brasil, os atos do governo de Floriano Peixoto, que estaria condenando à morte os membros das famílias dos revolucionários e suspeitos, além de proibir a divulgação de notícias sobre o conflito pela imprensa. De fato, o governo havia "regulado" seu funcionamento durante a vigência do estado de sítio, justificando sua atitude no argumento de que uma parte da imprensa vinha contribuindo para "animar a revolta com publicações inconvenientes [...] constituindo elemento de perturbação e alarma em prejuízo da ação do governo e da tranquilidade pública [...]” (ibidem, p.121-4).

24 Freire posteriormente comenta que a cidade de Niterói não havia sido contemplada pelos "interesses superiores de humanidade" tremulados pelos representantes da diplomacia europeia quanto ao Rio de Janeiro, permitindo que o bombardeamento da cidade fosse legalizado por estes. Mais à frente, dirá Freire (1982, p.131-2,160) que tais "interesses superiores de humanidade" não incluíam bombardeios, mas somente o comércio. 
No sétimo capítulo de sua obra, Freire passa a historiar a atuação diplomática durante a primeira e segunda fases da Revolta. Esse capítulo foi construído como resposta a Joaquim Nabuco, que, como se verá adiante, defendeu a ideia de que o governo havia solicitado a intervenção estrangeira no conflito. A querela centrava-se na visita feita pelo contra-almirante Coelho Neto na manhã de 6 de setembro de 1893 a bordo do navio inglês presente na baía, comunicando os representantes europeus sobre o conflito. Amparado pelo relatório do Ministério da Marinha, Freire (1982, p.150) argumenta que Neto fora à embarcação somente para "comunicar a ocorrência, a fim de acautelarem-se e garantirem as comunicações de seus navios com a terra, evitando-se sinistros possíveis em vista da atitude dos navios revoltosos". Assim feito, o ministro das Relações Exteriores, João Felipe Pereira, redigiu uma carta no mesmo dia convidando os diplomatas estrangeiros para tratar dos meios de garantir os direitos dos cidadãos estrangeiros. Conjuntamente, os representantes de Portugal, França, Estados Unidos, Itália e Inglaterra enviaram nota recusando o alvitre, fato interpretado pelo governo como demonstração de indiferença ou até simpatia à revolta, pois chegaram a aceitar uma ordem emanada por Custódio de Melo de se retirarem de uma zona marítima na baía, reconhecendo-lhe autoridade. Somente deixaram a posição de indiferença após o bombardeio do dia 13 de setembro, quando solicitaram ao ministro das Relações Exteriores uma conferência com o mesmo objetivo da reunião convocada anteriormente pelo governo brasileiro.

Na segunda fase da Revolta, a ação da diplomacia estrangeira manteve um suspeito diálogo com os revoltosos, ao contrário do governo, que intermediava suas proposições com os próprios diplomatas - e Freire ressalta - "não para intervirem e sim para regularizarem as questões aduaneiras e do policiamento do porto". Avolumava-se, assim, o temor de que tais representantes passassem da simpatia a concessões efetivas aos amotinados, acrescido o fato de que os estrangeiros se propuseram a ser avisados das operações de guerra na baía e a cuidar da segurança nas operações do porto. Melo 
não concordou com a proposta, pois não haveria garantias de que tal acordo não seria violado pelo governo brasileiro. Freire (1982, p.172-3) relata que, entre outubro e novembro, as forças estrangeiras passaram a oscilar quanto à simpatia aos rebeldes e à neutralidade, ora justificando a intromissão na luta interna do país, ora clamando pela segurança de seus súditos.

A entrada de Saldanha da Gama no conflito, delimitando o início de sua terceira fase, agravou as tensões entre as partes e catalisou a intervenção estrangeira. Gama era o membro da Marinha com maior prestígio internacional à época e, segundo Freire, "não podia deixar de compreender que sua intervenção em favor da causa de seus camaradas importava em vitória imediata”. Ele assumia a chefia do conflito ao mesmo tempo que Custódio de Melo dirigia-se ao Sul do País com o fito de fortalecer e unir os dois movimentos que aconteciam. As ideias monarquistas que permeavam a Revolução Federalista comandada por Silveira Martins, somadas à divulgação do manifesto de Saldanha da Gama, conduziram os monarquistas ao êxtase. Martins e Gama, este ainda na neutralidade, comunicaram-se durante a Revolta da Armada, e Gama pedia ao federalista que autorizasse a nomeação de Eduardo Prado como representante dos revoltosos junto aos banqueiros alemães (Janotti, 1986, p.71-3). Para Freire (1982, p.188), Saldanha da Gama entendia, àquela altura, que a solução do conflito se daria somente por meio de medidas enérgicas, mas no seu próprio manifesto já incutia o desagrado em algumas fileiras republicanas da Armada:

A primeira palavra que se fez ouvir do novo chefe foi a necessidade de repor as coisas do país no pé em que se achavam a 15 de novembro, no manifesto restaurador que repercutir nas próprias fileiras dos revolucionários, produzindo rompimento de solidariedade e protestos, que fizeram com que o almirante Saldanha se retratasse em um segundo manifesto, em que se apresenta como republicano parlamentarista. [...] Foi com alarde e estrondo que o contra-almirante iniciou seu comando revolucionário. 
As críticas ao posicionamento de Saldanha fizeram aparecer manifestações em prol da República em diversos Estados do País. No Distrito Federal, falou-se que os "crimes e atrocidades cometidas pelos rebeldes" não seriam tolerados, dando apoio efetivo a Floriano Peixoto. Em Minas Gerais, criticou-se o militarismo como meio de resolução de problemas políticos da nação, já que sua superação não viria por meio de conflitos reivindicatórios de autoridade pela força, pelo contrário, eles deveriam vir por meio das leis. No Mato Grosso, em São Paulo, no Rio Grande do Norte, na Paraíba, no Amazonas e em Pernambuco, sobressaía no discurso dos governadores (aliados de Floriano Peixoto) a defesa da República e de Floriano Peixoto em detrimento da dinastia incompatível com a índole democrática do povo brasileiro: a de Bragança (ibidem, p.189-91).

A ação de Gama após a publicação e recepção de seu manifesto foi dura: queria forçar o fechamento do comércio, colocando o "governo em posição embaraçosa", levando-o a agir militarmente. Entre dezembro de 1893 e janeiro de 1894, as lutas entre as partes se intensificaram, cabendo aos rebeldes diversas vitórias, interpretadas pela diplomacia presente na capital como um sinal da derrota iminente do governo brasileiro. Impedidos de descarregar suas mercadorias, representantes estrangeiros forçaram o posicionamento do Brasil, que transferiu para outros locais as operações dessa natureza, descontentando principalmente os norte-americanos, em fatos narrados por Salvador de Mendonça. Na tentativa de atracar e descarregar suas mercadorias, a esquadra dos Estados Unidos teve de armar seus canhões contra os rebeldes, que tentaram proibir a ação atirando contra as embarcações comandadas por Saldanha da Gama.

$\mathrm{O}$ atrito entre as duas esquadras desprestigiou sobremaneira a revolta, que não pode anular a intimação [do] almirante Benham, colocando-se as esquadras das outras nacionalidades na obrigação de proteger a carga dos vapores, não consentindo mais na apreensão. Isto deu em resultado realizar-se o serviço aduaneiro, porque todos os navios passaram a carregar e descarregar atracados aos trapiches, anulando-se assim o programa do almirante Saldanha (Freire, 1982, p.199). 
A ação de Benham, como já foi apresentada anteriormente, acabou por abater o moral dos rebeldes que combateram e bombardearam esporadicamente ao longo de janeiro e fevereiro de 1894. No Sul do País, a Revolução Federalista que havia agregado algumas vitórias passou a esmorecer, influenciando no conflito da capital federal. Do posto meridional, Custódio de Melo procurou organizar forças militares em terra para invadir o Rio de Janeiro, sem sucesso, sendo bloqueadas pelas forças de São Paulo. O resultado colocado por Felisbelo Freire foi que Saldanha havia ficado só, "na baía do Rio de Janeiro, sem os auxílios do Sr. Melo e cercado pelas baterias e esquadra do governo, quando este anunciou a 12 de março o combate que lhe ofereceu". Saldanha não aceitou o combate, divulgou o pedido de capitulação - não aceito pelo governo - e se refugiou nos navios portugueses, facilitando o trabalho da esquadra organizada no estrangeiro. Terminava, assim, a Revolta, garantindo a Floriano Peixoto o exemplo de chefe de Estado que não arrefeceu em face de imposições revolucionárias (ibidem, p.218-9).

Analisando-se os argumentos apresentados até este ponto da obra de Freire, nota-se que a questão apresentada pelo conflito desdobrarase no plano interno e no externo. A fragilização das instituições republicanas que se encontravam desorganizadas (ver o exemplo na pasta de Relações Exteriores) e os embates entre os poderes Legislativo e Executivo acerca da noção de federação qualificavam a luta na capital federal como o ápice de tal situação política no campo interno. Para além dessa situação, de forma complementar, no plano externo a ação da diplomacia brasileira nos Estados Unidos procurou defender as ações de Floriano Peixoto e assim aproximar os dois países em um novo relacionamento inaugurado em 1889. Em todo o caso, a Revolta da Armada exerceu grande influência na organização política do Brasil com relação à participação das classes militares no poder e suas noções de como defender os interesses nacionais, matéria complexa que, àquela época, se reestruturava por causa da mudança do regime.

$\mathrm{O}$ argumento já apresentado de que os políticos (e os diplomatas) brasileiros priorizavam o elemento político em detrimento do econômico, ao contrário dos norte-americanos, fazia-se valer mais 
uma vez, ainda que o posicionamento brasileiro não significasse desinteresse pelo item colocado em segundo plano, porém era a boa saúde das relações políticas entre os dois países que poderia garantir uma possível intervenção contra os rebeldes e até mesmo países europeus que se colocassem ao lado dos adversários do governo de Floriano Peixoto. Ao historiar a ação diplomática na terceira fase da Revolta, Felisbelo Freire destaca que o ponto que mais agravou a "estabilidade" do conflito foi a ação de Saldanha da Gama quanto à proibição do desembarque de mercadorias no porto e do trabalho da alfândega. Tamanha gravidade da situação levou os representantes estrangeiros a uma reunião no dia 31 de dezembro de 1893, requisitando a renovação do acordo firmado em outubro, além de pedirem ao governo brasileiro que os avisasse de qualquer bombardeio aos rebeldes com 48 horas de antecedência. Na impossibilidade dessa atitude, vista com indignação pelo governo brasileiro, as tensões entre as parte se agravaram, ao passo que as rendas oriundas do porto diminuíram sensivelmente. ${ }^{25}$ Esses fatores contribuíram diretamente para a atuação da diplomacia brasileira nos Estados Unidos que fez agir o contra-almirante Benham e para a posterior capitulação dos rebeldes, que se asilaram em navios portugueses.

Sobre a ação de Benham, Felisbelo Freire se detém em algumas páginas para defender o argumento de que o governo brasileiro recusou toda e qualquer oferta de intervenção estrangeira para o término da Revolta, sendo a ação do comandante norte-americano a manifestação da indignação dos Estados Unidos quanto à paralisação das atividades comerciais no porto do Rio de Janeiro. Para o governo brasileiro, que não reconhecera os revoltosos como beligerantes, a ação norte-americana era mais uma contribuição para enfraquecer a esquadra rebelde, que entrava em janeiro de 1894 fortalecida.

Portanto, para Freire, a ação da esquadra norte-americana havia intercedido pela normalização do comércio internacional, não em

25 Até o dia 17 de dezembro, os rebeldes protegiam o desembarque das mercadorias importadas. Depois dessa data, passaram a confiscá-las, impossibilitando o diálogo e as negociações entre diplomatas com o governo brasileiro. 
nome do governo brasileiro e contra o movimento monarquista. Freire combatia nesse ponto as ideias de Joaquim Nabuco, que acreditava ter havido violação da soberania brasileira no conflito quando Benham disparou contra a armada rebelde. Segundo Freire, a violação da soberania brasileira ocorrera de fato quando os portugueses abrigaram os revoltosos capitulados em suas embarcações, recusando-se a entregá-los ao governo brasileiro. Para o governo brasileiro, o crime cometido pelos rebeldes era de pirataria, não um crime político, portanto não tinham direito ao asilo, ao contrário do que pensava o governo português, que, sob o comando de Augusto de Castilho, comprometeu-se a não desembarcar os asilados em território estrangeiro até que o impasse fosse resolvido. Ao contrário das ordens de Castilho, que fundeou seus navios no Rio da Prata, cerca de 250 asilados, incluindo Saldanha da Gama, que se juntou aos federalistas no Rio Grande do Sul, deixaram as embarcações. O desfecho de tal situação foi o rompimento das relações entre Brasil e Portugal em 13 de maio de 1894 (Heinsfeld, 2007, p.4).

A partir de outra perspectiva do conflito, certamente mais próxima - porém não declarada - da posição dos rebeldes, estava Joaquim Nabuco. Ele escrevera uma série de artigos para o Jornal do Comércio não com o fito de escrever a história da revolta de 6 de setembro, mas "contribuir para ela com a apreciação de um dos principais elementos da vitória do marechal Floriano Peixoto: a intervenção estrangeira" (Nabuco, 1939, p.7). Nesse sentido, a obra de Nabuco representa um recorte específico do conflito ao mesmo tempo que procura contrabalancear argumentos apresentados por Felisbelo Freire e outros indivíduos ligados ao campo político.

Para Nabuco, em setembro de 1893 o governo brasileiro e a cidade do Rio de Janeiro estavam completamente à mercê da Revolta e de seus canhões, restando apenas um recurso: a intervenção das esquadras estrangeiras. Consciente desse fato, o governo então solicitou tal intervenção, obtendo-a em outubro, quando o acordo fora assinado. Ainda em setembro, a visita do contra-almirante Coelho Neto, ao contrário do que defendia Felisbelo Freire, tinha por objetivo pedir o apoio moral dos representantes estrangeiros ao governo brasileiro 
para que fossem evitados bombardeios à cidade, encontrando hesitações até que o agravamento das hostilidades catalisasse a reunião do corpo diplomático internacional e a formulação das cláusulas do acordo (ibidem, p.13-5).

Segundo Nabuco, Floriano Peixoto não possuía motivos para recusar o acordo proposto pelas potências europeias ali presentes, pois, em meio às dificuldades em termos de armamentos, embarcações e munições em que se encontrava, toda ajuda seria útil. Na imprensa, os jornais brasileiros e estrangeiros discutiam a intervenção feita em nome dos "princípios superiores de humanidade": para o Paíz, a intervenção estrangeira, se não fora feita a pedido dos brasileiros, fora-a pelo governo, "oficialmente solicitada desde o primeiro momento". Jornais como o Rio News e o Brésil Républicain procuraram defender a ideia de que a inviolabilidade da soberania nacional na questão arvorada pelo governo e seus defensores não comportava a ação de 5 de outubro, na qual outros países agiam como intermediadores de um conflito interno do País.

Para Nabuco, o acordo de 5 de outubro concretizava a intervenção estrangeira requisitada pelo Brasil, pois o governo fez concessões profundas, como na retirada dos canhões que guarneciam as baterias na baía e na "organização" dos períodos do conflito, criando uma espécie de normalização que permitiu a estruturação da Esquadra Legal no exterior. Assim, a partir de outubro tem início a regulamentação do conflito, a qual o autor da obra coloca como uma "medida de humanidade", ou até mesmo uma "intervenção salvadora”, pois, a partir desse momento, Floriano Peixoto podia respirar livremente, visto que a posse militar do Rio de Janeiro estava-lhe garantida, não podendo ser disputada pelo lado do mar (ibidem, p.22-44). Joaquim Nabuco (1939, p.47-8) criticou duramente a assinatura do acordo em outubro de 1893:

O governo que recorre ao estrangeiro, para tirá-lo de uma grave dificuldade interna, sacrifica sempre a sua altivez e pode muitas vezes comprometer a soberania nacional. Há casos em que o socorro estranho em uma crise política não abate o país que o recebe. Esses casos 
são raros e sempre delicados. Há, porém, uma preliminar para eles: é que o socorro não seja pedido pelo governo. Desde que este precisa de força armada de outra nação para debelar uma revolta, reconhece a sua impotência, e é preferível que faça concessões razoáveis aos seus conterrâneos.

O acordo, amplamente favorável ao marechal Floriano Peixoto e feito em nome da proteção da cidade e de seu comércio, deu o tempo necessário ao governo para se reorganizar e atacar os rebeldes, ainda que alguns impedimentos das potências estrangeiras afetassem diretamente esses planos. Os representantes estrangeiros, estacionados nas águas da Baía de Guanabara, especificamente o inglês, o português e o alemão, não permitiram o desembarque de munições, armas e holofotes, que poderiam ser utilizados no conflito tanto pelo governo brasileiro ou quando confiscados pelos rebeldes, o que indiretamente deu força à diplomacia atuante nos Estados Unidos, local de onde veio a quase totalidade da nova esquadra do Brasil. Assim, a atuação dos norte-americanos em prol do governo brasileiro dava claros sinais de fortalecimento, principalmente quando o contraalmirante Stanton foi demitido por Grover Cleveland por não ter cumprimentado o governo legal e saudado a bandeira dos revoltosos. A imprensa norte-americana, conforme apresentada por Nabuco, interpretava o ato do presidente daquele país como uma prova da simpatia dos Estados Unidos pelo governo de Floriano Peixoto. De fato, o crescimento gradativo da esquadra norte-americana no Rio de Janeiro era outro sinal de que o governo de Washington estava decidido a intervir em favor da legalidade por causa da desconfiança ou do receio da preponderância europeia no Brasil (ibidem, p.58-72).

No ínterim entre o acordo de 5 de outubro, a entrada de Saldanha da Gama no lado dos rebeldes e a ação de Benham na baía, o governo brasileiro havia se aproveitado do modus vivendi para fortalecer suas baterias. Tal atitude significava a violação do acordo estabelecido, provocando Gama a se manifestar. Em nota de 28 de janeiro de 1894 , o chefe da esquadra rebelada apresentou argumentos que demonstravam estar o governo de Floriano Peixoto fortificando diversas áreas 
não militares da baía, incluindo locais religiosos, comprometendo o acordo e estimulando as hostilidades com os rebeldes. Finalizava a nota dizendo que, sob seu comando, a esquadra respeitaria o pacto firmado, porém responderia com veemência a qualquer agressão por parte das baterias da cidade sem aviso prévio. Para Nabuco, Saldanha não possuía a força que ostentava na nota, pois a intervenção havia - ainda que não declaradamente - arrefecido seus intentos, o que representava o quão importante fora a operação estrangeira nos rumos tomados pelo conflito, auxiliando o governo, comprometendo, porém, a soberania nacional: somente ela havia possibilitado a dissipação do conflito, que, do lado rebelde, agonizava após a ação de Benham.

De certo, fora humilhante para o governo a reunião cotidiana em nosso porto de um conselho superior de almirantes estrangeiros deferindo e indeferindo as queixas dos dois combatentes: resolvendo entre o si o que podiam tolerar e o que deviam proibir quer às forças legais quer às forças revoltosas; apreciando cada tiro segundo o interesse comercial estrangeiro; verificando donde partia a provocação para decidir se a repulsa não a teria por acaso excedido. Foi porém, este regime exclusivamente que tornou possível a fortificação dos morros sob grossos canhões da esquadra e possível o arrasamento de Villegaignon [...] (Nabuco, 1939, p.76).

A resposta ao apelo de Saldanha foi a ação de Benham, que chegou a atirar em direção aos navios rebelados. $\mathrm{O}$ governo brasileiro, por sua vez, aplaudiu a ação da esquadra americana. Nabuco comenta que o Paíz imprimiu em suas páginas um detalhado relato sobre a ação dos norte-americanos, e o nome do contra-almirante tornou-se referência aos inimigos da revolta. O que se seguiu foi a proposta de capitulação dos rebeldes, assinada por Saldanha em março de 1894. Ela continha o pedido de retirada para o estrangeiro dos oficiais sob garantia e guarda da nação portuguesa; a entrega de navios, fortalezas e materiais no pé em que se encontravam; e, por fim, pedia a restituição dos prisioneiros feitos pelo governo. Ape- 
sar de apoiado pelos representantes estrangeiros, o pedido não foi aceito pelo governo brasileiro, que atacou - conforme palavras de Nabuco - implacavelmente embarcações e rebeldes, que procuraram asilar-se nas naus portuguesas. Augusto de Castilho, comandante dessas embarcações, havia prometido asilo a cerca de setenta pessoas, mas, em meio ao desespero e temor da violência do governo, deu abrigo a mais de quinhentas (ibidem, p.80-7).

Joaquim Nabuco elogiou longamente a atitude do comandante português. Para ele, Castilho havia, desde o primeiro momento, avaliado devidamente a importância da intervenção estrangeira no conflito, sabendo que, caso contrário, a esquadra revoltada não teria sido forçada a pedir asilo em seus navios e que o acordo somente fora rompido pelo governo de Floriano Peixoto quando este se viu em condições de dispensar o auxílio internacional. Castilho havia sido fiel aos compromissos tomados em nome de seu país e fora apoiado pelo governo inglês, que recusou o pedido brasileiro de repatriação dos asilados (ibidem, p.90-5).

Nessa discussão a respeito do asilo o que sobressai é a facilidade com que o Ministério das Relações Exteriores presume que o mundo inteiro há de esquecer ou suspender de repente os princípios mais obrigatórios do Direito Internacional para atender a uma dificuldade momentânea do Brasil. Assim como para a repressão da revolta julgou-se de nenhuma consequência o abrir o governo mão do princípio de soberania para pedir e aceitar a intervenção estrangeira, submetendo-se às decisões de um conselho de comandantes estrangeiros encarregados de regular as condições do tiro, entendeu-se também que era legítimo sustentarmos para um efeito transitório as mais obsoletas teorias [...] as capitulações com o estrangeiro, quaisquer que fossem, pareciam preferíveis ao menor ato de tolerância para com os adversários políticos (ibidem, p.96-7).

De bloqueadores, os rebeldes passaram a bloqueados, tal era a expressão utilizada pelo ministro das Relações Exteriores, Cassiano do Nascimento. De fato, a situação invertera-se, e o Brasil não con- 
seguiu recuperar os asilados, que se dispersaram ou morreram em conflito no sul do país, caso do contra-almirante Saldanha da Gama.

Após dissertar sobre a Revolta da Armada, Joaquim Nabuco formula um retrospecto dos acontecimentos, comentando os pontos que considerava fundamentais para o desenvolvimento e a solução do conflito. A primeira das duas fases do conflito, segundo o autor, foi marcada pela intervenção estrangeira na formulação do modus vivendi na baía, compromisso respeitado pela esquadra rebelada e não pelo governo legal, que procurou se armar e comprar no exterior munição, embarcações e armas para a dissolução do conflito, e, quando concluiu tal operação, violou abertamente o acordo, atacando a partir da terra os revoltosos. Paralelamente, foi derrotado diversas vezes pelos rebeldes, chegando a mudar o ânimo internacional acerca de sua vitória. A entrada de Saldanha da Gama no conflito marcou o início de uma nova fase nas lutas, pois o contra-almirante impediu o desembarque de mercadorias no porto, fato que pressionou a intervenção dos Estados Unidos. A atitude dos norte-americanos no conflito foi amparada pelo discurso propagado pelo governo brasileiro que o movimento rebelde camuflava planos para a restauração da Monarquia no País, fragmentando as opiniões favoráveis à causa dos rebeldes.

O movimento no Rio de Janeiro não pode ser entendido sem a conexão com o conflito federalista na Região Sul do País, que tornou mais complexa a luta dos marinheiros na capital federal. Muitos dos rebeldes eram republicanos, e a coloração monarquista que os federalistas emplacavam em seu movimento não permitia a união de interesses e o conseguinte fortalecimento das reivindicações. $\mathrm{O}$ cerne do conflito para Joaquim Nabuco, a despeito das questões internas que o fundamentam, foi a intervenção estrangeira. Para ele, o elemento estrangeiro não pode ser o juiz da legitimidade de um movimento insurrecional, pois a soberania não pertence a um governo específico, mas sim às nações, não podendo envolver-se em questões de ordem interna do país. As condições do conflito, tal como foi negociado, foram invertidas. Era o elemento estrangeiro que garantia a proteção do País, incapaz de se defender. Nesse sentido, a 
responsabilidade pela intervenção cabia ao governo brasileiro, pois fora deliberação sua requisitar tal ação. Era preferível, portanto, fazer concessões aos adversários a receber auxílio material do estrangeiro (ibidem, p.107-44).

Um episódio posterior ao conflito haveria de inflamar os argumentos de Nabuco: o governo brasileiro havia mandado cunhar moedas com as faces dos presidentes do Brasil e dos Estados Unidos em homenagem à intervenção destes em prol da manutenção da República no País. Assim,

Que mostra essa união simbólica de dois presidentes na medalha de uma guerra civil senão que no próprio instinto de suscetibilidade nacional houve um profundo desequilíbrio, uma confiança crédula no apoio desinteressado do estrangeiro, um impulso para envolvê-lo em nossas questões internas? - o que tudo é ignorar que a proteção, a intervenção, o socorro, é sempre na história o modo por que primeiro se projeta sobre um Estado independente a sombra do protetorado (ibidem, p.149).

Por fim, Nabuco conclui sua obra dizendo que Floriano Peixoto ficaria lembrado como aquele que matou o germe da restauração monárquica e "salvou" a República, graças à interferência do jacobinismo, nada mais do que um "pastiche histórico". Nabuco não duvidava de que o conflito fosse causado, sobretudo, pela "política local do Marechal Floriano Peixoto, tratando de colocar no poder os partidários do golpe de 3 de novembro [de 1891]" e que o maior perigo que a República corria com a Revolta da Armada não era a restauração monárquica, mas o perigo do "esfacelamento militar pelo rompimento das duas classes que em nome da nação fizeram o 15 de novembro". Portanto, ele atribuía ao elemento militar - as causas nomeadas "sociais" por Felisbelo Freire - a origem do conflito, além de nutrir certa simpatia ao movimento monarquista.

A Revolta fora feita, de ambos os lados, em nome da República, mas fora camuflada por interesses de segmentos do Exército e da Marinha na disputa pelo poder político do País. Nabuco não contestava 
a ação de Floriano Peixoto na defesa de sua autoridade, porém não aceitava a apelação ao estrangeiro como recurso para dissipar o conflito, que após seu término teve muitos prisioneiros fuzilados clandestinamente. Ironicamente, terminava dizendo que "a República brasileira devia defender-se como a República norte-americana pelos meios de que dispõem usualmente os governos livres, respeitando a civilização e humanidade do País” (ibidem, p.158-67).

Os anos subsequentes foram paradigmáticos em face do conflito entre Armada e Exército, apresentando uma ruptura e uma continuidade. Internamente, o elemento civil vencera, com Prudente de Moraes na presidência do País, secundando o militarismo. Externamente, a aproximação com os Estados Unidos crescia a passos largos, aprimorando o relacionamento inaugurado em 1889 na Conferência Interamericana.

Sobre as críticas acerca da intervenção norte-americana na Revolta da Armada, não ficou indiferente Salvador de Mendonça. No ofício confidencial ao governo brasileiro em que narrava as atividades da representação diplomática durante o conflito, Mendonça terminava dizendo que a imprensa norte-americana considerava sua intervenção como fundamental para os rumos do conflito, tornando-o "credor da mais alta recompensa que a pátria pode lhe dar". Nesse sentido, não era exagerado dizer que a Revolta também fora debelada a partir das decisões negociadas em Washington (Bandeira, 1973, p.144-5; Azevedo, 1971, p.276). ${ }^{26}$

Para os entusiastas da americanização do Brasil, como Salvador de Mendonça era, a intervenção norte-americana na Revolta era a demonstração do apoio de uma nação amiga à outra e, para tanto, não tinha lugar o argumento de que a soberania brasileira fora arranhada, até porque os rebeldes capitularam, em março de 1894,

26 Nos Estados Unidos, o contra-almirante Benham foi homenageado com um banquete, ocasião na qual seu procedimento foi elogiado para "convencer aqueles amigos [do Brasil] que a nação americana nada perdeu ainda do seu prestígio”. Benham agradeceu dizendo que a amizade entre os dois países se baseava "no respeito e, talvez, em alguma coisa mais". Tal declaração, segundo Bandeira (1973), provocou uma "tempestade de aplausos e gargalhadas". 
um mês e meio após a ação da esquadra norte-americana, cabendo à formada pelo governo brasileiro durante o conflito bombardear as embarcações que estavam em sua posse. Uma década mais tarde, Salvador de Mendonça (1913, p.199) diria sobre o conflito que "o ponto único a resolver era simples: verificar de que lado estava a lei e o interesse supremo da República. Feita esta verificação, minha linha de proceder estava traçada, e seguia meu caminho sem hesitações". Para o diplomata, o Brasil precisava aproveitar-se do apoio norteamericano para não fazer perigar suas instituições no momento em que elas sofriam o mais duro revés, justificando sua atuação em prol da intervenção estrangeira, que também não partira de uma convicção pessoal, mas de uma deliberação do governo brasileiro, que pedira a ele que fizesse o possível para evitar o reconhecimento como beligerantes dos revoltosos nos Estados Unidos, obtendo a posterior intervenção de Benham (Azevedo, 1971, p.260).

Tenho sido acusado mais de uma vez de haver ofendido a soberania nacional com o obter essa intervenção da divisão norte-americana contra navios que arvoravam a bandeira nacional, intervenção que deu tão fundo golpe na revolta. A proteção dada à descarga de navios mercantes norte-americanos dentro deste porto, e a intimação ao navio revoltoso que procurou manter o bloqueio, foram perfeitamente legítimas (Mendonça, 1913, p.208-9).

Clodoaldo Bueno (1995, p.189-90) aponta que a política inaugurada pelo Brasil sob o regime republicano, de franca aproximação com os Estados Unidos, era assinalada na Revolta da Armada como mais uma inversão de prioridades estratégicas: o Brasil, tal como no tratado de 1891, colocava no primeiro plano seus interesses políticos, secundando os econômicos, ao contrário dos Estados Unidos, que intervieram no conflito não a partir deste ou daquele regime político, tanto é que hesitaram quando os rebeldes sinalizaram a vitória no final de 1893, mas a partir de preferências de ordem material, ou seja, pelo funcionamento normal das atividades comerciais. Ao fim, a ação norte-americana gerou críticas e contestação ao governo brasileiro e à 
diplomacia, que em 1894, início do mandato do primeiro presidente civil, sinalizava substituições no quadro de funcionários investidos no ano de 1889 caracterizado pelo militarismo.

O governo de Prudente de Moraes foi posto à prova apenas em duas ocasiões representativas: no conflito em Canudos, que colocou em xeque o republicanismo dos civis no poder e avolumou as críticas dos jacobinos, e na tentativa de assassinato do presidente, que envolveu membros de seu gabinete e do Partido Republicano Federal. A cisão no partido entre "gliceristas", partidários de Francisco Glicério, apoiado por segmentos do Exército, ${ }^{27}$ e "prudentistas", amparados pela elite cafeeira e republicanos históricos, culminou com processo e prisão dos envolvidos, expondo que o regime brasileiro ainda não havia encontrado a rotina institucional necessária para o bom andamento do campo político, a partir do qual eram irrigados o econômico e o social (Lessa, 1988, p.87-90; Carone, 1971a, p.152-68).

Entre 1894 e 1898, nos Estados Unidos, não houve no terreno dos acontecimentos algo em que Salvador de Mendonça tivesse que intervir em prol do apoio daquele país pelo Brasil como nos anos iniciais do regime republicano, indicando que novas tentativas de acomodar o sistema político internamente, ou seja, nas relações entre os poderes e entre a Federação e os Estados, vinham sendo experimentadas, representando de fato um período de transição na política interna com reflexos na política exterior (Queiroz, 1986, p.258).

Sua ação restringiu-se a reativar junto à Secretária de Estado norte-americana a ideia da criação de mais um tratado de aliança americana, ideias narradas em longo ofício confidencial de 24 de outubro de 1895 (cf. Azevedo, 1971, p.291-7). Nele, Salvador de Mendonça fazia uma síntese do relacionamento dos dois países nos últimos anos para justificar a oportunidade de os dois países se juntarem na empreitada não aproveitada pelos demais nas deliberações da I Conferência Interamericana em 1889. Como "regra geral", o diplomata apoiava-se no monarquismo e nos interesses europeus

27 Segmentos que não eram aliados dos federalistas e dos participantes da Revolta da Armada. 
contra os países americanos para firmar tal acordo, pois "o despeito e a animadversão da maioria das Cortes da Europa contra a República brasileira tem crescido pari passu com a simpatia e a amizade que por nós tem mostrado a União norte-americana”. Também narrava que o espírito de tal aliança continental fora gestado e encorajado por ele e James Blaine, que não viveu para cumprir seus ideais. Segundo Salvador de Mendonça, Blaine previra que a derrocada do último trono na América provocaria reações adversas dos europeus e, para tanto, seria de grande necessidade a formulação de uma liga americana contra as pretensões europeias no continente, defendendo-se das agressões monárquicas "e conquistar a Europa para a República com o exemplo da nossa prosperidade e grandeza sob o regime da democracia”. A situação encontrou solavancos com a morte de Blaine, substituído por Walter Gresham, menos entusiasmado com uma possível iniciativa integracionista. A essa altura, Salvador de Mendonça ponderava que a Doutrina Monroe já se mostrava insuficiente para atender aos interesses dos países americanos sintonizados com o governo de Washington, surgindo dessa configuração a institucionalização de um tribunal arbitral continental. A substituição de Gresham, que falecera em 1894, por Richard Olney não fez progredir as negociações para o acordo de aliança. Nas diversas reuniões que Salvador de Mendonça travara com o secretário de Estado norte-americano, este se esquivava de qualquer atitude declaradamente antieuropeia, argumentando que o fito da Inglaterra, por exemplo,

[...] era evidentemente por a prova a longanimidade do governo dos Estados Unidos e expô-lo ao risco, ou abandonar a sua política internacional e ver-se coberto de ridículo, ou defendê-la e incorrer na pecha de influência indébita nos negócios das demais nações americanas. [...] Se os Estados Unidos, prosseguiu mais uma vez, convidassem as nações do continente para um congresso, suas intenções seriam imediatamente deturpadas e o seu interesse pela independência e bem estar das repúblicas latinas seria logo à conta de novo plano para dominá-las (cf. Azevedo, 1971, p.291-7). 
A postura de Olney, com o que autoriza dizer a leitura do ofício do diplomata brasileiro, era de que os Estados Unidos não convocariam ou organizariam certame com bandeira continental naquele momento, ainda que dele viessem participar caso fossem convidados. $\mathrm{O}$ norte-americano acreditava que os Estados Unidos eram capazes de, isoladamente, cuidar de seus interesses conflituosos com a Europa sem envolver países americanos, que poderiam ser lesados à custa de querelas de outrem. Olney somente era a favor da defesa tácita da Doutrina Monroe pelos países americanos, postura que facilitaria o entendimento e apaziguaria os setores inimigos dela na América e na Europa.

A correspondência de Salvador de Mendonça atrairia atenções em 1897, quando uma nova lei de tarifas foi aprovada nos Estados Unidos e nomeada de tarifa "Dingley", em detrimento da antiga "MacKinley", em vigor até o momento. A nova lei previa que produtos importados dos países americanos pelos Estados Unidos seriam tabelados novamente, forçando a assinatura de acordos bilaterais de comércio a fim de buscar a isenção dos produtos envolvidos ou sua sobretaxação. Em ofício de 3 de abril de 1897 (ibidem, p.307-8), ele relatava que, em relação ao acordo assinado em 1891,

[... é impossível desconhecer que as circunstâncias estão mudadas e que fora de mau aviso recomendar a renovação do convênio aduaneiro nas bases oferecidas pelo projeto atual de tarifa, em que o termo "reciprocidade" com razão pode ser substituído pelo termo represália. Somos ameaçados com a imposição de direitos pesados sobre os nossos produtos de exportação, caso nos recusemos a celebrar novo convênio, mas se o celebrarmos, a compensação que nos oferecem é quase que ilusória.

A situação foi discutida entre os representantes dos principais países produtores de café no continente, pois este seria o produto diretamente afetado com a nova tarifa, ao passo que, após reunião entre eles, foi decidido em nota oficial que o que fora proposto não poderia ser qualificado de reciprocidade, mas de represálias, ainda mais que nenhuma das nações americanas havia dado mostras de hostilidade 
ao comércio dos Estados Unidos, e os produtos contemplados em uma possível isenção de tarifas já o possuíam, anulando qualquer benefício apresentado. Assim, recomendavam

[...] aos seus respectivos governos que não celebrem convênios de reciprocidade sobre a base da citada tarifa, sem que contudo esta indicação abranja o caso de os Estados Unidos proporem às nações latino-americanas a celebração de tratados sobre a base de verdadeira reciprocidade, com vantagens equivalentes e recíprocas. ${ }^{28}$

Em cabograma dirigido ao Ministério das Relações Exteriores, em 24 de julho de 1897, Salvador de Mendonça sinalizava que os norte-americanos alterariam as condições impostas pela tarifa Dingley, dando tempo suficiente ao governo brasileiro para o estudo da questão e, assim, oferecer a probabilidade de assinatura de um novo acordo sem o perigo da imposição de taxas (ibidem, p.314). A questão fora estudada pelo governo brasileiro, que a rejeitou por, ainda que reformulada, ser desvantajosa ao País.

Em março do ano seguinte, Salvador de Mendonça foi removido como enviado extraordinário e ministro plenipotenciário de primeira classe de Washington para Lisboa, cabendo ao Congresso do Brasil aprovar a ação do Ministério das Relações Exteriores. Na entrega de sua carta revocatória, ele elogiou o governo e o povo dos Estados Unidos, para ele a referência para todo o continente. No País desde 1875, Salvador de Mendonça admirava o crescimento material e político norte-americano, desejando que o progresso e a influência que ele exercia perante os países do continente fossem utilizados em prol da paz e do respeito à lei. Dizia que:

Foi minha aspiração, antes de deixar vosso país, sentar-me ainda uma vez ao redor da mesa em que todas as Repúblicas Americanas restabelecessem em base mais sólida o acordo esboçado no tratado não ratificado de 28 de abril de 1890, distribuindo a responsabilidade

28 Nota anexada ao ofício de 3 de abril de 1897, datado de 2 de abril de 1897 (cf. Azevedo, 1971, p.309-10). 
da política de Monroe pelos signatários do pacto, conforme é devido ao seu caráter soberano. [...] Aonde quer que meu dever para com a pátria me chame, posso assegurar-vos que meu coração e minhas simpatias estarão com vosso nobre povo e com o porta-estandarte da América republicana que está estendendo os postos avançados da liberdade humana até dentro das últimas trincheiras do passado (Mendonça, 1913, p.222-3).

Em resposta ao diplomata, William McKlinley, presidente dos Estados Unidos, agradecia as palavras do brasileiro, dizendo-lhe que o governo do Brasil certamente colheria por muito tempo os frutos de sua dedicação à causa "do governo do povo para o povo e de que as bênçãos da paz, do progresso e da abundância” lhes estariam sempre reservadas (Mendonça, 1913, p.225).

A imprensa norte-americana publicou vários artigos sobre a remoção de Salvador de Mendonça. Para o Washington Post, Mendonça havia sido um "operário industrioso" na obra de consolidação das relações entre os Estados Unidos e o Brasil, e sua obra não seria abandonada com sua transferência para a Europa, pois seus esforços haviam de ser indeléveis, dada a profundidade de suas negociações. $\mathrm{O}$ The New York Times também elogiou a carreira do diplomata, especialmente sua intervenção em prol do término do conflito entre 1893 e 1894 no Brasil, considerando tal ação como "o maior serviço" que um ministro poderia ter prestado a sua pátria (ibidem, p.233-44). ${ }^{29}$

\section{Diplomacia e política no nascimento da República brasileira}

Apesar de já se encontrar em Lisboa, o Congresso brasileiro não aprovou a transferência de Salvador de Mendonça para o posto,

29 Outros jornais, como o Sun e Evening Post, também relataram a saída de Mendonça dos Estados Unidos, lembrando principalmente de sua ação na Revolta da Armada. 
exonerando-o em 15 de setembro de 1898. O colega de trabalho de Salvador de Mendonça em Washington, Manuel de Oliveira Lima, entre 1896 e 1898, elogiou-o intensamente em seu livro de memórias, dizendo que o diplomata era dotado de um faro inigualável, pois havia conseguido um prestígio no campo político norte-americano que nenhum representante brasileiro tinha adquirido até então. Para Oliveira Lima, a transferência malsucedida de Salvador de Mendonça para Lisboa ficara a cargo do cônsul Fontoura Xavier, "obcecado pela ambição de ser ministro". Xavier servia com má vontade a Dionísio Cerqueira, ministro das Relações Exteriores de Prudente de Moraes, com o fito de obter a demissão de Salvador, a quem julgava proteger mais os interesses norte-americanos do que os brasileiros, formulando para isso convenções comerciais. ${ }^{30}$

Pesaram na exoneração as críticas sobre a atuação de Salvador de Mendonça desde 1889, especialmente durante a Revolta da Armada e sua condição de saúde, que se agravara em razão de um problema na visão, dificultando a leitura e a escrita (Lima, 1937, p.135-60). Cabe ressaltar a importância estratégica que a legação de Washington possuía para o Brasil, centralizando interesses econômicos e políticos do País nos Estados Unidos e o tempo de permanência do diplomata naquela capital, ${ }^{31}$ que certamente provocava a cobiça de outros diplomatas e expunha quão significativa era a legação naquela cidade.

Para Teresa Malatian (2001, p.119), a trama que culminou com a remoção de Salvador de Mendonça estava ligada ao seu envolvimento direto pela legalidade republicana e pela consolidação do regime, entrando em conflito aberto com os monarquistas durante a Revolta da Armada: "Ao garantir a República, Salvador de Men-

$30 \mathrm{Na}$ Biblioteca Nacional pode ser encontrada uma carta de Fontoura Xavier a Salvador de Mendonça datada de 9 de junho de 1887, quando ambos se encontravam nos Estados Unidos representando o Brasil. Ela aborda as convicções republicanas de Mendonça, tido por idealista. Segundo Xavier, "pois cá entre nós, por mais yankee que você possa ser, será sempre um exilado da luz, um nostálgico do ideal republicano" (seção de manuscritos, I-4, 22,8).

31 Antes de oficializar-se como diplomata em Washington, Salvador de Mendonça era representante do Brasil em Nova York. 
donça perdera o apoio de importantes forças políticas, que passaram a hostilizá-lo e acabaram conseguindo sua remoção de Washington e sua exoneração [...]".

Os anos que seguiram a exoneração foram de dificuldades financeiras advindas da ausência de emprego e das más condições de saúde, além das diversas visitas a ministros como Rio Branco, da pasta de Relações Exteriores, com o fito de ser colocado em disponibilidade. Em carta ao então presidente Campos Sales, Salvador de Mendonça expôs suas ideias acerca do cenário internacional e dos perigos que o crescimento norte-americano poderia trazer ao País, notadamente uma demonstração de que ainda se mantinha atento ao ofício.

Aos 60 anos, dos quais os últimos 26 foram quase todos passados em contato com esse povo e Governo, não tenho licença de ser visionário. [...] Nas mãos das Repúblicas Latinas está a escolha do modo por que esse encontro se tem de dar: por infiltração ou por inundação. Se por erro de política, nós outros latinos assumirmos atitude hostil, e, com nossos próprios receios começarmos a dar asas e a sugerir ambições porventura ainda não despertadas e cuja realização ainda não é necessária e oportuna, quando chegar seu tempo, achar-nos-emos todos diante de uma força avassaladora, a que nunca poderemos oferecer barreiras eficazes: a inundação virá poderosa e inelutável. Se porém, iniciarmos, ou melhor, prosseguirmos na obra de paz e boa harmonia, que durante nove anos mantive com a firmeza de convicção estar prestando ao Brasil o melhor serviço que podia prestar, se conseguirmos criar um tribunal arbitral americano, no qual cada nação do continente tenha voto igual e nele se dirimam todos os pleitos e se resolvam todas as diferenças, - tribunal que em futuro não remoto lançará as bases da grande Dieta Continental, onde só terão assento as nações sobreviventes; se, por tais processos, que não requerem exércitos ou armadas, mas diplomacia hábil e patriotismo esclarecido e muito senso prático, conseguirmos a grande obra de canalização, pela qual nos venham, em tempo próprio, capitais, braços, máquinas - e por que não dizê-lo? - a boa lição republicana, o respeito à lei e prática da verdade democrática, o contato se dará 
sem abalo, gradualmente, reguladamente, e essa infiltração só nos pode ser benéfica (Mendonça, 1960, p.229-30).

Com a chegada de Rodrigues Alves à presidência da República em 1903, Salvador de Mendonça conseguiu a promulgação do decreto que o colocou de volta no corpo diplomático em 10 de setembro do mesmo ano (Mendonça, 1960, p.245). ${ }^{32}$

Até 1913, quando faleceu, Salvador de Mendonça não voltou a exercer, em consulado ou representação no exterior, a função de diplomata do Brasil. Amargurado com tal posição, reuniu meses antes diversos artigos de sua autoria publicados na imprensa do Rio de Janeiro a fim de esclarecer à opinião pública sua trajetória. Para isso, não poupou críticas àqueles que naquele momento comandavam a política externa brasileira: Rio Branco, ministro, e Joaquim Nabuco, o primeiro embaixador do Brasil nos Estados Unidos. Salvador de Mendonça (1913, p.247-55) sentia-se injustiçado com a postura considerada inédita pelo governo brasileiro dada ao relacionamento entre os dois países e reivindicava a inauguração do período de aproximação entre eles:

O fito principal da sua publicação [da obra] foi mostrar o Estado real dessas relações ao tempo em que o golpe traiçoeiro do governo da República me arredou da Legação de Washington [...] Quando, pois, o barão do Rio Branco mandou o Sr. Joaquim Nabuco descobrir a América do Norte, ela já estava descoberta, medida e demarcada. $\mathrm{O}$ barão do Rio Branco teve sempre a sina desde os anos da mocidade em que frequentou a Alcazar Fluminense, de andar arrombando portas abertas. [...] Joaquim Nabuco vivia a falar da ideia americana, da paz americana [...] que ideia, que plano, que projeto, que negociações concebeu ou pôs em andamento nos anos de embaixada?

32 Salvador manteve correspondência regular com Rio Branco para tratar de sua reintegração ao corpo diplomático. O próprio Rio Branco era favorável à anulação do decreto que havia exonerado Mendonça em 1898, pois, por causa do tempo que ocupava o cargo, poderia aposentar-se ou se colocar em disponibilidade. 
Em 1913, a situação internacional era bastante diferente da vivenciada por Salvador de Mendonça no período em que trabalhou pelo governo brasileiro. Sob a inevitável presença norte-americana no Brasil e no resto do mundo, o diplomata já aposentado (conseguira em 1911) percebia que o tempo era de fastígio do pan-americanismo como prática ideológica e que gerava temores quanto a qualquer tipo de interesse dos Estados Unidos no restante da América:

As incertezas do futuro, que ainda nos ameaçam, requerem na situação presente a harmonia e o bom senso de todos os brasileiros. É preciso que se inicie desde já uma política generosa e de vistas largas, quer no interior, que no exterior. [...] Para que a América possa vir a ser para a Humanidade, é indispensável que comece por ser para os americanos, mas não só os do norte, como os de todo o continente. [...] É preciso que nós outros sul-americanos iniciemos desde já a política de aliança, não só do A.B.C., mas do alfabeto inteiro [...] É esta a hora de agirmos (Mendonça, 1913, p.261, 263, 266).

Salvador de Mendonça viveu em um período de transição política e ideológica no contexto nacional e internacional. Foi um dos atores principais no palco dessas transformações, agindo em meio a inúmeras turbulências internas no Brasil, e em contrapartida recebeu as críticas decorrentes da ausência de um planejamento eficaz para a política externa, que se voltava acentuadamente para os Estados Unidos com o advento da República, daí a busca por reconhecimento do regime, a assinatura de acordos comerciais pela intervenção na Revolta da Armada, enfim, em um entendimento e aproximação que tornavam unívocas as ideias de "republicanizar-se" e "americanizar-se". Não era por acaso que a Constituição brasileira, formulada em grande medida por Rui Barbosa, fosse inspirada na Carta constitucional norte-americana.

Nas ideias de Ricardo Seitenfus (1994, p.31-42), a política externa deve basear-se em três pilares fundamentais: a concepção, a prospecção e a execução. O bom funcionamento dessas ações está submetido a uma série de condicionantes, como a estabilidade interna 
de um país e a profissionalização do serviço diplomático. Se analisados os primeiros anos do regime republicano no Brasil, pode-se afirmar que não havia estabilidade interna suficiente inclusive para a formulação de planos e diretrizes em curto prazo, ainda que fosse herdado do Segundo Reinado um quadro volumoso de diplomatas e representantes no exterior. Mas o serviço ainda passaria por reformas para sua republicanização durante a primeira metade da década de 1890, complicando sua atuação. Nesse sentido, ficavam seriamente comprometidos os pilares da política externa do País no período, engendrando as tão divulgadas críticas à aproximação com os Estados Unidos, na ilusão com o comércio bilateral e na intervenção militar em uma questão doméstica.

A romantização e a escassa racionalização das ações da política externa do País perante os Estados Unidos foram caracterizadas pelo entusiasmo e tornaram polêmica a atuação diplomática de Salvador de Mendonça. Considerando tal postura, Clodoaldo Bueno (2007, p.90) entende que a presença dessas atitudes pode prejudicar seriamente a condução da política externa de um país, revelando certa inexperiência no campo das relações internacionais.

Em meio a tantas mudanças no campo político, cabe evocar o que Berstein (1998, p.353-5) conceitua como "cultura política”, figurando

No quadro de normas e valores que determinam a representação que uma sociedade faz de si. [...] Corresponde às respostas dadas a uma sociedade face aos grandes problemas e às crises de sua história, respostas com fundamento bastante para que se inscrevam na duração e atravessem as gerações.

Nesse sentido, quando se analisa a organização do Brasil e de sua diplomacia, aqui representada por Salvador de Mendonça na última década do século XIX, compreende-se que a republicanização, transfigurada em americanização do Estado, foi a tradução de um processo de construção de uma cultura política específica, na qual os valores fundamentais estavam ancorados na maior potência americana: 
os Estados Unidos, que se desenvolviam rumo ao posto de maior potência global no século XX. A construção dessa cultura política fora feita por atores das mais diversas tendências políticas, pois o republicanismo não era uma ideologia que cantava univocamente. Composta pelos militares e pelos civis, e entendida como uma visão de mundo atrelada ao campo político, foi explicitamente projetada no exterior, expondo que há uma grande porosidade entre a política interna e a política externa, sendo a diplomacia algo fundamental nesse processo.

Justapondo-se tal afirmação com a trajetória de Salvador de Mendonça, apreende-se que a americanização foi o sintoma, a característica e a prática mais difundida dos primeiros anos da República brasileira, na correlação política interna e externa, tanto que o advento do primeiro governo civil no País e o princípio de certa rotinização institucional retiraram do posto um diplomata há quase um quarto de século nos Estados Unidos. A prática política subsequente não seria feita a partir do vazio e teve suas continuidades e rupturas baseadas fundamentalmente na diplomacia da americanização, na qual Salvador de Mendonça formou um paradigma tanto pelo lado dos elogios quanto pelas críticas. 


\section{Considerações finaIS}

Os primeiros sopros de vida do regime republicano no Brasil foram executados com muita dificuldade. A partir de novembro de 1889, a procura pela organização política e econômica, preceitos comuns a qualquer Estado moderno, passou - peculiarmente - a fazer parte da agenda do Brasil, que via suas estruturas construídas há quase um século serem profundamente abaladas por um movimento heterogêneo e sem plataforma política sólida. A ausência de respostas por parte dos recém-instalados no poder para o futuro imediato chegava a se sobrepor à discordância política, tornando cada vez mais complexo o esforço organizatório.

Nesse sentido, a política interna do País estava seriamente comprometida. Assim foram as presidências militares da República, de Deodoro da Fonseca e Floriano Peixoto, as quais tiveram por característica a demissão de indivíduos por causa de querelas corporativas e da utilização da força na repressão às contestações feitas a suas administrações. A ausência de uma "rotina institucional" não permitia a pacificação dos diversos grupos que aspiravam ao poder, multiplicando conflitos internos e relegando ao segundo plano os interesses do País no âmbito coletivo. A transição dos governos militares ao domínio civil, inaugurada por Prudente de Moraes, ainda que tenha sinalizado relativo "respeito" pelas instituições 
republicanas por causa da transição via eleições, logo foi assolada por movimentos internos de contestação ao presidente e ao grupo econômico com o qual se vinculava.

Dessa forma, o entendimento do período de turbulência compreendido entre 1889 e 1898, quando termina o mandato de Prudente de Moraes, não pode ser feito de forma isolada dos acontecimentos no plano externo, certame onde são aplicadas as diretrizes da política exterior de um país. A política externa pode ser tomada como a expressão dos interesses nacionais tanto no campo político quanto no econômico, mostrando-se eficaz na clarificação e resolução de problemas e dificuldades em curto e longo prazos.

Conforme se procurou expor, ela foi determinante na construção de um novo comportamento político brasileiro, inaugurado em 1870 e posto em prática a partir de 1889. Esse comportamento político aproveitava-se do aspecto geográfico e político que a palavra "América” possuía à época: a ideia de República, nos moldes do paradigma continental, os Estados Unidos. Efetivamente, por mais díspar que fosse o grupo que assumia o governo em novembro de 1889, ideias como essas foram constantes no trato com os países americanos e europeus, estes últimos que referenciavam o campo político e cultural do Brasil no período monárquico.

Dessa forma, buscou-se uma íntima aproximação com os Estados Unidos por meio da diplomacia, certamente com o fito de obter reconhecimento e blindar internacionalmente o regime político proclamado, além de, no plano interno, suprir as lacunas abertas pela inexperiência administrativa e burocrática.

A carreira de Salvador de Mendonça desdobrou-se nesse cenário de gestação de um novo comportamento político. Em um primeiro momento como publicista, Mendonça foi ativo defensor da aproximação com os norte-americanos, sendo coautor das conhecidas linhas do Manifesto Republicano de 1870, e posteriormente, já no ofício de diplomata nos Estados Unidos, procurou conduzir as ações do Brasil ali no sentido de intensificar as relações comerciais. Sob o signo da República, o estreitamento dessas relações passou também ao campo político. 
A Conferência Internacional Americana, realizada em Washington entre 1889-1890, foi paradigmática, pois ocorreu paralelamente à mudança de regime no Brasil, que ao longo de todo o século XIX recusou-se a participar de iniciativas que visassem à maior integração com os países americanos, vistos com desconfiança (recíproca) perante os interesses imperiais.

A peculiaridade do Brasil em seu continente no momento em que se iniciava a Conferência dava lugar a "um panorama uniforme de Repúblicas”, conforme palavras do próprio Salvador de Mendonça, inaugurando uma nova pauta de discussões entre aqueles países. Esse primeiro momento serviu para que as reticências mútuas fossem amainadas e a retórica da solidariedade continental começasse a ser utilizada, somando-se o fato de que o Brasil carecia do reconhecimento internacional do novo regime, buscando nos Estados Unidos - antes dos países europeus - a chancela para sua efetivação.

Obtido o reconhecimento, o que se viu especificamente no relacionamento entre os dois países foi o prolongamento dos debates percorridos na Conferência de Washington, quando foi discutido o acordo bilateral em 1891, a respeito da isenção de tarifas de importação e exportação de produtos. Mais uma vez agiu Salvador de Mendonça para que o acordo fosse assinado, sofrendo com as críticas e a desorganização do governo brasileiro diante do processo de negociação.

Para o diplomata, o bom relacionamento com os Estados Unidos no campo econômico poderia trazer bons frutos no campo político, leitura que fundamentou a intervenção norte-americana na Revolta da Armada entre 1893 e 1894. A despeito de uma disputa interna no País, Salvador de Mendonça, além de organizar uma nova esquadra nos Estados Unidos, negociou a intervenção armada no conflito pelos norte-americanos, que contribuíram para o término do movimento. Tal atitude foi severamente criticada pelos contemporâneos, que acusaram a diplomacia e o governo brasileiro de ofenderem a soberania do País, tutelando disputas domésticas no cenário internacional.

O ciclo de Salvador de Mendonça na diplomacia findou-se em 1898, depois da tentativa frustrada de remoção de Washington para 
Lisboa, a que se devem não somente as críticas da opinião pública à sua atuação, mas a disputa pela formulação de visões de mundo conectadas a grupos políticos. Tendo servido às presidências militares com tamanha polemização, a transição para os governos civis acabou por ceifar-lhe o cargo, à medida que um novo modus operandi no campo político era instaurado. Exonerado, Salvador de Mendonça passou a escrever e atacar os novos gestores (ou seja, Rio Branco) da política externa brasileira até 1913, quando faleceu no Rio de Janeiro.

A análise da trajetória de Salvador de Mendonça entre 1889 e 1898 e a leitura de sua correspondência diplomática permitem vislumbrar a efetivação da ideia de "republicanização" do campo político brasileiro, entendida como "americanização" por causa da aproximação com os Estados Unidos. Mendonça foi o agente maior dessa visão de mundo, sendo elogiado por segmentos republicanos e criticado por outros, como o movimento monarquista.

Essa visão de mundo insere-se como um traço do campo político brasileiro, engendrada em 1870 e colocada em prática a partir de 1889, no momento coincidente à ascensão econômica mundial dos Estados Unidos. O momento de síntese pelo qual atravessa o Brasil no período é oportuno para os norte-americanos, que não contemplam desinteressadamente as fragilidades de um país extenso geograficamente e com população crescente, certamente um amplo mercado consumidor de suas mercadorias.

O início dessa postura pró-americana se deu paralelamente à proclamação da República e, por causa das turbulências internas e externas ao País, não pôde ser assimilada em curto prazo, cabendo a Rio Branco e Joaquim Nabuco formularem com mais tenacidade as diretrizes da política exterior do País no certame continental. O ostracismo ao qual foi lançado Salvador de Mendonça após 1898 foi devido, sobretudo, a tais características e à disputa pela formulação de interpretações acerca dos fatos nos primeiros anos do novo regime. À historiografia coube reexaminá-las e compreender sua continuidade ou ruptura. 


\section{REFERÊNCIAS BIBLIOGRÁFICAS}

ALMEIDA, P. R. de. O estudo das relações internacionais no Brasil. São Paulo: Unimarco Editora, 1999. . Relações internacionais e política externa do Brasil. Porto Alegre: Editora da UFRGS, 2004.

ALONSO, Â. Idéias em movimento: a geração 1870 na crise do Brasil-Império. Rio de Janeiro: Paz e Terra, 2002.

ARIAS NETO, J. M. Império e República nos escritos monarquistas e na historiografia. Revista Eletrônica de História do Brasil (Juiz de Fora), v.1, n.2, p.53-65, dez. 1997. Disponível em: <http://www.ufff.br/ clionet/ rehb>. Acesso em: 12 dez. 2008.

A Revolta da Armada de 1893: um "fato" construído. In: OLIVEIRA, C. H. S. de et al. (Org.) A história na política e a política na história. São Paulo: Alameda, p.133-77, 2006.

AZÊDO, M. N. C. Imprensa republicana antes do 15 de Novembro. Niterói, 1975. Dissertação (Mestrado) - Universidade Federal Fluminense.

AZEVEDO, J. A. M. de. Vida e obra de Salvador de Mendonça. Rio de Janeiro: Ministério das Relações Exteriores, 1971.

BANDEIRA, L. A. M. Presença dos Estados Unidos no Brasil: dois séculos de história. Rio de Janeiro: Civilização Brasileira, 1973.

BENTO, C. M. A intervenção estrangeira durante a Revolta da Armada. Revista do Instituto Histórico e Geográfico Brasileiro (Rio de Janeiro), v.378-9, p.232-68, 1993. 
BERSTEIN, S. Cultura política. In: Para uma história cultural.

Lisboa: Estampa, p.349-63, 1998.

BETHELL, L. História da América Latina. São Paulo: Edusp; Brasília: Funag, 1997. v.4.

BOBBIO, N. et al. (Org.) Dicionário de política. Brasília: Editora UnB, 2007. $2 \mathrm{v}$.

BOEHRER, G. C. A. Da monarquia à República: história do partido republicano no Brasil (1870-1889). Rio de Janeiro, Ministério da Cultura e Educação, s. d.

BOURDIEU, P. O poder simbólico. Rio de Janeiro: Bertrand Brasil, 2003.

BUENO, C. A diplomacia da "consolidação": a intervenção estrangeira na Revolta da Armada. (1893/94). História (São Paulo), v.3, 1984. A República e sua política exterior: 1889 a 1902. São Paulo: Editora UNESP; Brasília: Fundação Alexandre de Gusmão, 1995.

. Relações internacionais: assimetrias nacionais e formação de blocos. In:VILLA, R. D.; MATHIAS, S. K. (Org.) Ensaios latino-americanos de política internacional. São Paulo: Aderaldo \& Rothschild, p.87-96, 2007.

BUENO, C.; CERVO, Amado L. História da politica exterior do Brasil. São Paulo: Ática, 1992.

CARDOSO, F. H. O Brasil republicano: estrutura de poder e economia (1889-1930). In: FAUSTO, B. (Org.) História geral da civilização brasileira. Rio de Janeiro: Bertrand Brasil, p.13-50, 1997.

CARONE, E. A Primeira República: texto e contexto. São Paulo: Difel, 1969.

A República velha: evolução política. São Paulo: Difel, 1971a.

A República velha: instituições e classes sociais. São Paulo: Difel, 1971b.

CARVALHO, J. M. A formação das almas. São Paulo: Companhia das Letras, 1990.

CASTRO, C. Os militares e a República: um estudo sobre cultura e ação política. Rio de Janeiro: Jorge Zahar Editores, 1995.

CASTRO, F. M. de O. História da organização do Ministério das Relações Exteriores. Brasília: Editora UnB, 1983.

CERVO, A. L. O Parlamento brasileiro e as relações exteriores: 1826-1889. Brasília: Editora UnB, 1981.

COSTA, E. V. da. Da monarquia à República: momentos decisivos. São Paulo: Brasiliense, 1994. 
DUROSELLE, J.-B. Todo império perecerá: teoria das relações internacionais. Brasília: Editora UnB; São Paulo: Imprensa Oficial do Estado, 2000.

EISENBERG, P. L. Guerra civil americana. São Paulo: Brasiliense, 1999.

FARIA, F. A. Arquivo de sombras: a privatização do Estado brasileiro nos anos iniciais da República brasileira. Rio de Janeiro: Sette Letras, 1996.

FAUSTO, B. (Dir.) História geral da civilização brasileira. São Paulo: Difel, t.III, v.1-2, 1977.

FERREIRA, G. N. O Rio da Prata e a consolidação do Estado imperial. São Paulo: Hucitec, 2006.

FERREIRA, J.; DELGADO, L. de A. N. (Orgs.) O tempo do liberalismo excludente: da proclamação da República à Revolução de 1930. Rio de Janeiro: Civilização Brasileira, 2003.

FONSECA JÚNIOR, G.; LEÃO, C. Relações internacionais. Brasília: Fundação Alexandre de Gusmão; São Paulo: Ática, 1989.

FREIRE, F. História da Revolta da Armada de 1893. Brasília: Editora UnB, 1982.

GOMES, A. de C. História, historiografia e cultura política no Brasil: algumas reflexões. In: Culturas políticas - ensaios de história cultural, história política e ensino de história. Rio de Janeiro: Mauad, p.21-44, 2005.

GONTIJO, R. História, cultura, política e sociabilidade intelectual. In: Culturas políticas - ensaios de história cultural, história política e ensino de história. Rio de Janeiro: Mauad, p.259-84, 2005.

GRAHAM, R. Grã-Bretanha e o início da modernização no Brasil. 1850-1914. São Paulo: Brasiliense, 1973.

HAHNER, J. E. Relações entre civis e militares no Brasil: 1889-1898. São Paulo: Pioneira, 1975.

HEINSFELD, A. A ruptura diplomática Brasil-Portugal: um aspecto do americanismo do início da República brasileira. In: SIMPÓSIO NACIONAL DE HISTÓRIA, 24, 2007.

HOBSBAWM, E. A era dos impérios. Rio de Janeiro: Paz e Terra, 1998.

HOLANDA, S. B. de. História geral da civilização brasileira. Rio de Janeiro: Bertand Brasil, v.II, 2005.

JANOTTI, M. de L. M. Os subversivos da República. São Paulo: Brasiliense, 1986.

LESSA, C. Nação e nacionalismo a partir da experiência brasileira. Estudos Avançados (São Paulo), v.22, n.62, p.237-56, 2008. 
LESSA, R. A invenção republicana: Campos Sales e as bases da decadência da Primeira República brasileira. São Paulo: Vértice, Revista dos Tribunais; Rio de Janeiro: Iuperj, 1988.

LIMA, O. O império brasileiro. São Paulo: Melhoramentos, 1927.

Memórias (estas minhas reminiscências...). Rio de Janeiro: José Olympio, 1937.

LYRA, H. História da queda do império. São Paulo: Companhia Editora Nacional, 1964.

MAGNOLI, D. O corpo da pátria: imaginação geográfica e política externa no Brasil. São Paulo: Editora UNESP, Moderna, 1997.

MALATIAN, T. Oliveira Lima e a construção da nacionalidade. Bauru: Edusc, 2001.

Brasil, Argentina e o pan-americanismo: de Monroe ao ABC. In: VILLA, R. D.; MATHIAS, S. K. (Orgs.) Ensaios latino-americanos de política internacional. São Paulo: Aderaldo \& Rothschild, p.43-54, 2007.

MATTOS, I. R. de. Do império à República. Estudos Históricos (Rio de Janeiro), v.2, n.4, p.163-71, 1989.

MENDONÇA, S. de. Marabá: romance brasileiro. Rio de Janeiro: Typ. Globo, 1875. Trabalhadores asiáticos. New York: Typ. do Novo Mundo, 1879.

MENDONÇA, S. de. Aspects of the brazilian rebellion. New York Times, 1894. Disponível em:<http://query.nytimes.com/mem/archivefree/ pdf?r=1\&res=9B04EFD81638E233A25757C0A9649C94659ED7CF \&oref=slogin>. Acesso em: 20 out. 2008.

A situação internacional do Brasil. Rio de Janeiro: Livraria Garnier, 1913.

de. Salvador de Mendonça: democrata do Império e da Republica. Rio de Janeiro: FNL, 1960.

MILZA, P. Política interna e política externa. In: RÉMOND, R. (Org.) Por uma história política. Rio de Janeiro: FGV, p.365-99, 2003.

MONTEIRO, H. M. Brasil República. São Paulo: Ática, 1986.

MORAES, E. de. 1871-1939: da monarquia para a República. Brasília: Editora UnB, 1985.

NABUCO, J. A intervenção estrangeira durante a revolta de 1893. São Paulo: Companhia Editora Nacional; Rio de Janeiro: Civilização Brasileira, 1939.

OLIVEIRA, C. H. S. de et al. (Orgs.) A história na política e a política na história. São Paulo: Alameda, 2006. 
OLIVEIRA, L. L. A questão nacional na Primeira República. São Paulo: Brasiliense, 1990.

PECEQUILO, C. S. A política externa dos Estados Unidos. Porto Alegre: Editora da UFRGS, 2003.

PESSOA, R. X. C. A idéia republicana através dos documentos. São Paulo: Alfa-Ômega, 1973.

PINTO, V. N. Balanço das transformações econômicas do século XIX. In: MOTA, C. G. Brasil em perspectiva. São Paulo: Difel, p.126-45, 1984.

PRADO, E. A ilusão americana. São Paulo: Brasiliense, 1958.

PRADO, M. E. (Org.) O Estado como vocação: idéias e práticas políticas no Brasil Oitocentista. Rio de Janeiro: Acess, 1999.

QUEIROZ, S. R. R. de. Os radicais da República. São Paulo: Brasiliense, 1986.

RÉMOND, R. Por uma história presente. In: (Org.) Por uma história política. Rio de Janeiro: FGV, p.13-36, $2003 \mathrm{a}$.

Do político. In: Por uma história política. (Org.) Rio de Janeiro: FGV, p.441-50, 2003b.

RENOUVIN, P.; DUROSELLE, J.-B. Introdução à história das relações internacionais. São Paulo: Difel, 1967.

RIBEIRO JÚNIOR, J. O Brasil monárquico em face das repúblicas americanas. In: MOTA, C. G. Brasil em perspectiva. São Paulo: Difel, p.146-61, 1984.

RODRIGUES, J. H. Interesse nacional e política externa. Rio de Janeiro: Civilização Brasileira, 1966.

RODRIGUES, J. H.; SEITENFUS, R. A. S. (Orgs.) Uma história diplomática do Brasil: 1531-1945. Rio de Janeiro: Civilização Brasileira, 1995.

SANTOS, L. C. V. G. O Brasil entre a América e a Europa: o império e o interamericanismo (do Congresso do Panamá à Conferência de Washington). São Paulo: Editora UNESP, 2004.

SCHOULTS, L. Estados Unidos: poder e submissão: uma história da política norte-americana em relação à América Latina. Bauru: Edusc, 2000.

SECKINGER, R. O Estado brasileiro e a política externa no século XIX. Dados, n.19, p.111-3, 1978.

SEITENFUS, R. Por uma nova política brasileira. Porto Alegre: Livraria do Advogado, 1994.

SILVA, C. Floriano Peixoto: o consolidador da República. São Paulo: Edagert, 1963. 
Quintino Bocaiúva, o patriarca da República brasileira. Brasília: Editora UnB, 1983. (Coleção Temas brasileiros, 32).

SILVA, J. L. W. da. A historiografia das relações internacionais do Brasil. Revista do Instituto Histórico e Geográfico Brasileiro (Rio de Janeiro), v.378-9, p.154-78, 1993.

SILVA, K. V. Dicionário de conceitos históricos. São Paulo: Contexto, 2006.

SILVEIRA, R. M. G. Republicanismo e federalismo: um estudo da implantação da República brasileira (1889-1902). Brasília: Senado Federal, 1978.

SIRINELLI, J. F. Os intelectuais. In: RÉMOND, R. Por uma história política. Rio de Janeiro: FGV, p.231-70, 2003.

SOUTO MAIOR, L. A. P. O pan-americanismo e o Brasil. Revista do Instituto Histórico e Geográfico Brasileiro (Rio de Janeiro), v.378-9, p.331-49, 1993.

SOUZA, M. do C. C. de. O processo político-partidário na Primeira República. In: MOTA, C. G. (Org.) Brasil em perspectiva. São Paulo: Difel, p.162-226, 1984.

VINHOSA, F. L. T. As relações Brasil-Estados Unidos durante a primeira República. Revista do Instituto Histórico e Geográfico Brasileiro (Rio de Janeiro), v.378-9, p.280-94, 1993. 


\author{
SOBRE O LIVRO \\ Formato: $14 \times 21 \mathrm{~cm}$ \\ Mancha: 23,7 x 42,5 paicas \\ Tipologia: Horley Old Style 10,5/14 \\ 1a edição: 2009 \\ EQUIPE DE REALIZAÇÃO \\ Coordenação Geral \\ Marcos Keith Takahashi
}


CULTURA

ACADÊMICA

Editona 